\title{
إستراتيجية هقترحة لتطوير برنامج التربية العملية بكلية التربية جاهعة الطائف في ضوء بعض الاتجاهات العالمية المعاصرة
}

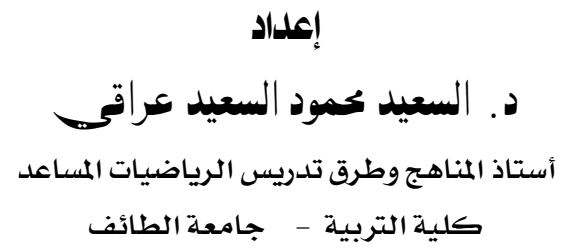

مجلة بحوث التزبية النوعية - جامعة المنصورة

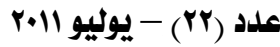




$$
\text { د. إعداد السعيد محمود السعيد عراقيتـ }
$$

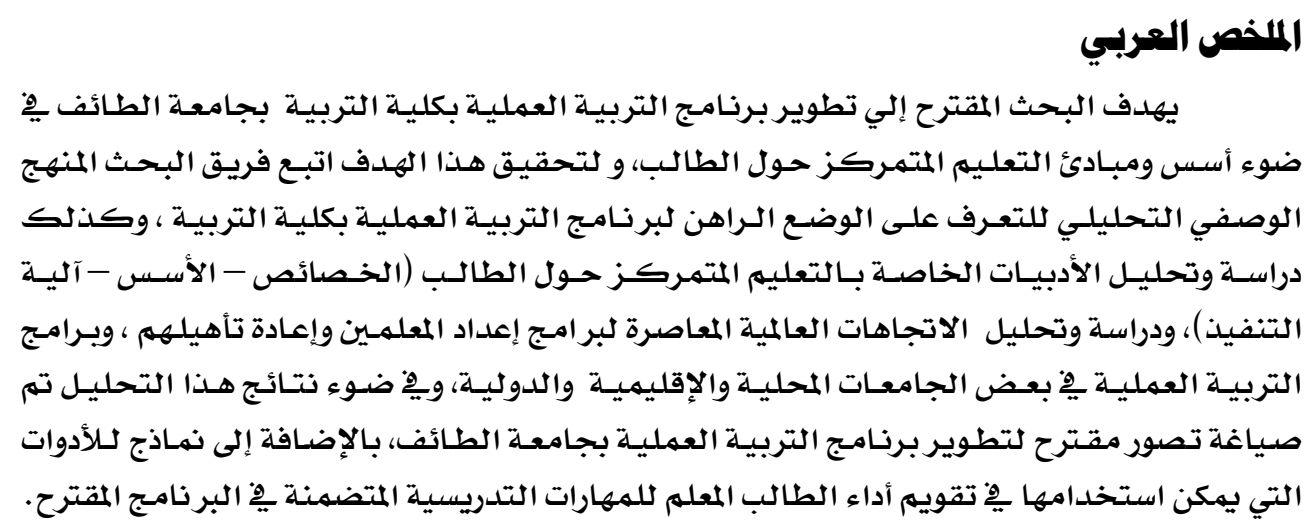

\section{Abstract}

The present research aims at developing practice teaching program at Taif University in the light of the established principles of Learnercentered education. To achieve the objectives of the research team adopted a descriptive (analytical) methodology. Documentary, field related and literature data were collected, classified and analyzed. Accordingly, a reform strategy was proposed. The proposed strategy is intended to reflect the theoretical principles and foundations of learner-centered education. It consists of a series of events on how to design and implement active, collaborative, and cooperative learning and other inquiry-based teaching and assessment activities and techniques. It provides examples for student teachers training through involving them in co-operative tasks and projects with their fellow student teachers and supervisors. It also provides sample evaluation tools for on situ observation and evaluation.

أستاذ المناهج وطرق تدريس الرياضيات المساعد - كلية التربية - جامعة الطائف 


\title{
إستراتيجية هقترحة لتطوير برناهج التربية العملية
}

\section{بكلية التربية جامعة الطائف في ضوء بعض الاتجاهات العالمية المعاصرة}

\author{
إعداد \\ د. السعيد محمود السعيد عراقيـ
}

\section{همدمهة الدراسة:}

إن أهمية إعداد المعلمـين ِِِ كليات التربية لم يؤكدها المختصون يِّا التربية والتعليم فقط،

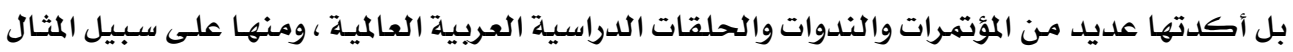

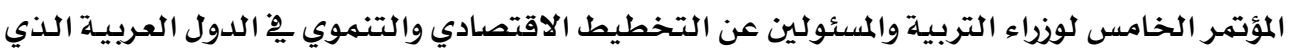

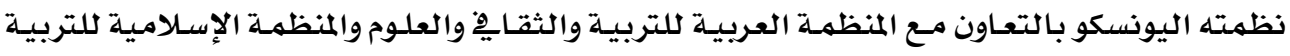

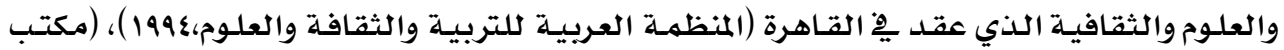

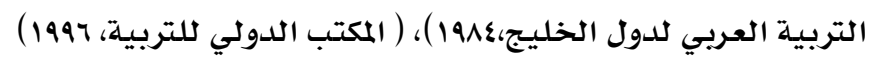

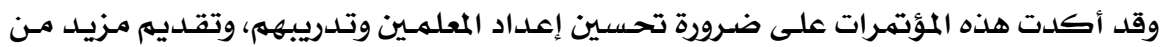

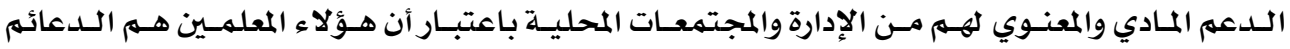

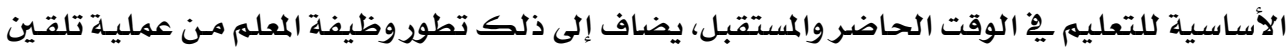

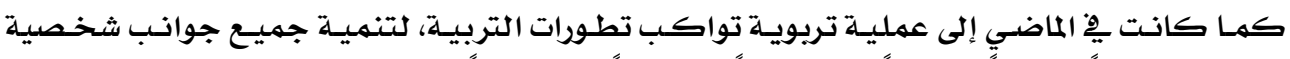

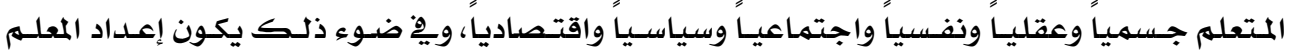

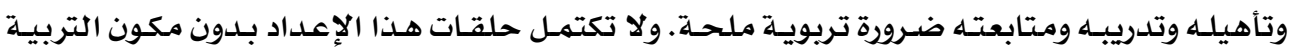

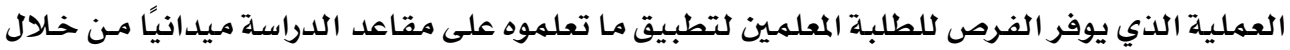

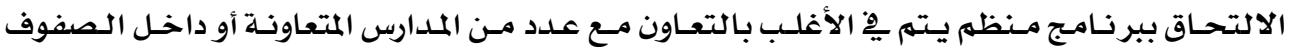

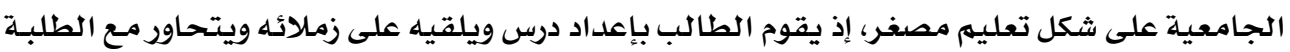

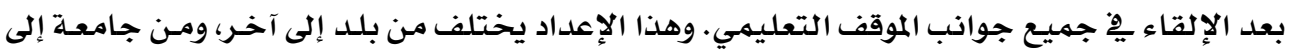

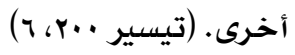

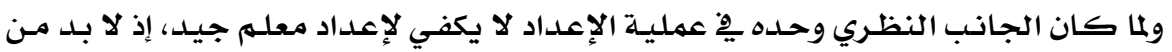

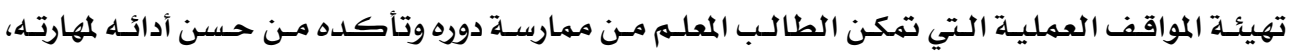

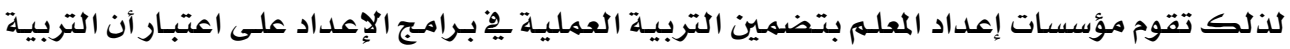

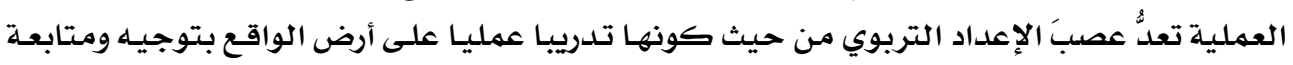

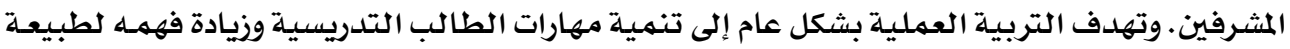

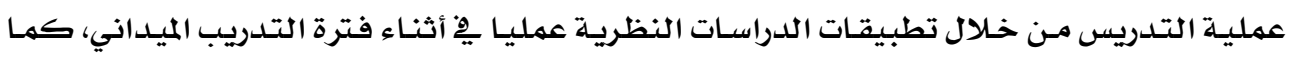

أستاذ المناهج وطرق تدريس الرياضيات المساعد - كلية التربية - جامعة الطائف 
تهدف إلى معاونة الطالب على التكيف مـع المواقف المختلفة التي تواجهه يِ أثناء عمله وإكسابه قدرا

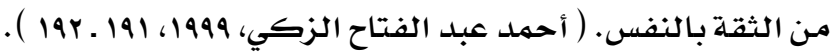

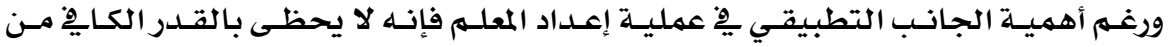

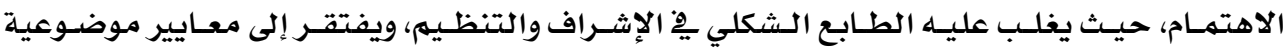

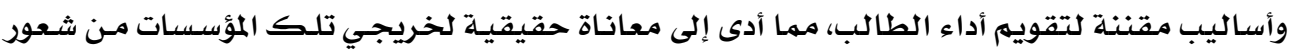

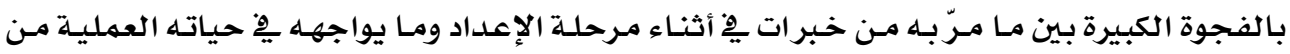

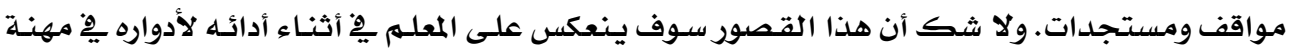

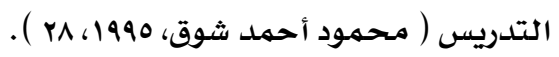

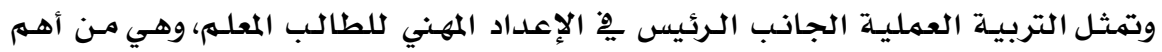

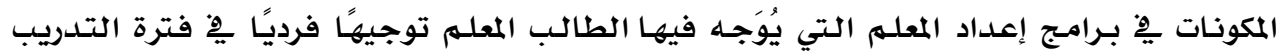

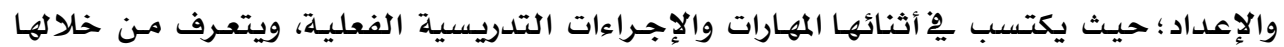

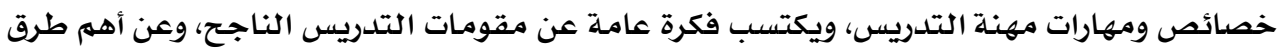

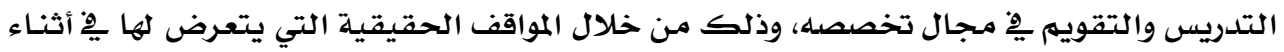

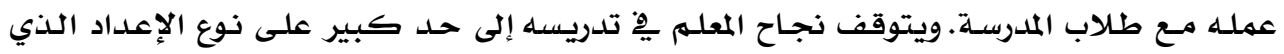

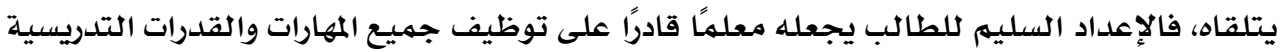

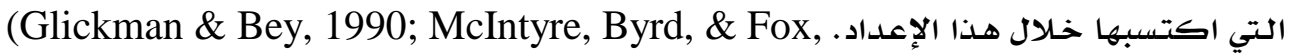

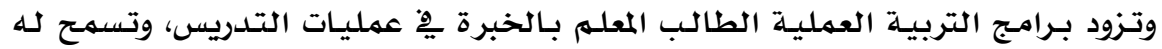

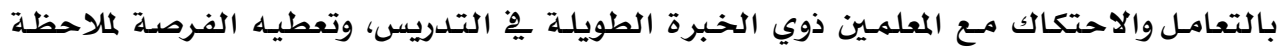

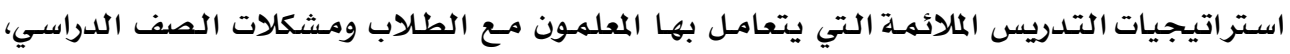

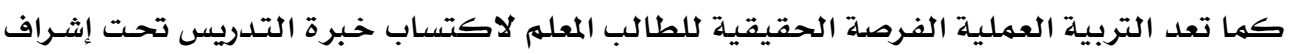

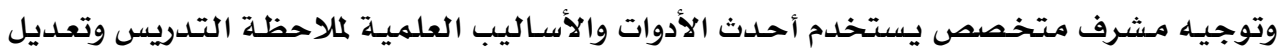

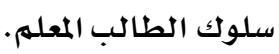

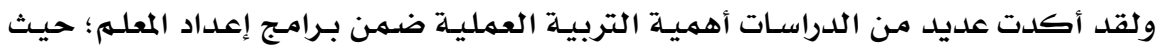

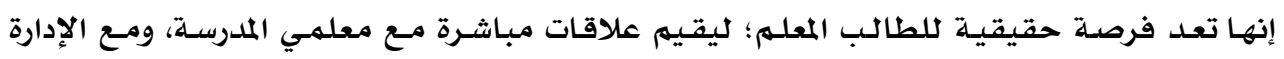

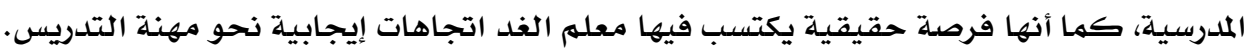

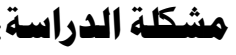

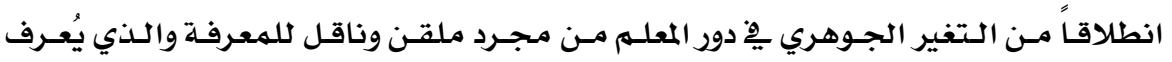

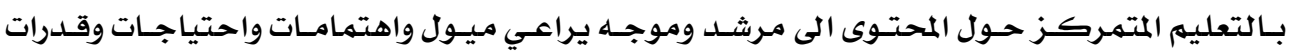

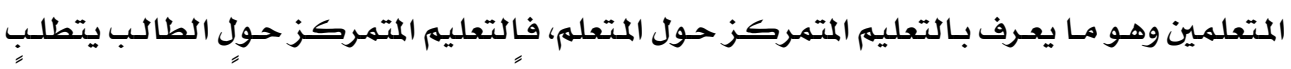

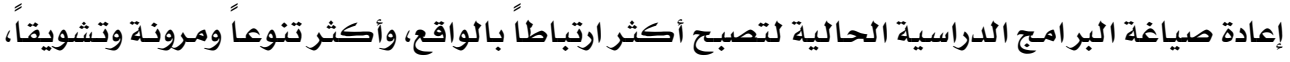




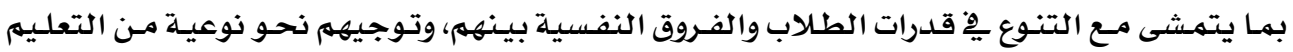

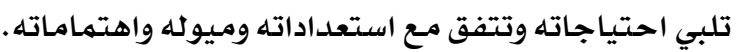

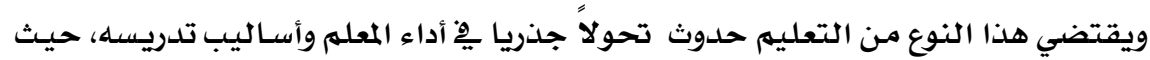

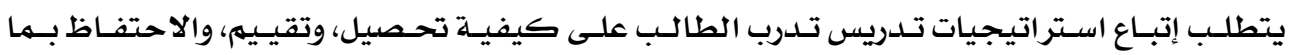

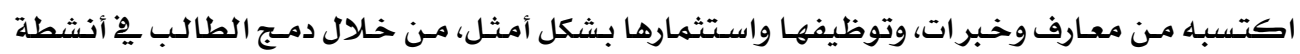

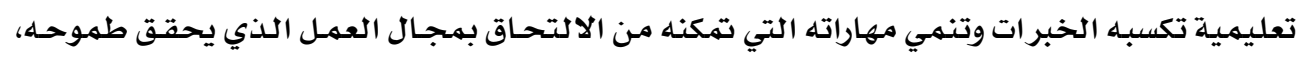

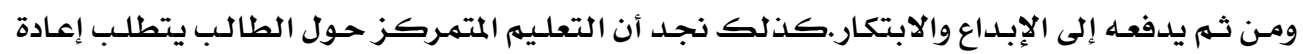

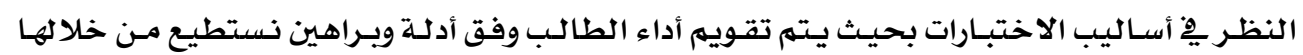
التعرف علي نقاط القوة والضعف يْ أداء الطالب. Huba \& Freed ,2000; McCombs \& Whisler ,1997; O'Banion ,1997 ;

Weimer, M. G. 2002)

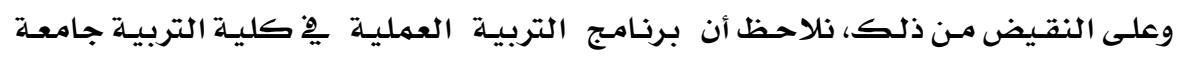

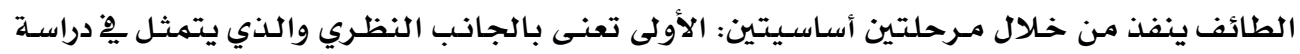

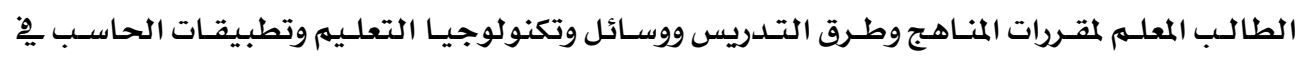

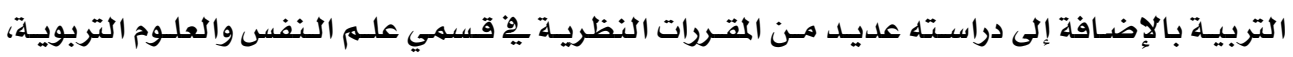

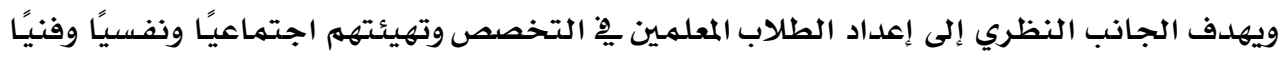

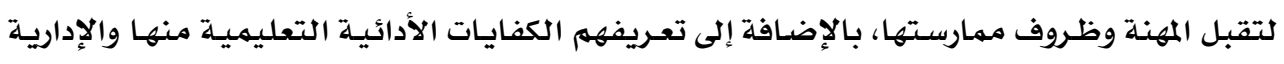

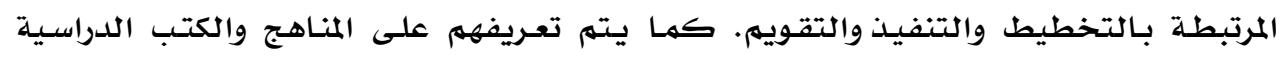

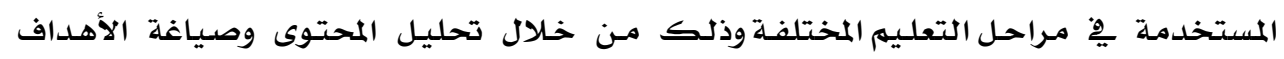

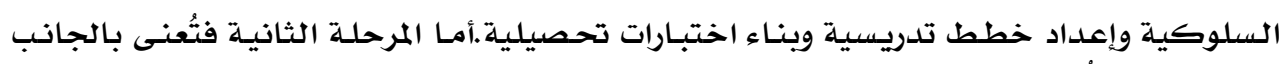

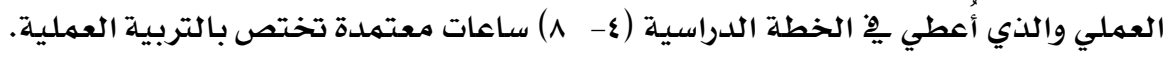

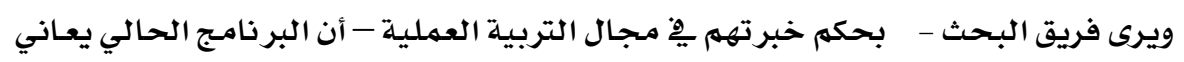

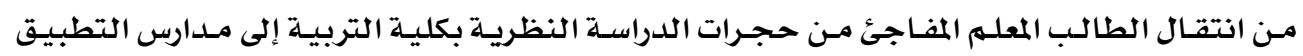

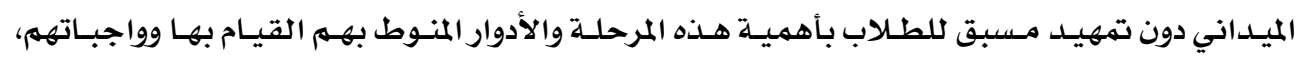

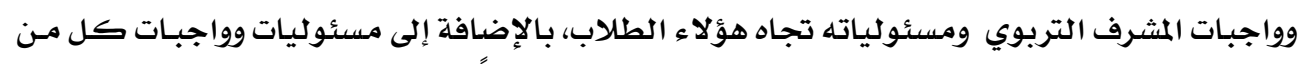

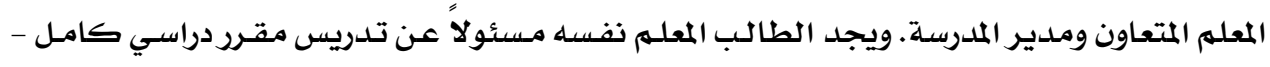

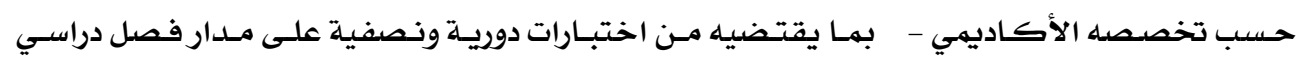

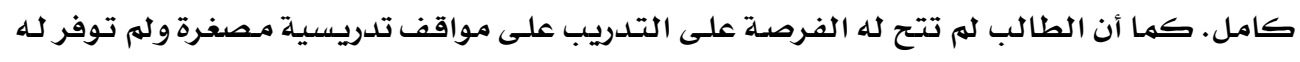

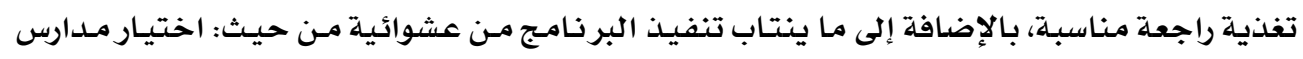

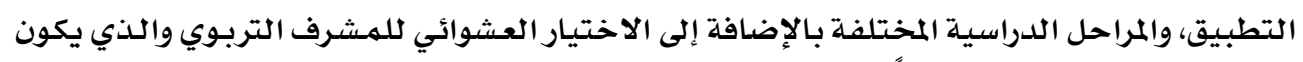

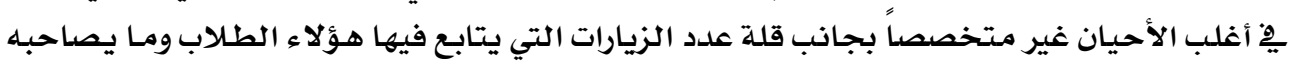

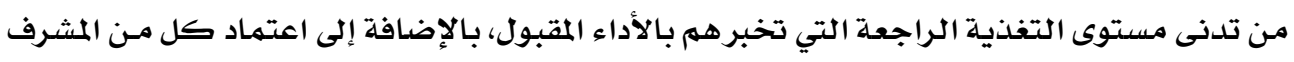


التربوي والمعلم المتعاون ومدير المدرسة على أدوات تقويم غير مقننة ( ه ) والتي تعطي نتائج غير موثوقة

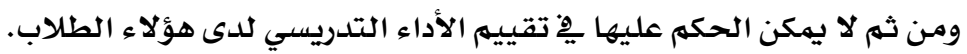

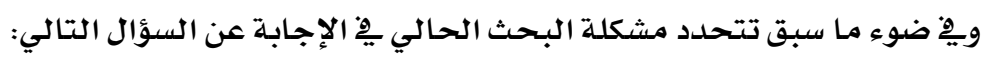

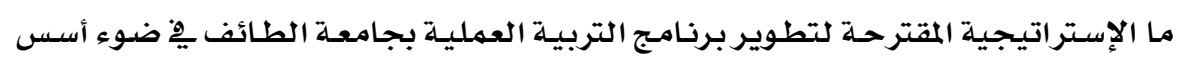

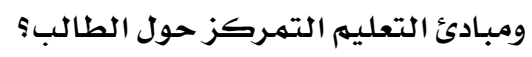

$$
\begin{aligned}
& \text { ويتفرع عن السؤال السابق التساؤلات التالية؟ }
\end{aligned}
$$

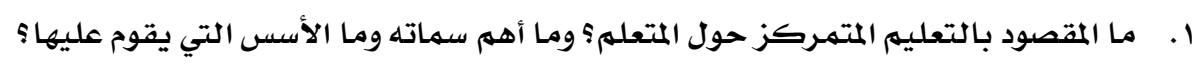

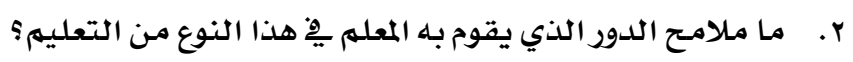

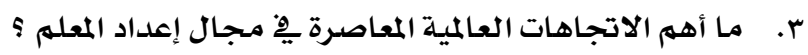

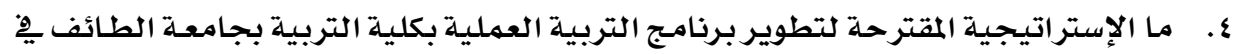

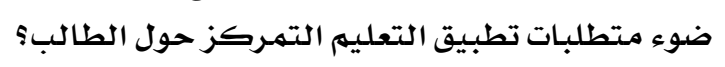

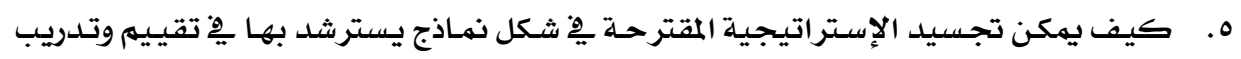

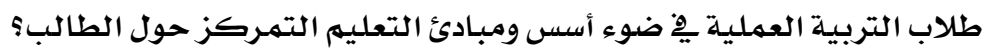

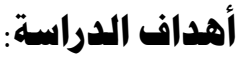

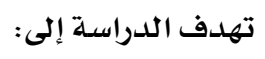

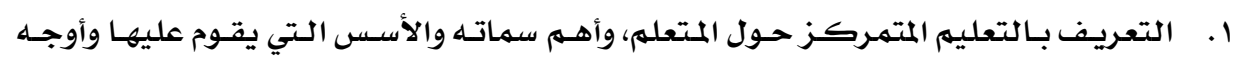
اختافه عن التعليه التقليدي.

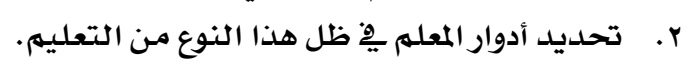

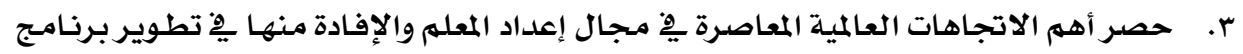

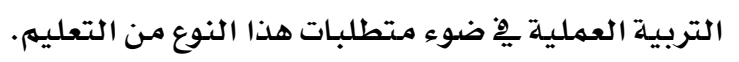

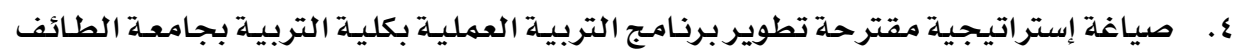

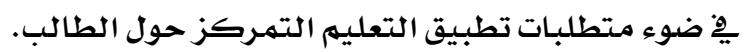

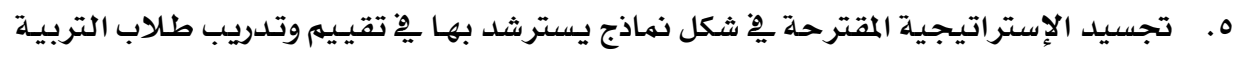

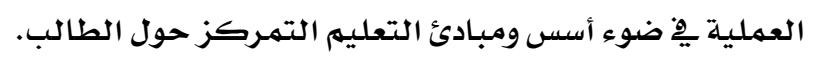

\section{أهمية الدراسة:}

$$
\text { من المتوقع أن تفيد الدراسـة ِِِّ النواحي الآتية: }
$$

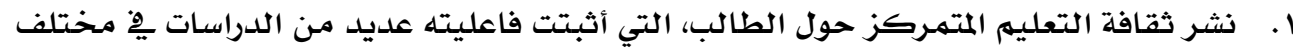

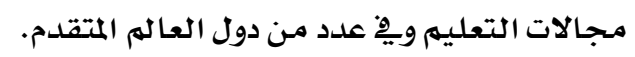

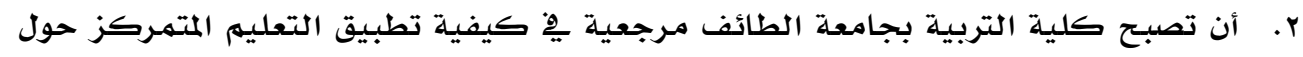

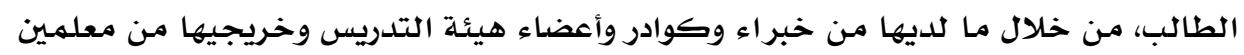

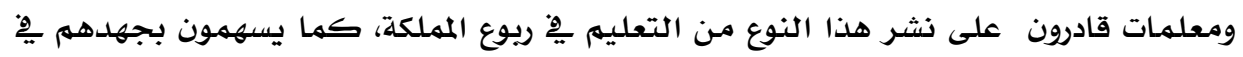


معاونة زملائهم مِّ باقي مؤسسات التعليه العالي من أجل تطوير أسلوب إدارة برنامـج التربية

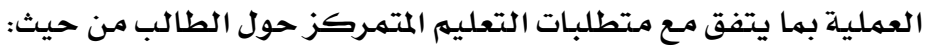

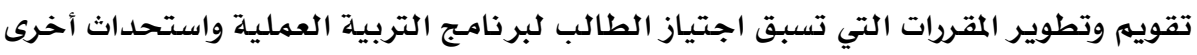

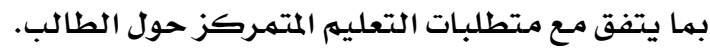
تقويم وتطوير بيئة التعلهم الصفية لتدريب الطلاب وتهيئتهم لاجتياز برنامـج التربية العملية

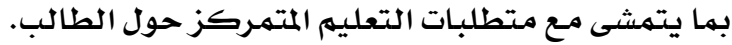

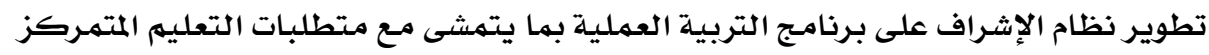
حول الطالب. تطوير نظام تقويم طلاب التربية العملية بما يتمشى مـع متطلبـات هذا النوع من التعليم. الإطار النظري والدراسات السابقة: يعرض الجزء التالي للإطار النظري للدراسة والدراسات السابقة بهدف: - - التعريف بالتعليم المتمركز حول المتعله، وأهم سماته وخصائصه والأسس التي يقوم عليها.

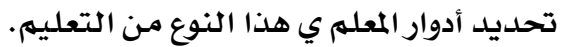

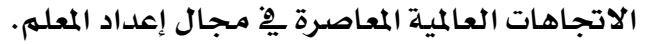

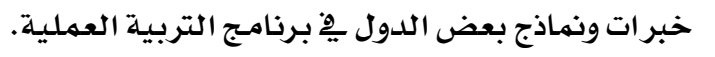

أولاً: التعليه المتمركز حول المتعله،(مفهومه، وأهم سماته وخصائصه والأسس التي يقوم عليها). تعريف التعليم المتمركز حول المتعلم (الطالب):

Arizona Faculties Council (AFC), يرى مجلس أعضاء هيئسة التدريس بأريزونا

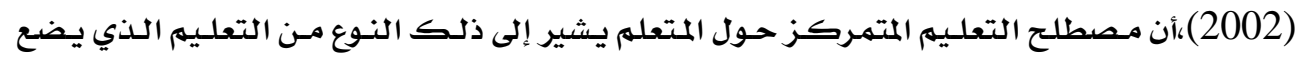

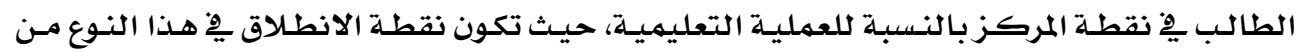

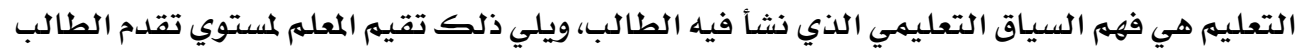

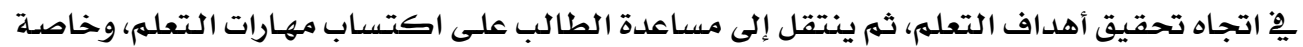

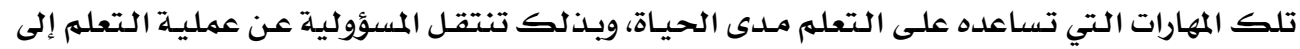

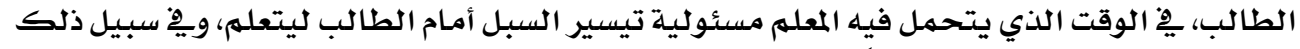

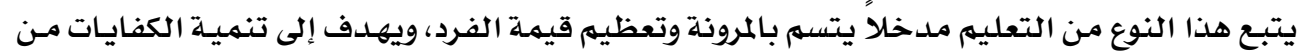

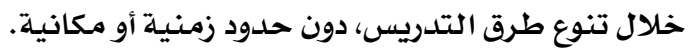

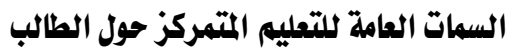

مoِ ضوء ما كتبه كل من Norman Spohre (1996); Grunert (2000);Weimer (2002); Ludmerer (2004); Jeffrey (2009); Flint (2010). المتمـركز حول الطالب يمكن تلخيصها فيما يلي: 
ا. اعتبار الطلاب شركاء أساسين يِّ العملية التعليمية، حيث إنهم يشكلون مصدرا مهمـا للأهـداف

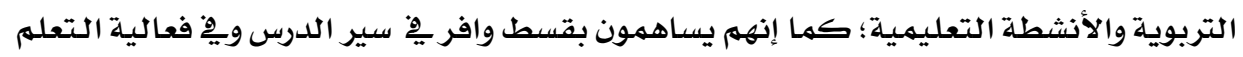
ونواتجه، ويتحملون جزءا كبيرا من مسؤولية تعلمهـهم.

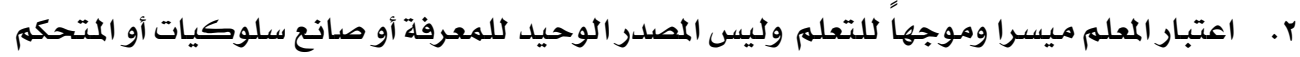
مِِّ جميع مجريات الفصل. r. اعتبار الفصل مجالا للتفاعل والعمل التعاوني من أجل التعلم والنمو وليس لتلقي دروس نهطية

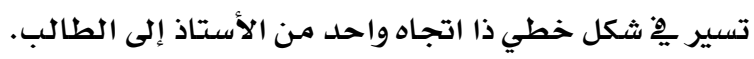

أسس ومبادئ التعليه المتهركز حول المتعلم:

; McCombs \& Whisler, (1997); Ohashi. \& Ohashi (1993) طبقاً ذا ذكره O'Banion (1997); Weimer (2002); Bender (2003); Mccombs \& Vakili الأ (2005); Uribe. (2008); Normandy (2009) فان التعليه المتمركز حول المتعلم يقوم على الأسس والمبادئ التالية:

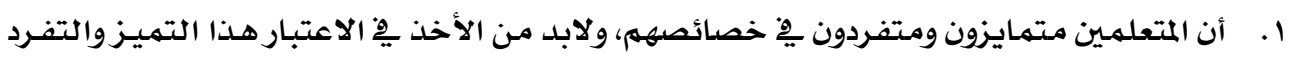

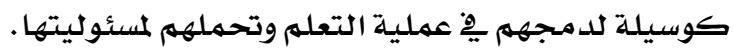

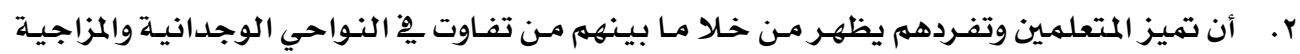

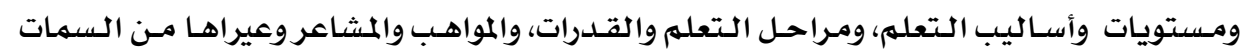

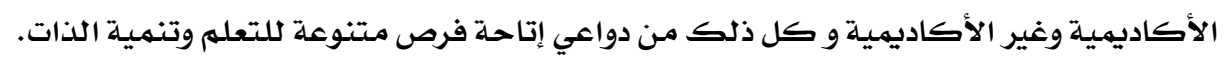

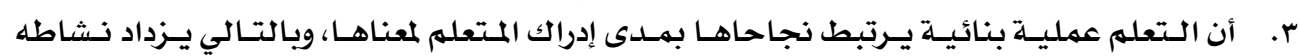

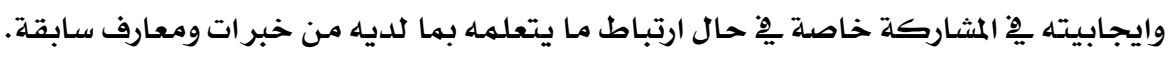

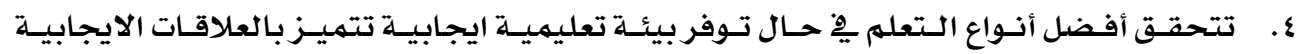

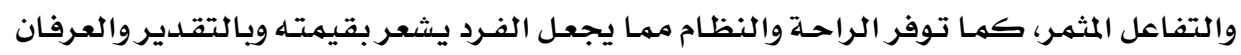

$$
\text { والاحترام الذي يستحقهم. }
$$

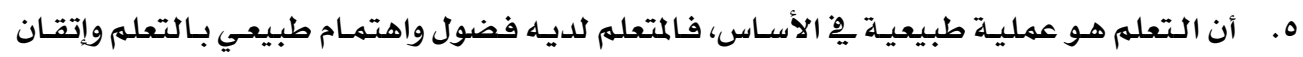

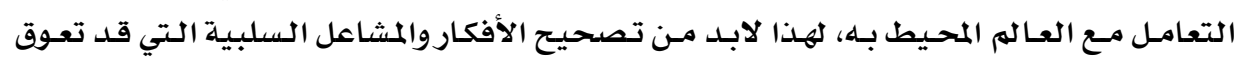

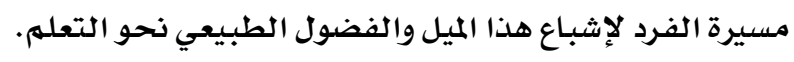

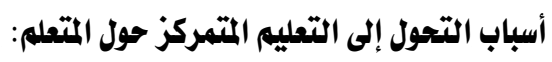
يرى (1997) (أن مـن أسباب التحول إلى التعليهم المتمـركز حول المتعله:

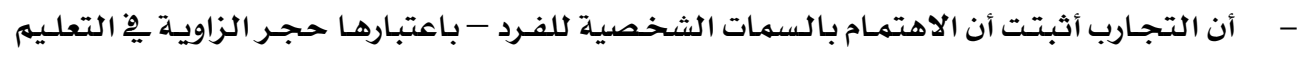

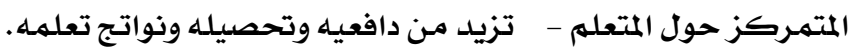




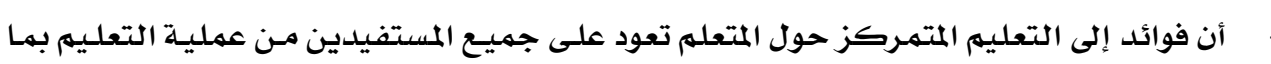

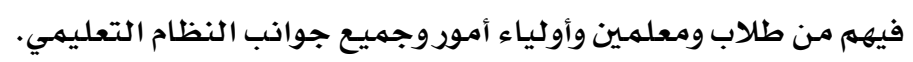

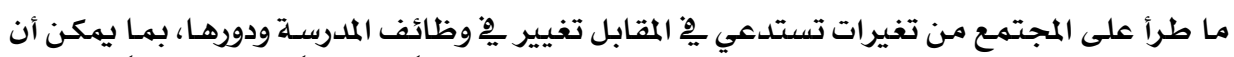

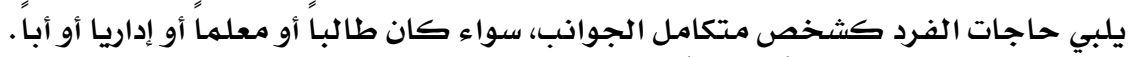

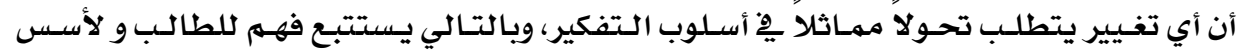

$$
\text { ومبادئ عملية التعله. }
$$

\section{الفرق بين التعليم التقليدي والتعليم المتمركز حسـول الطالب}

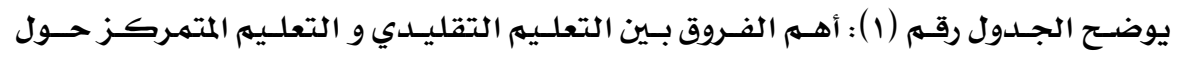

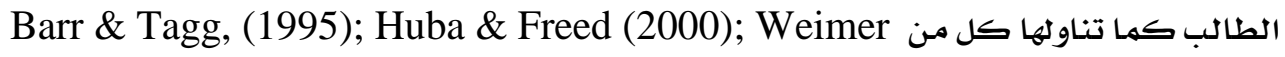
:Normandy (2009).2003(2002); Brown ( 2003)

جدول (1) ) أهم الفروق بين التعليم التقليدي والتعليم المتمركز حسول الطالب.

\begin{tabular}{|c|c|c|}
\hline التعليم المتمركز حــول الطالب & التعليم التقليدي & المجـالات \\
\hline 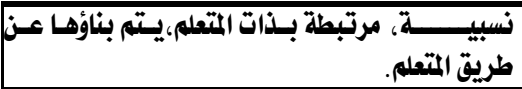 & المتعلم. ــــــــ، تعادل الحقيقة، ذات وجود مسبق مستقل عـز & المــــرفـة \\
\hline 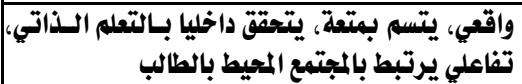 & ثصابت من المعلم إلى الطالب من الخارج، خطي يسير في خط واحسل & التعـــــــم \\
\hline الطالب والمهام المنجزة، يحرك نشاط الجماعة، وسيط بيز & 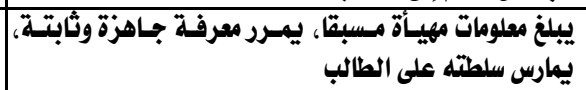 & المُــــلم \\
\hline 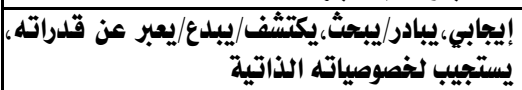 & لطلبي، يستمع/يكتب/يجيب، يخزن ويسترجع المعرفة، يخضع & المتعلم \\
\hline 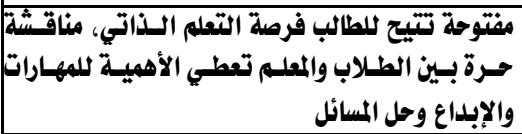 & 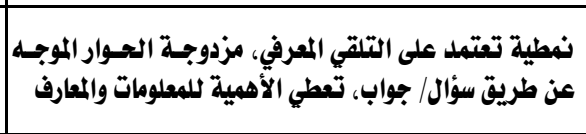 & الطــريقــة \\
\hline داخلية ترتكز على ميول وحاجات الطلاب & 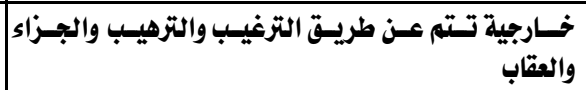 & الحوافز \\
\hline كل طالب يسير وفق إيقاعه الخاص به. & والإيقاع على جميـع الطـلاب أن يتعلمـوا بــنفس الـسرعة & إيقاع التعلم \\
\hline
\end{tabular}

سمات الفصل اللدراسي في التعليه المتهركز حول الطالب:

يتميز الفصل الدراسي يِ التعليم المتمبركز حول المتعلم بعدة سمات تم تلخيصها فيما يلي

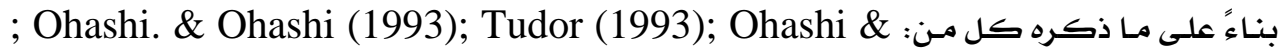
Ohashi (1993); Altan \& Trombly (2001); Hewett (2003); Doyle (2007); : Normandy (2009) Brown (2003).

1. مراعاة التنوع ٌِِ الخصائص والفروق الفردية ِِّ تنظيم وتسيير العمل داخل الفصل الدراسي. 


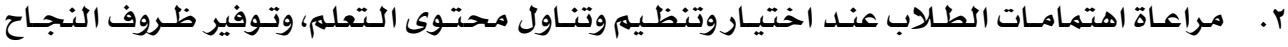
وتهكينهم من التعبير والنمو وكذلك بتكييف التدريس مـع مهارات الطلاب وخصائصهاتهم.

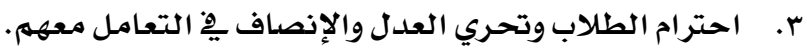

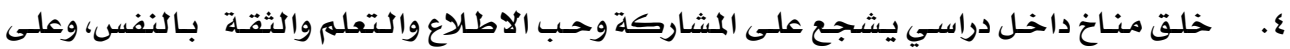

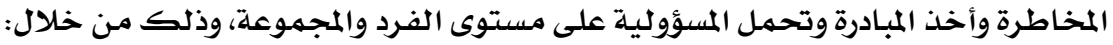

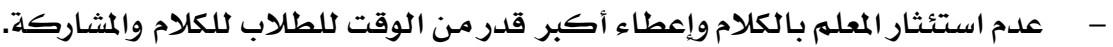

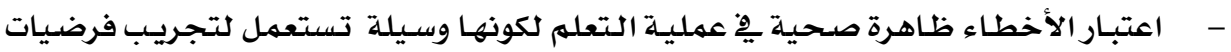

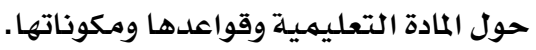

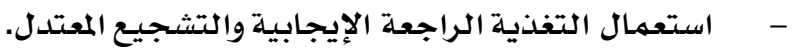

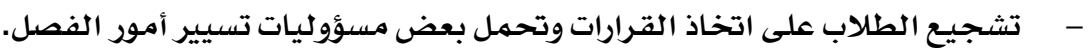

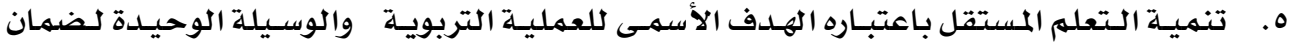

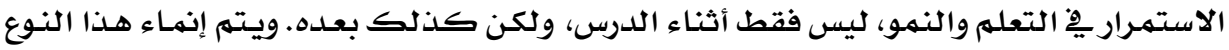

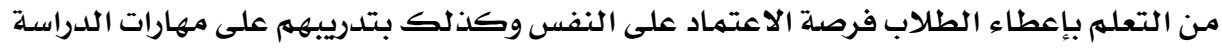
(Study Skills)

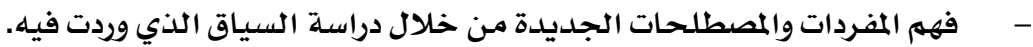

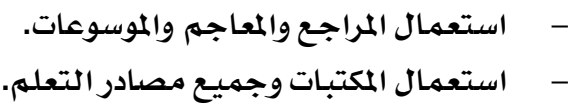

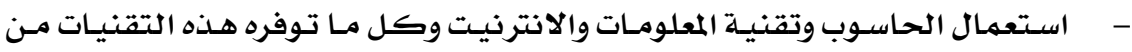

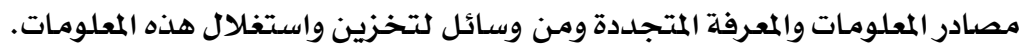

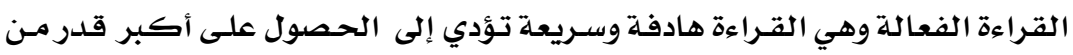

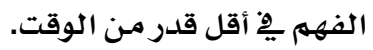

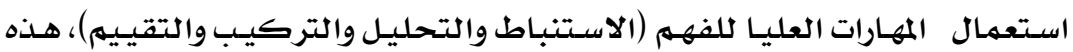

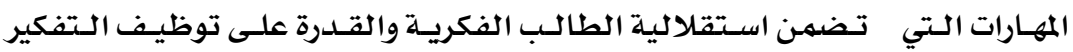

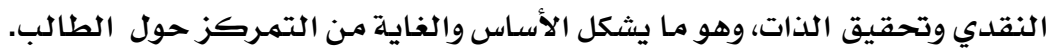

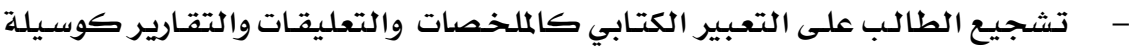
للتعلم. تشجيع. - - تشجيع العمل الدراسي المستقل مِّ توزيع وقت الواجبات ومراجعة الدروس. - تشجيع الطالب على تلخيص وعرض النقاط الأساسية للموضع.

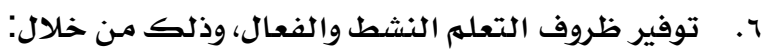

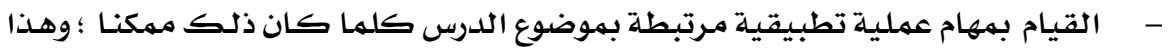

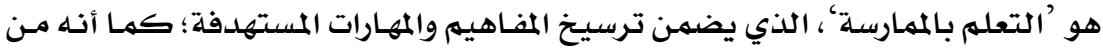

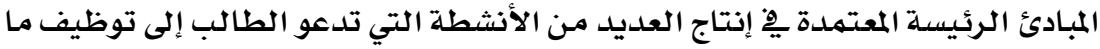




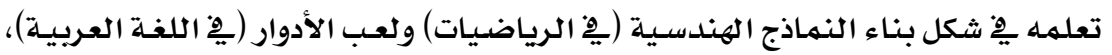

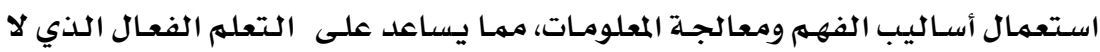

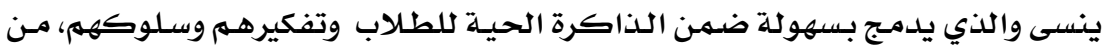

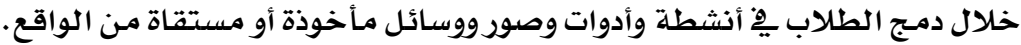

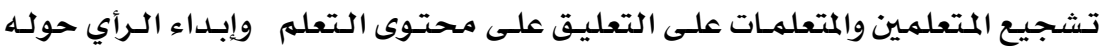
وريطه بالحياة الشخصية.

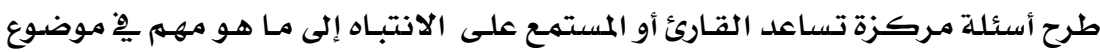

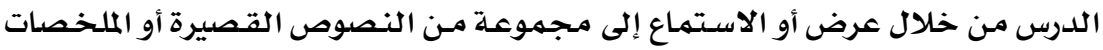

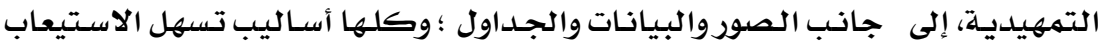

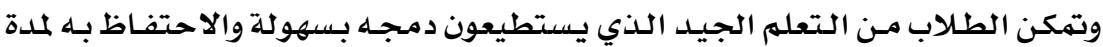

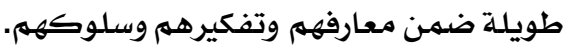
أدوار المعلم في التعليم المتمركز حول الطالب معارفي وتفره

Ohashi. \& Ohashi (1993); Tudor (1993); Altan \& فهـ يرى كل مـن فإن هـذا Trombly (2001); Hewett (2003); Doyle (2007); Normandy (2009).

النوع وهذا من التعليهم يضع على عاتق المعلم ما يلي:

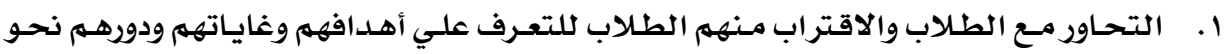

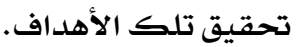

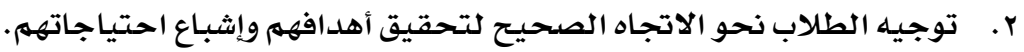

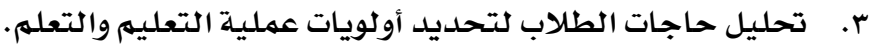

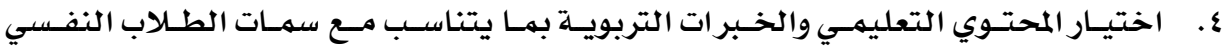

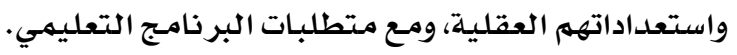

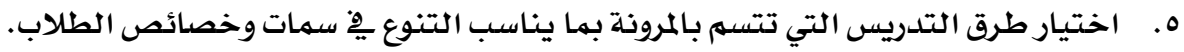

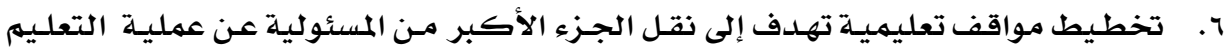

$$
\text { والتعلهم إلى الطالب ليصبح أكثر ايجابية. }
$$

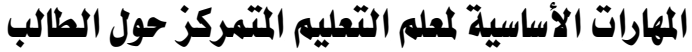

Oيرى كل مسن . Ohashi. \& Ohashi (1993); Tudor (1993); Weimer. (2002)

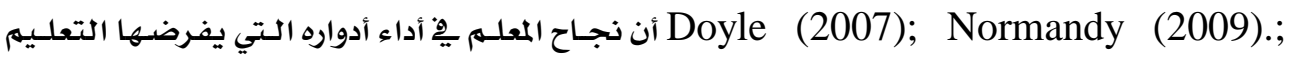

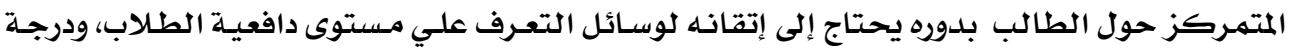

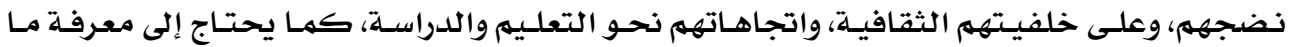

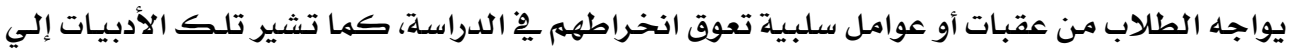


أن نجـاح المعلـم مِِّ أداء أدواره مـن خـلال هـذا النـوع مـن التعلـيم فانـه بحاجـة لثلاثـة حـزم مـن المهارات الأساسية كما يلي:

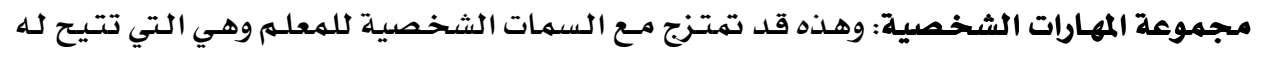

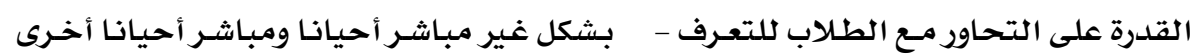

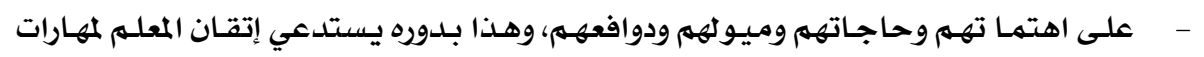

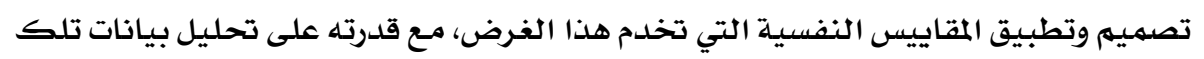

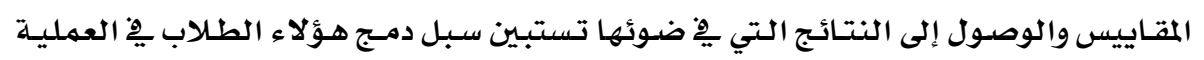

$$
\text { التعليمية بشكل أكثر ايجابية وفاعلية. }
$$

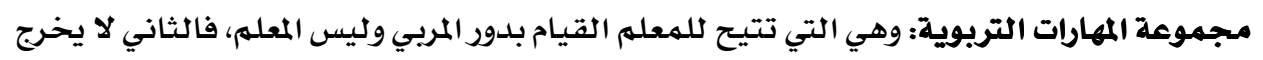

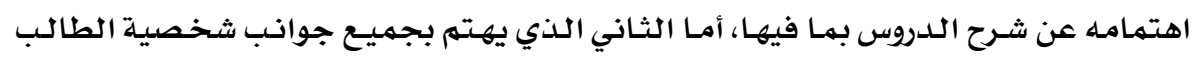

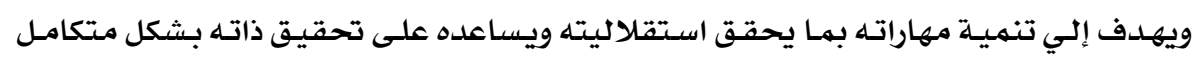

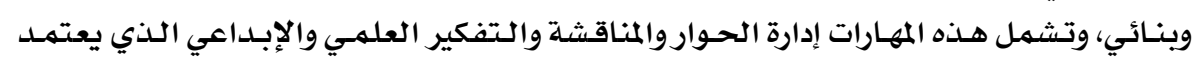

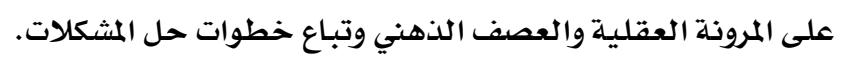

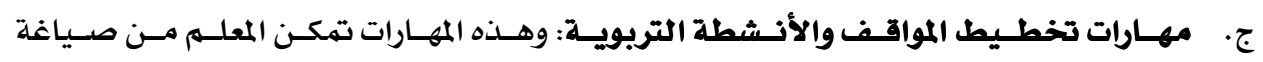

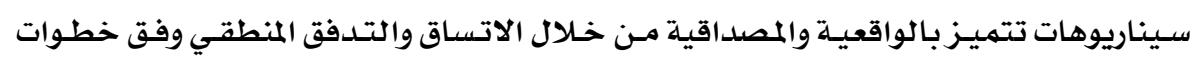

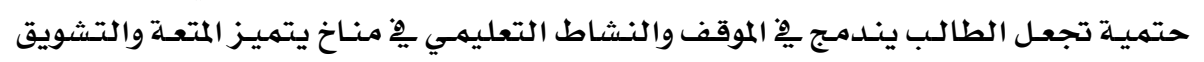

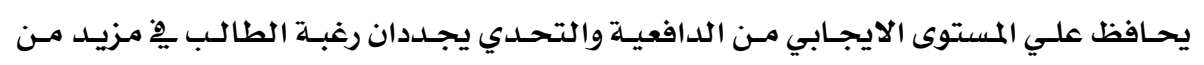
التعلهم. د. مهارات تقـويم الأداء الطلابـي: وهـذه المهارات تعكس مـدى إدراك المعلـم لحقيقــة أن كل مـن

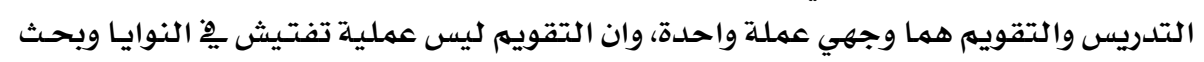

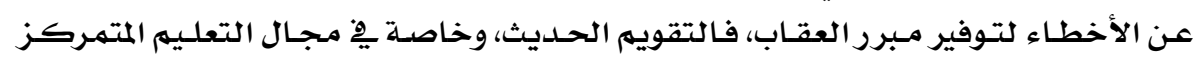

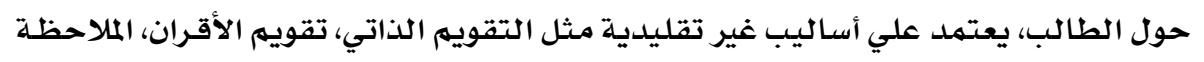

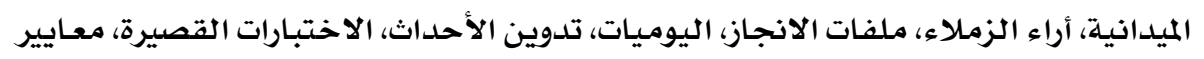

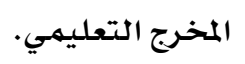

\section{ثاثياً:الاتجاهات العالمية المعاصرة في مجال إعداد المعلم:}

تتعدد توجهات إعداد المعلهم وكيفية تطوير وأداءه، ومن أهمها ما يلي:

\section{ا. إعداد المعلم في ضوء الكثايات: Competency-Based Teacher Education}

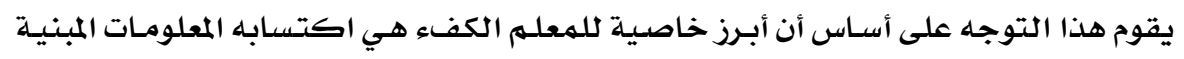

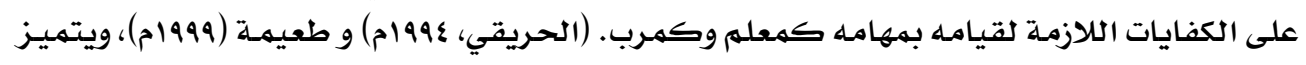

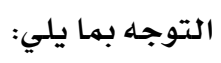
- - ل 
يعد من التوجهات التي تسههم فِّ بنـاء معايير تقـرب الطالب/المعلـم إلى أقصى درجـة ممكنـة

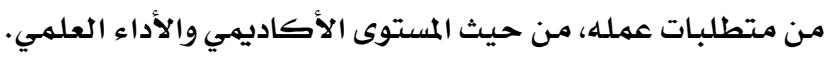

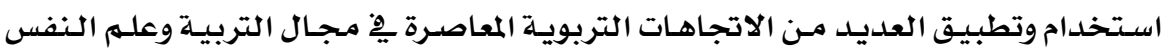

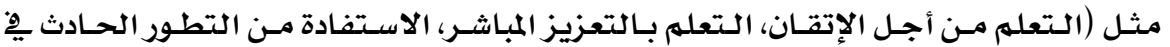
مجال تقنيات التعليه، الاستعانة بأساليب التقويم المختلفة الانقة).

\section{rـ إعلداد المعلم على أساس المهارات: Skill-based Teacher Education}

ظهر هذا التوجه هِّ السبعينيات من القرن الماضي نتيجة مـا تدعو إليـه التغيرات العالميـة مـن

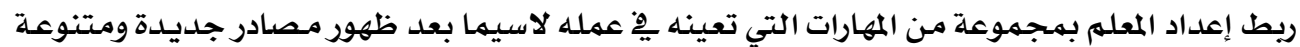

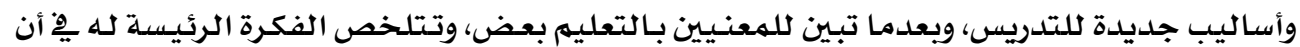

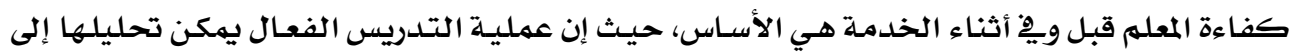

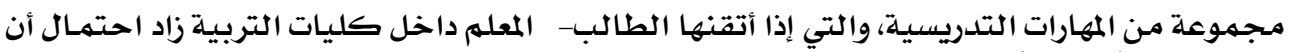

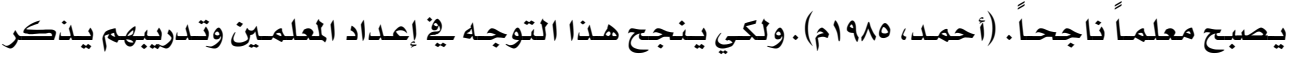
(Kipplle, 1975)

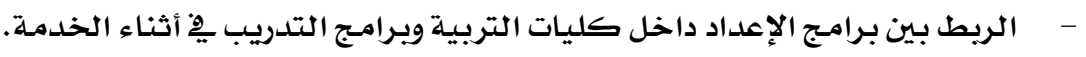

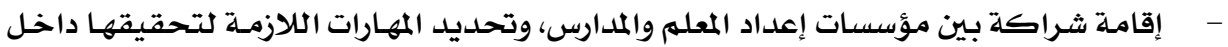
برامـج الإعداد.

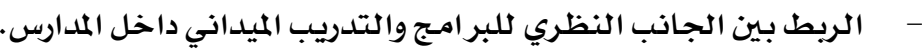

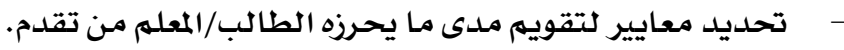

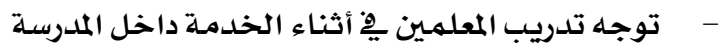

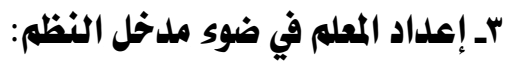

يستند هذا التوجه إلى نظرية النظم العامـة المطبقة يف التفكير والتخطيط والبحث العلمي؛

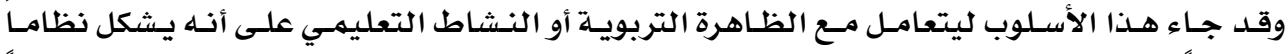

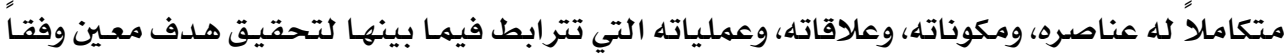

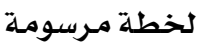

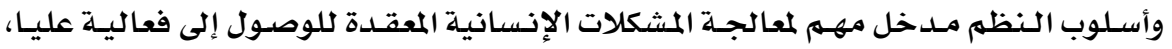

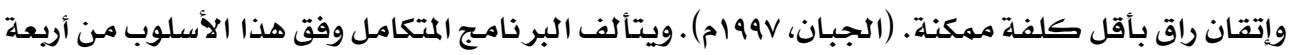
أجزاء مهمـة هي :

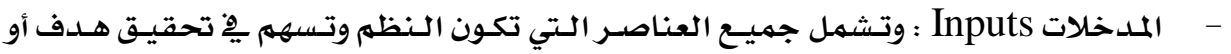

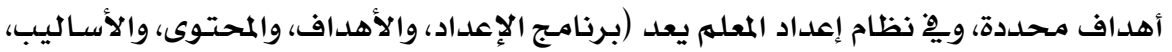

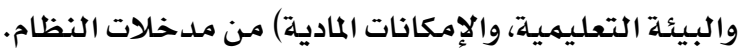


العمليـات Processes : وهـي سلسلـة مـن الإجـراءات والتفـاعلات النشطة الـتي تحسدث بـين

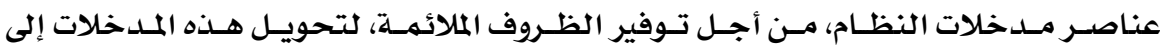
مخرجات يراد تحقيقها.

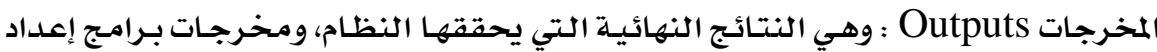

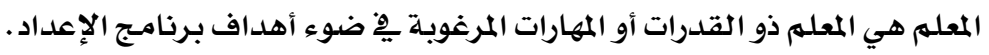

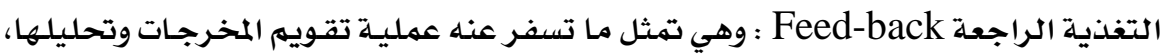

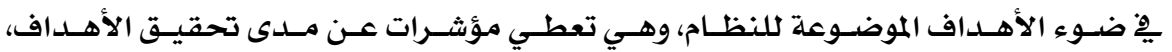

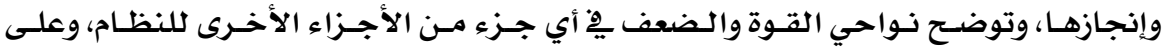

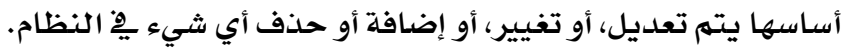

\section{كـ إعداد المعلم وفق معايير الجودة والاعتماد:}

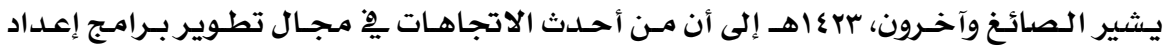

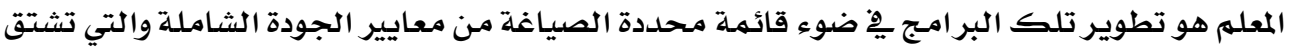

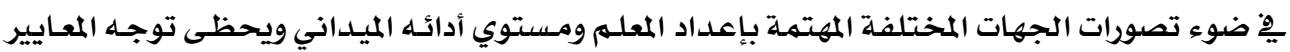

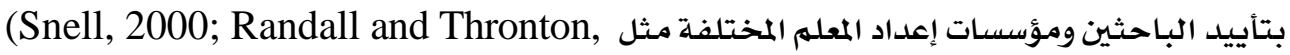
2001; American Council on the Teaching of Foreign Languages (ACTFL), 2002, McCloskey et al., 2003; Glass, 2004 ; and Borman and Kimball, 2005; Morton, 2005).

ِِّْ مجال إعداد وتدريب المعله يساعد على: تبنى فلسفة واضحة المعالم لإعداد المعلم. صياغة وتحديد أهداف برنامـج إعداد المعلم صياغة إجرائيـة قابلة للقياس. تقرير أنسب الموضوعات التعليهيـة لبرنامه إعداد المعله. اقتراح أفضل طرق التعليه والتعلهم عند تنفيذ البر نامـج. تحديد طرق ووسائل التقويه لأداء الطالب المعلهم.

إحداث التكامل والترابط بـين الجوانب النظريـة والتطبيقية لبرنامـج إعداد المعلهم.

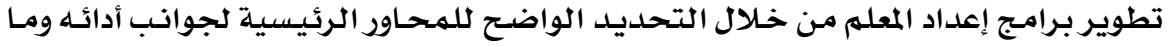
يرتبط بـه من مؤثـرات وسلوكيات تعكس واقع ومستويات هذا الأداء. - توحيد توجهات المؤسسـات عن إعداده. تطوير البرامـج التدريبية لصقل المعلم أثناء الخدمـة لموسة

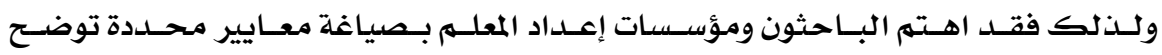
المتطلبـات الفنية لإعداد المعلم، ومنها ما وضعته الهيئة الوطنية للهعايير المهنية للتدريس فِ الولايـات المتحسدة الأمـريكيـة National Board for Professional Standard كما يلخهصها No03 (2003) : Odden 


$$
\begin{aligned}
& \text { ا. ا. الاهتمام بالمعرفة المهنية أو الالتزام المهني }
\end{aligned}
$$

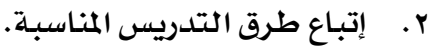

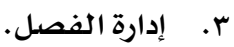

$$
\begin{aligned}
& \text { ع. التعليهم من خلال الدارة الفهل. } \\
& \text { ه. الإحساس بالانتماء. }
\end{aligned}
$$

و يـذكر (2005) Morton أنه طبقاً لـدليل تقويم المعلهم بولايـة ألابامـا فـان إعداد المعلهم

$$
\text { يجب أن يتم وفقاً المعايير التالية : }
$$

$$
\begin{aligned}
& \text { 1. تزويده المعرفة التامسة بمادة التخصص. }
\end{aligned}
$$

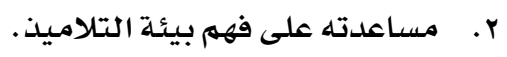

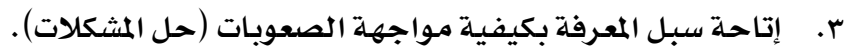

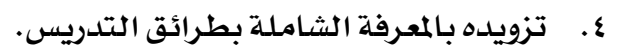

كمها حسددت ولايـة كاليفورنيـا بأمريكـا مـن خـلال اللجنــة الوطنيـة لتقـويهم أداء المعلهـين بكاليفورنيا NCATE (2001) المتطلبات الأساسية التي تحتاج إليها مهنة التدريس بالآتي:

$$
\begin{aligned}
& \text { 1. إثرالك جميع الطلاب هي التعليم. } \\
& \text { r. ت بوفير بيئة فاعلة للتعليه. } \\
& \text { r. ت تنظيم المادة التعليمية. } \\
& \text { ع. تخطيط الخبرات التعليمية. }
\end{aligned}
$$

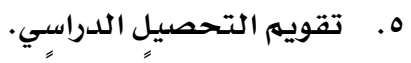

$$
\begin{aligned}
& \text { 7. نهو المعلهم مهنيا وتربويا. }
\end{aligned}
$$

وحددت معايير للعمل بههنة التعليه، ومنها تمتع المعله بما يلي:

$$
\text { ا ب. الثقافة الواسعة يِّ المجالات العقلية والعلوم واللغات. }
$$

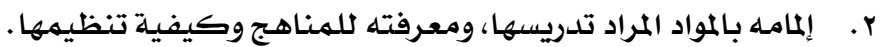

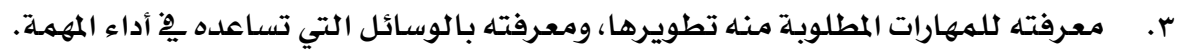

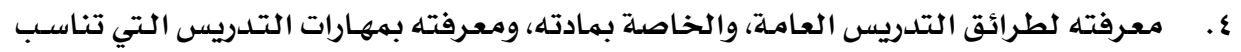

$$
\text { الطلاب باختلاف فئاتهم. }
$$

ه. معرفته بأساليب تقويه الطلاب، والتأكد من تطور نموهم، وقابليتهم للتعلهم واستعدادهم

$$
\text { لتوظيف ما تعلموه لصالحهم. }
$$

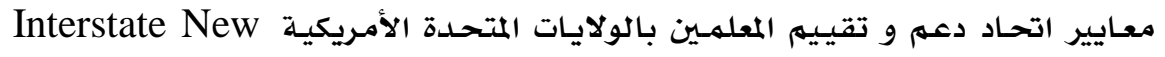
Teacher Assessment and Support Consortium

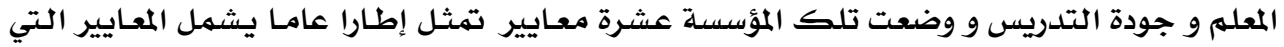

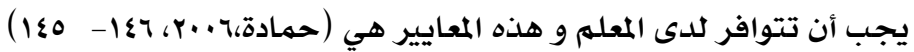




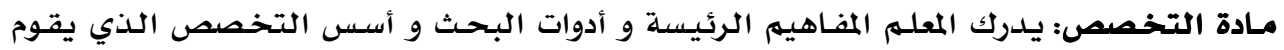

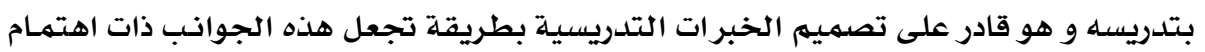
لدى الطلاب.

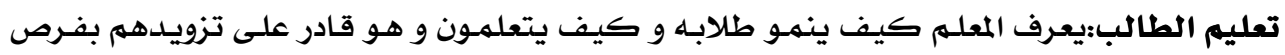

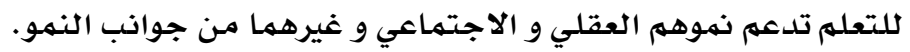

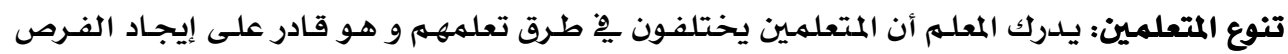

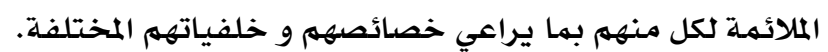

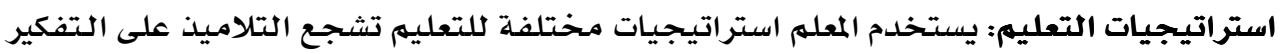
الناقد و حل المشكلات وتنمي مهاراتهم الأدائية.

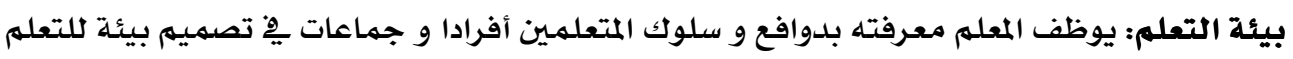

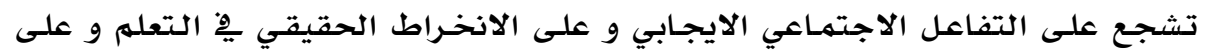

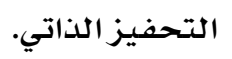

التواصلية: يوظف المعلهم معرفته بطرق التواصل اللفظي و غير اللفظي و بفنيات الاتصال الأخرى التها

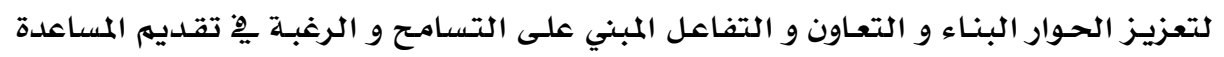
داخل الصف.

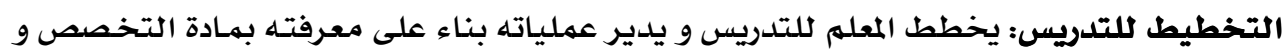

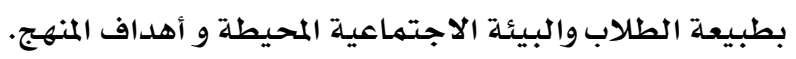

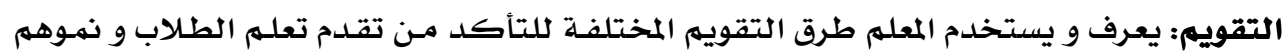
بجوانبه المتعددة.

التأمل و النمو المهني: المعلم ممارس مهني يفكر باستمرار يِّ ممارسته و يقيم النتائج المترتبة عليها

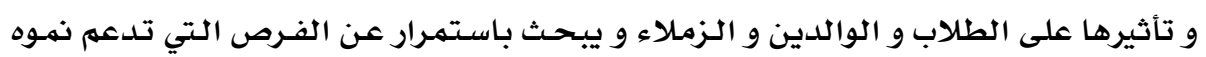

التعـاون و الأخلاقيـات و العلاقاتات: يتواصل المعلهم مـع أوليـاء الأمسور و الأسـر و الزملاء و البيئـة

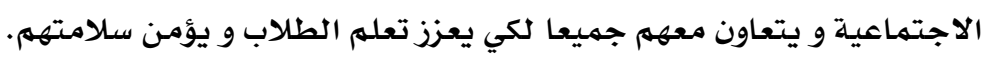

معايير NCATE:

يعتبر المجلس القـومي لاعتهـاد إعــاد المعلمـين NCATE مـن أكثـر المؤسسسـات اهتمـامـا

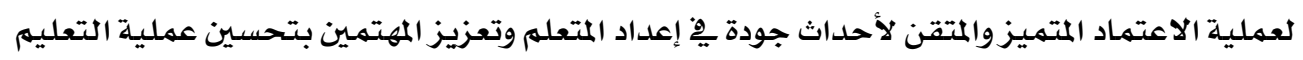
مِِ المدارس أو الكليات وفق ستة معايير أساسية هي: (NCATE, 2000)

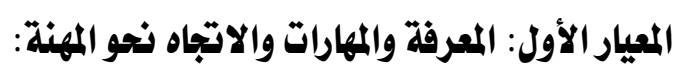

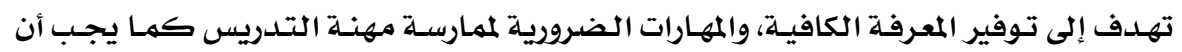

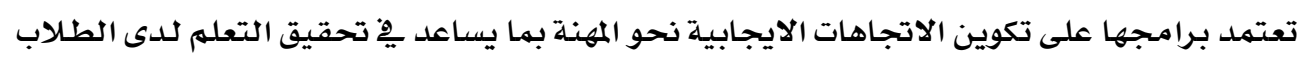


المعلمـين. ويتهم إجراء التقييمات للتأكس مـن استيفاء المرشـحين للمعـايير المعتمـدة مـن قبل المنظمـات

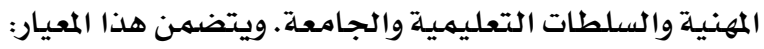

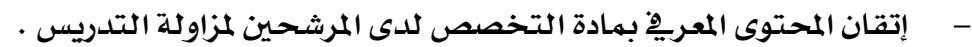

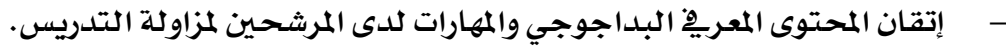

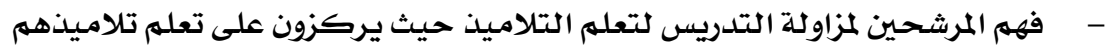

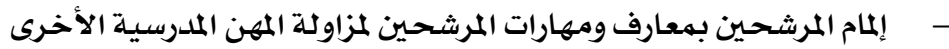

\section{المعيار الثاني : نظام التقويم والامتحانات :}

تتمتع المؤسسـة بنظام تقويهي وامتحانات قويـة تستطيع أن تجمحع البيانات عن الدارسـين بها

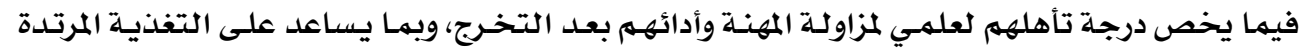

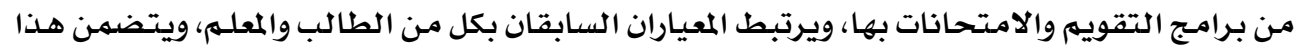

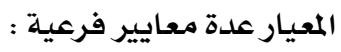

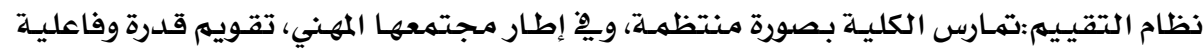
نظامها للتقييه.

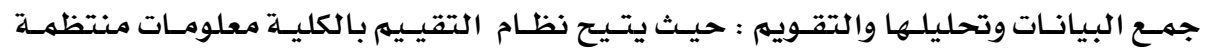

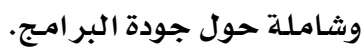

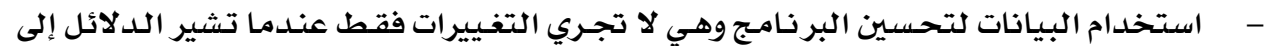

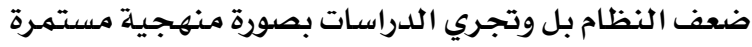

\section{المعيار الثالث: الخبرات الميلدانية والممارسات العملية:}

تقدم المؤسسـة خبر ات ميدانية تقوم بتصميمها وتنفيذها بالاشتراك مـع المدارس بهـا يفيد بِ

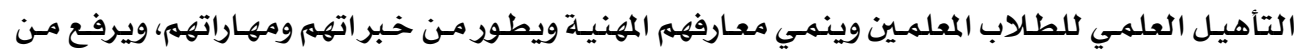

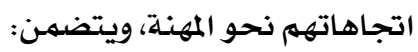

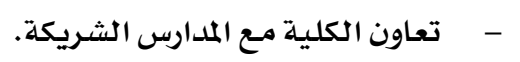

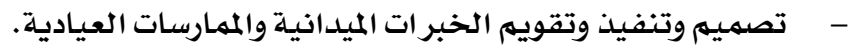

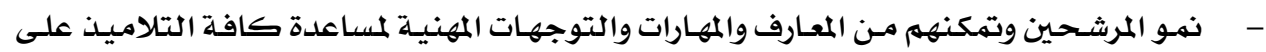

التعلهم

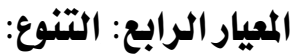

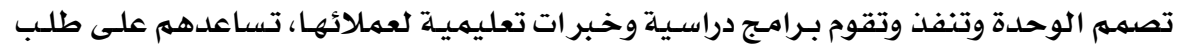

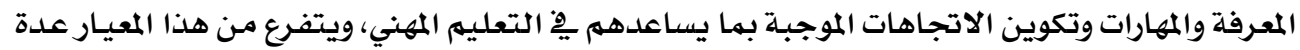
معايير هي : ا. تصميهم وتنفيذ وتقييم المنهج والخبر ات. 


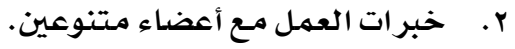

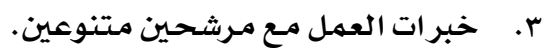

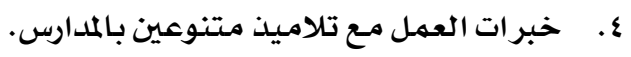

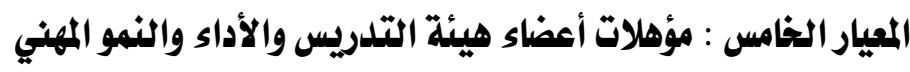

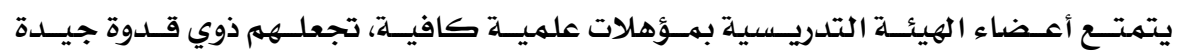

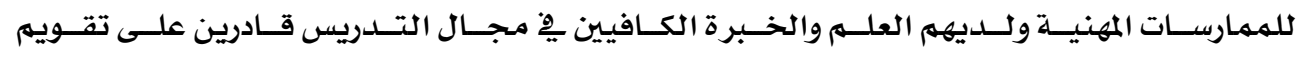

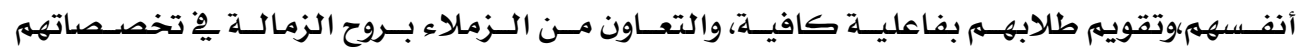

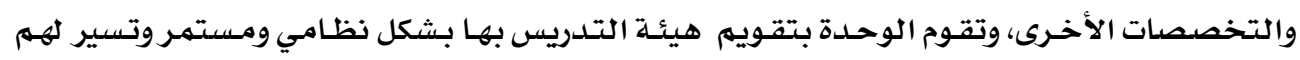
فرص النهو المهني، ويتفرع منـه عدة معايير هي :

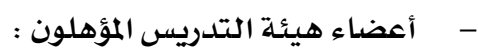

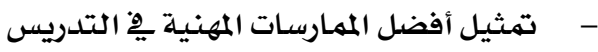

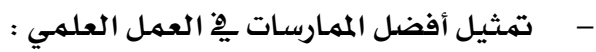

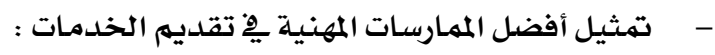

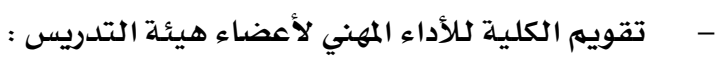

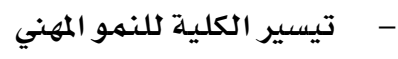

\section{المعيار السادس : الإدارة والموارد}

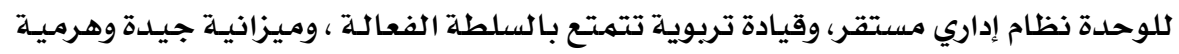

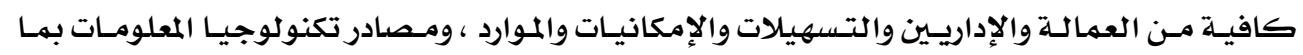

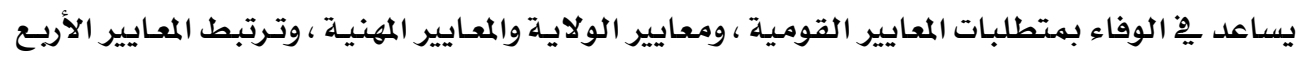
السابقة بالوحدة موضوع الاعتماد والفحص، ويتفرع منسه المعايير التالية:

$$
\text { - }
$$$$
\text { - - 2 - مالتجهيزات والموارد الكلية. }
$$

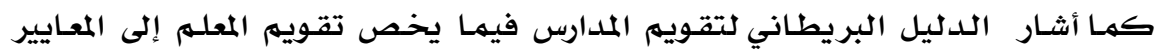

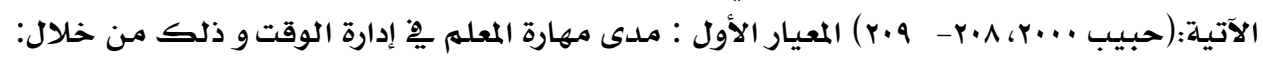

ا. تحضير الأجهزة و المواد و الوسائل المعينة قبل بداية الحصلة.

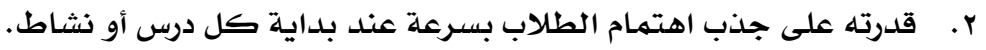

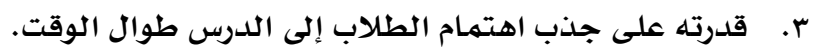




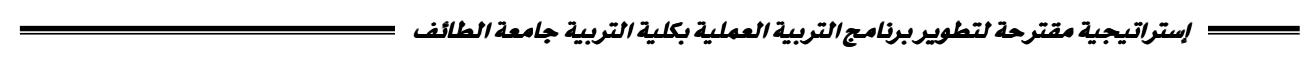 \\ المعيار الثاني : ملى مهارته في إدارة سلوك الطلاب و ذلك من خلال: \\ ا. قدرته على مراقبـة سلوك جميع الطلاب أثناء القيام بالأنشطة المصاحبة للدرس.

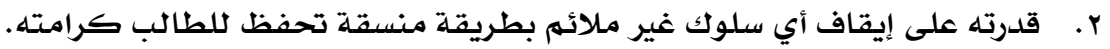 \\ المعيار: الثالث مهارته في التخطيط للدرس و ذلك من خلال: \\ 1. قدرته على تحديد الأهداف المناسبة و صياغتها بطريقة سليمهة.

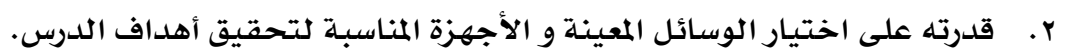

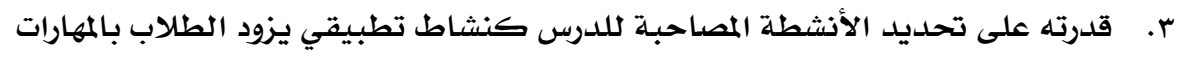

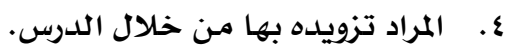

المعيار الرابع : مهارته في تنفيذ الدرس بطريقة تحقق أقصى استفادة للطلاب من خلال:

$$
\begin{aligned}
& \text { 1. قدرته على ريط الدرس بالبيئة و بالدروس السابقة و المواقف الحياتية. }
\end{aligned}
$$

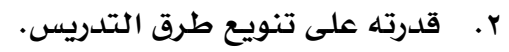

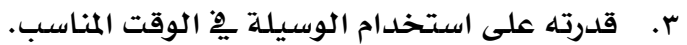

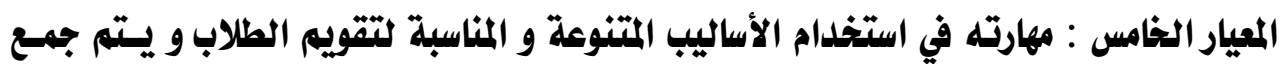

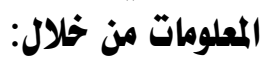

$$
\begin{aligned}
& \text { 1. مشاهدة الدروس بملاحظة أداء المعلم أثناء الحصة. } \\
& \text { r. مناقشة الطلاب. } \\
& \text { r. r. . فحص دفتر التحضير. } \\
& \text { ع. ـ مناقشة مـع المدرس الأول. }
\end{aligned}
$$

0. تزويد الطلاب بتغذية راجعة عن صحة أدائهم داخل الفصل و خارجه وتشجيعه لنموهم.

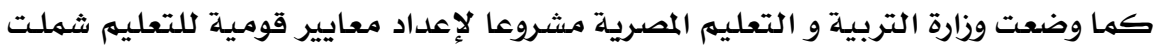

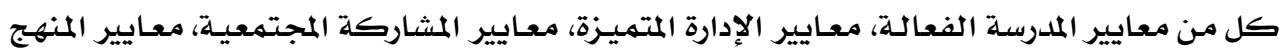

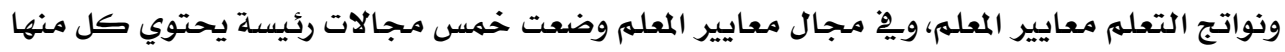

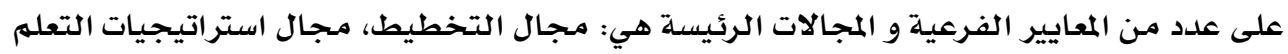

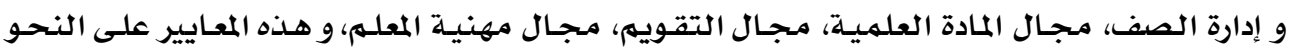

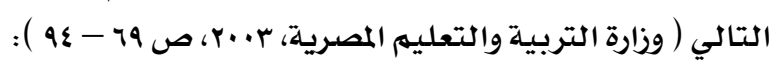

\section{المعيار الأول : تخطيط و تصميه المواقف التعليمية، وتشمل مؤشراته:}

ينمي قدرة التلميذ على تطبيق المعرفة و المهارات و عمليات التفكير.

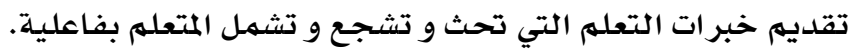

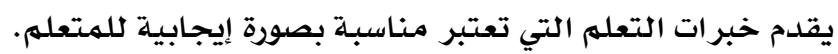

\section{r. r}


يهيئ بيئة طبيعية داخل الفصل الدراسي لتدعم أشكال التدريس و التعلهم المقدمـة.

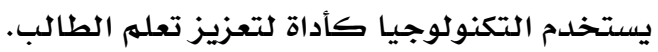

المعيار الثاني : إيجاد المناخ التعليمي و الحفاظ عليه وتشمل مؤشراته:

$$
\text { يتصل و يحفز التالاميذ بسلوك ايجابي و مدعم. }
$$

يوضـح الإحساس بالفروق الفرديـة و الأكاديميـة و الاجتماعيـة و الثقافيـة و الاستـابـابة لكل التلاميذ بسلوك مقبول.

يوضح المرونة و تعديل العمليات الإجراءات داخل حجرة الدراسلة وكما يتطلبها الموقف.

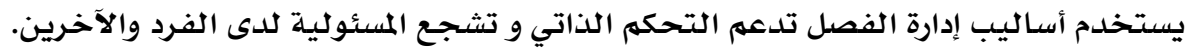

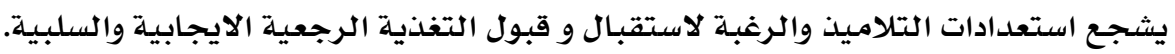
المعيار الثالث : تخطيط و إدارة الموقف التعليمي وتشمل مؤشراته:

$$
\text { يوضح معايير محددة و توقعات مهمة للتعليه. }
$$

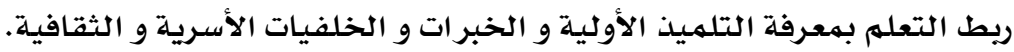

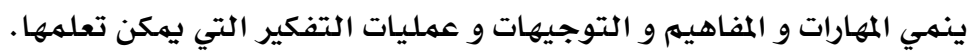

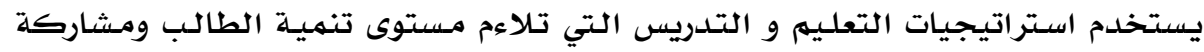
الطلاب بفاعلية وخبر ات تعلهم فردية و معاونة.

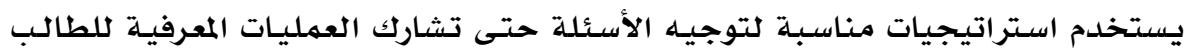
وتشجع التفكير المنظم. يرشـد الطلاب للتعبير و فحص و شـرح الاستجابـات البديلـة و نتائجها المرتبطة بالقضايا

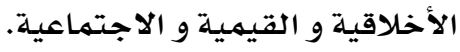

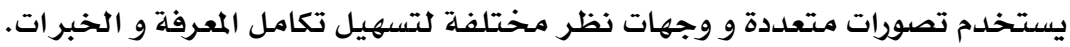

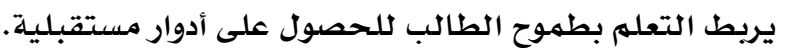
المعيار الرابع : تقييم و متابعة تتائج التعلم وتشمل مؤشراته: يستخدم تقنيات متعددة و مصادر للبيانات.

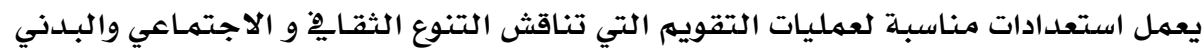

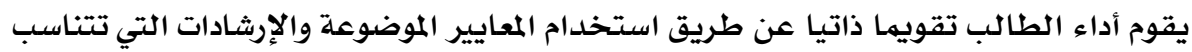
مـع برنامج التقييهم. - - يجمع ويحلل بيانات التقييم و حفظ السجلات الحديثة لتقدم الطالب. 


\section{الميار الخامس : تأمل و تقيييم الموقف التعليمي وتشمل مؤشراته:}

يقوم و يحلل و يتصل بدقـة لتحقيق فاعليـة التعلم و أن يقوم بـالتغييرات المناسبة مـن أجلل

تحسين تعلهم التلاميذ.

يحلل و يقوم آثار خبر ات التعلهم على الأفراد و على الفصل تهل ككل.

المعيار السادس : التعاوز مع الزملاء و الواللين و الآخرين وتشمل مؤشراته:

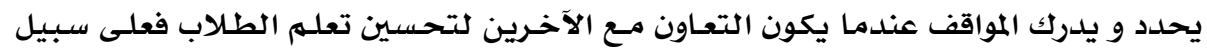

المثال اتخاذ القرارات ِِّْ المدارس.

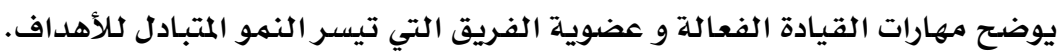

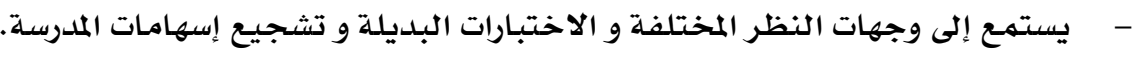

المعيار السابع : المشاركة في التنمية المهنية وتشمل مؤشراته:

- - يوضح نقاط القوة و الأولويات للتنمية.

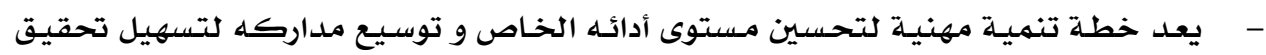

الطالب لهدف التعله.

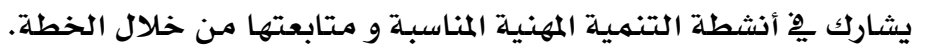

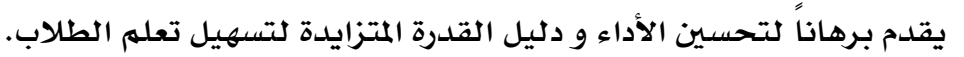

المعيار الثامن : الإمام بالمحتوى وتشمل مؤشراته :

يوضتح المهارات بدقة و المفاهيم المحورية المرتبطة بالمجالات الأكاديمية المؤهلة.

يطبق المنهج الاستقصائي بفاعلية.

- - يريط المعرفة بالمجالات الأكاديمية المؤهلة لمواقف الحية الحياة الحقيقية.

المعيار التاسع : تطبيق التكنولوجيا وتشمل مؤشراته :

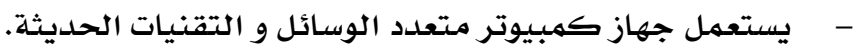

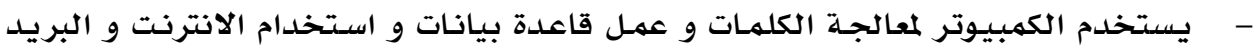

الالكتروني.

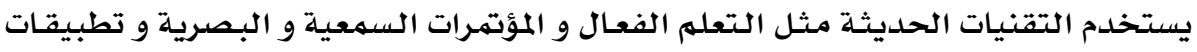

التعلهم عن بعد لتحسين الإنتاجية.

- - يستخدم وسائل معينة و مساعدة للطلاب ذوي الاحتياجات الخداصدة.

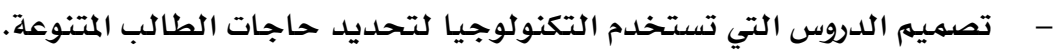




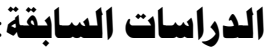

\section{أولاً:الدراسات التي تناولت التعليه التمركز حسـول الطالب}

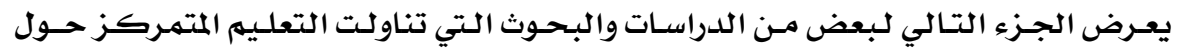

الطالب من زوايا مختلفة:

انتهت دراسـة (2002) Sănchez-Contreras, et al إلى صياغة إستراتيجية لتطوير

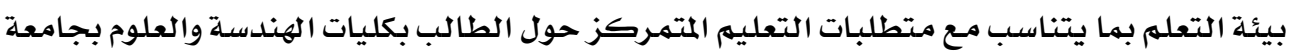

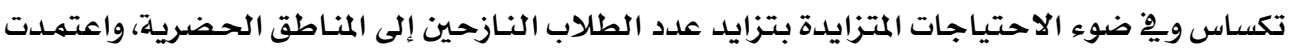

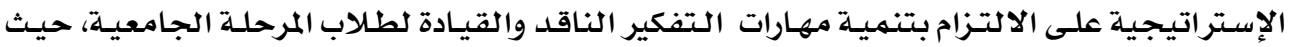

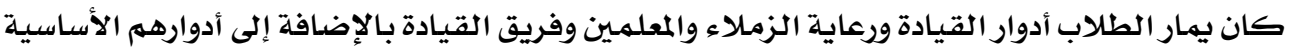

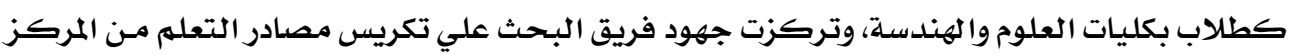

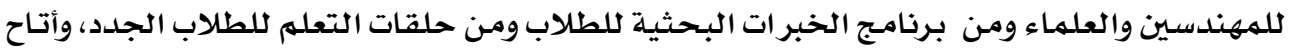

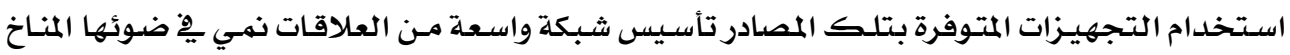

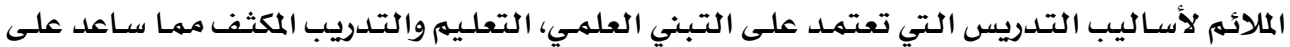

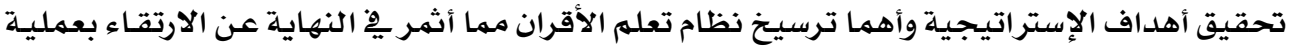

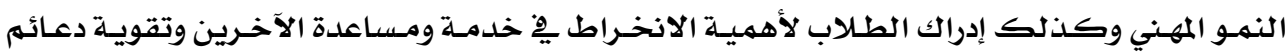
مجتمـع التعلهم.

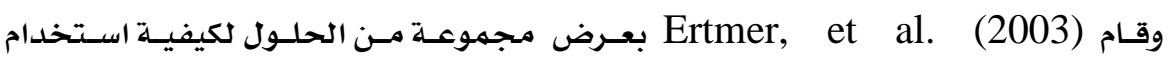

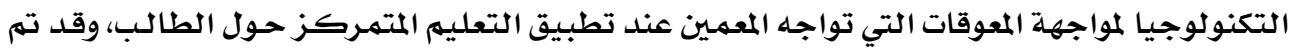

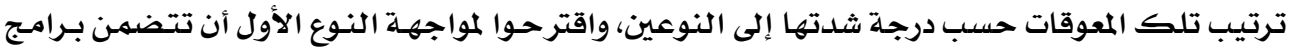

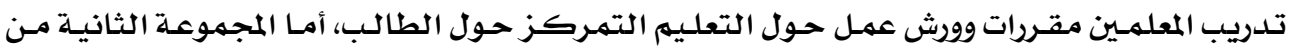

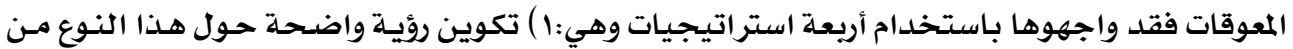

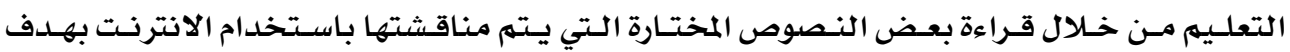

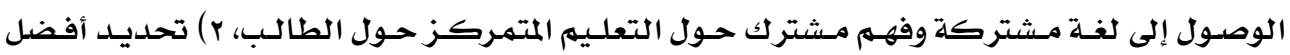

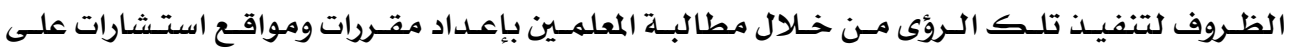

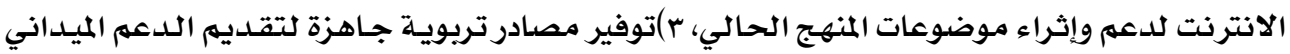

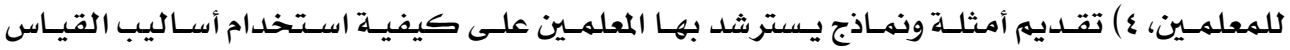

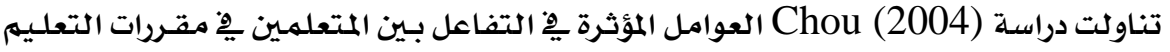

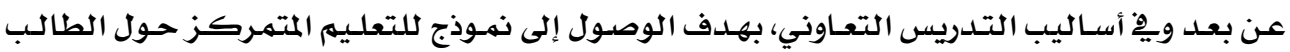

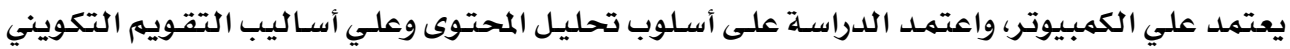

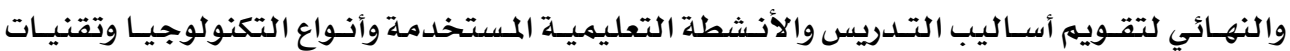




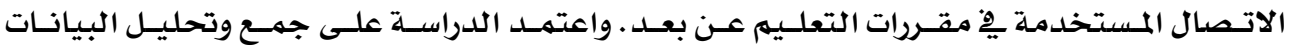

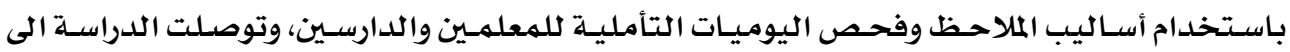

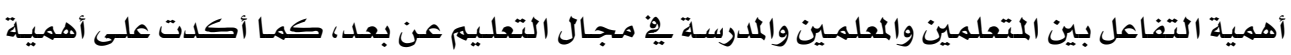

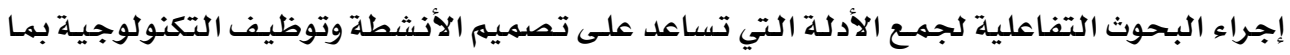

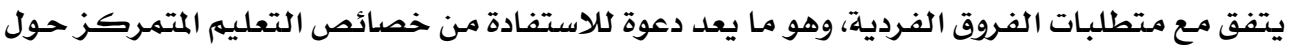

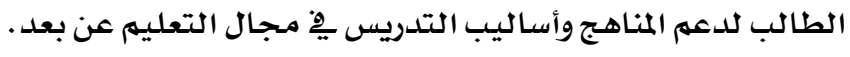

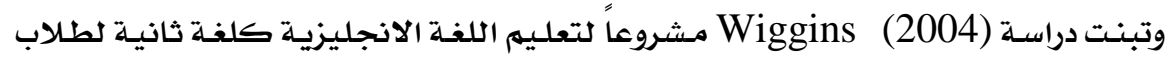

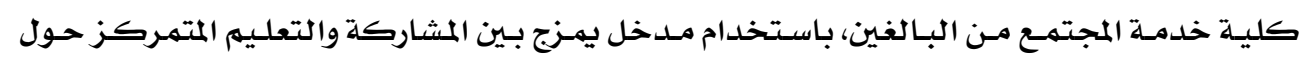

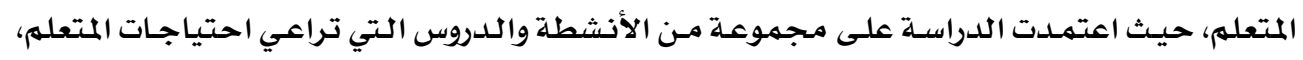

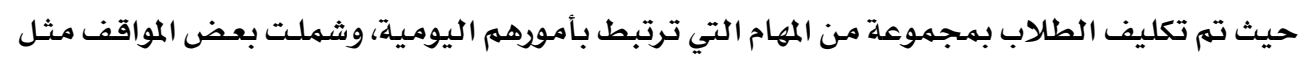

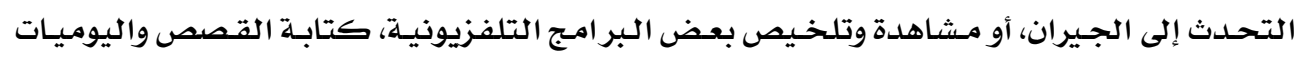

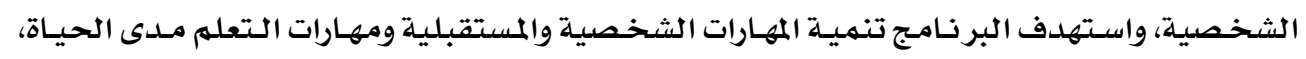

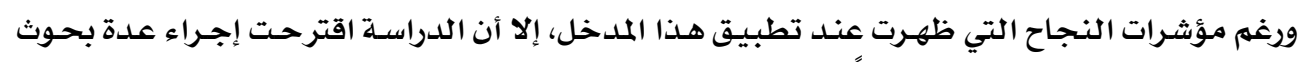

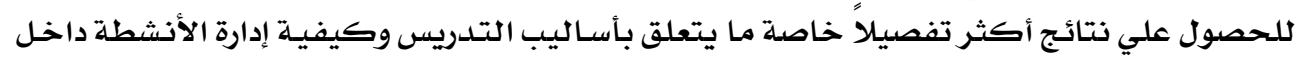
الفصل.

تقدم دراسـة كل من Mccombs \& Vakili (2005 إطارا للتعلهم الاليكتروني يِّ ضوء

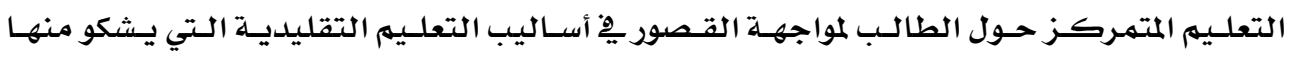

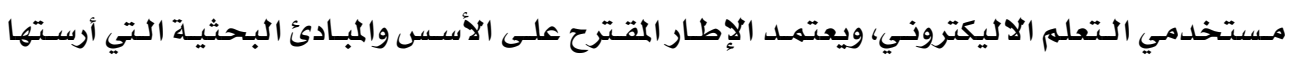

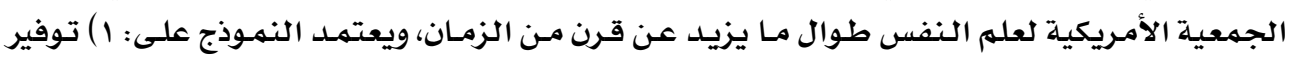

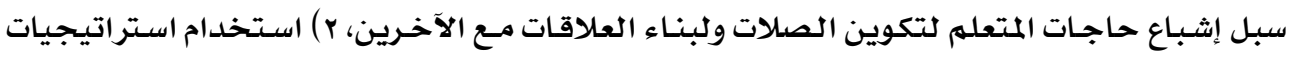

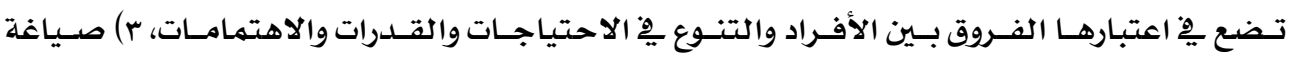

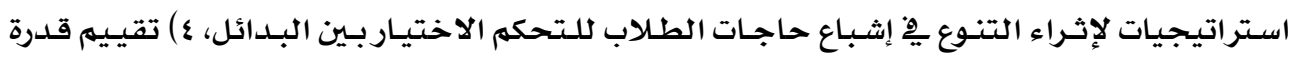

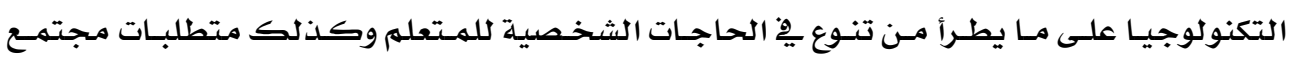
التعلهم.

واهتمت دراسة (2006) Ware بتقييم دور التعله الاليكتروني المتمبركز حول المتعلم عند

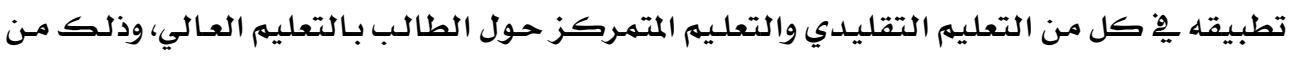

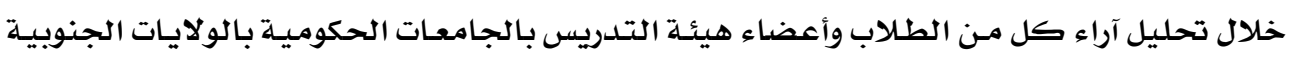

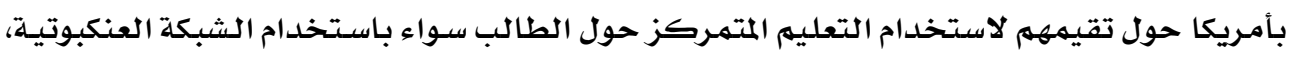

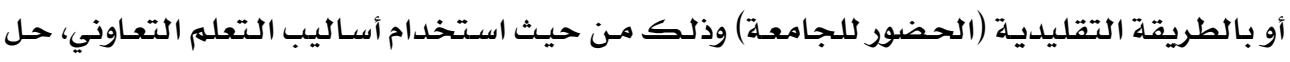

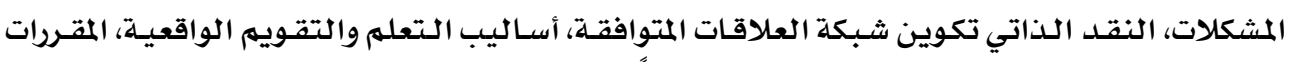

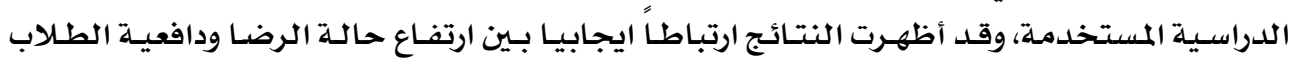

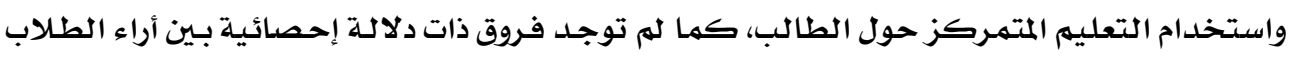


فيما يخص استخدام هذا النوع من التعلهم سواءً بالطرق التقليديـة أو مـن خـلال الطـرق الاليكترونيـة،

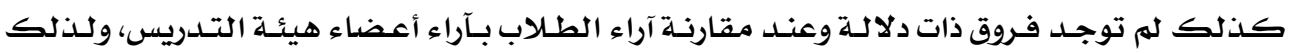

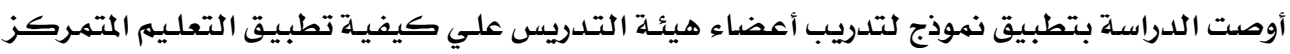
حول الطالب، ِِّ ضوء ما توصلت إليده من نتائج ايجابية.

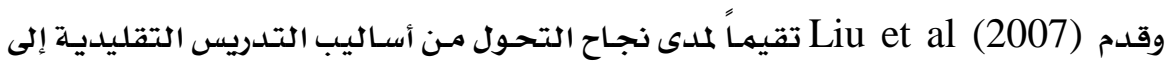

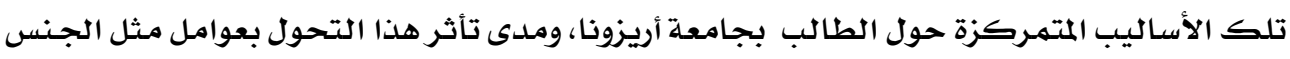

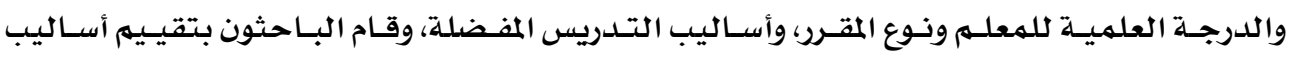

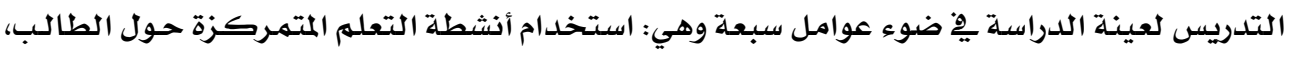

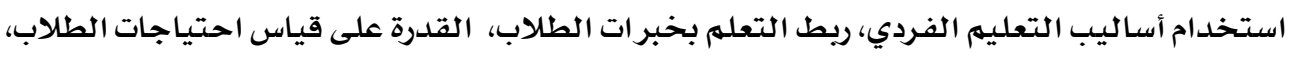

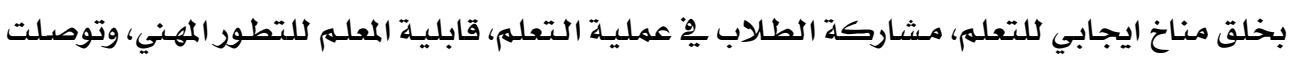

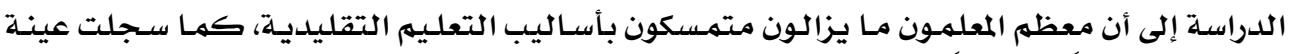

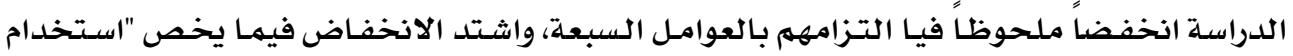

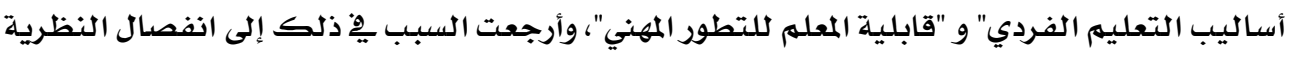

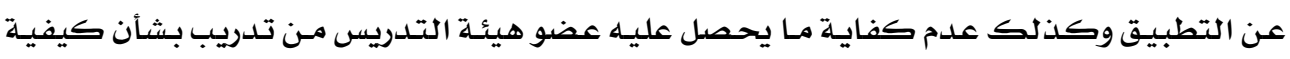
تطبيق أساليب التعليه المتمركز حولكول علئ الطالب.

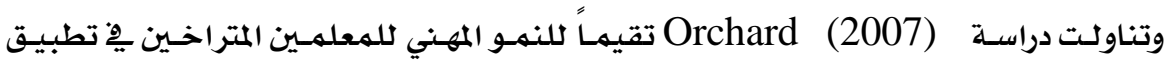

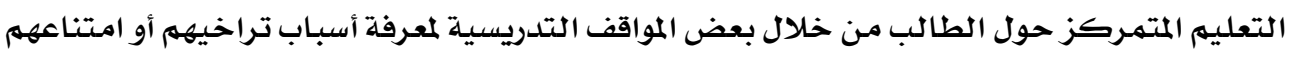

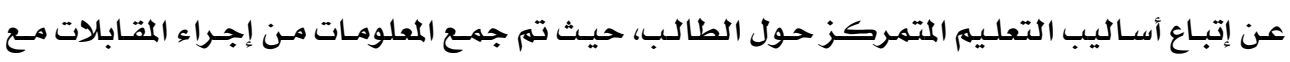

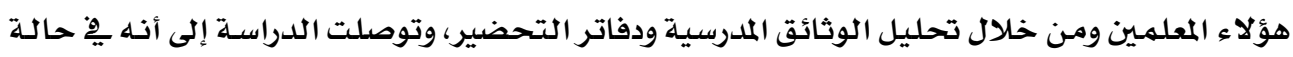

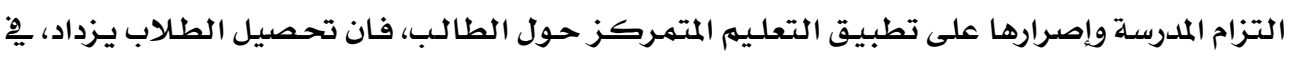

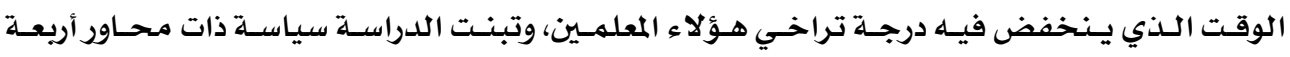

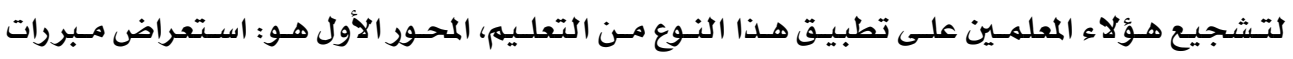

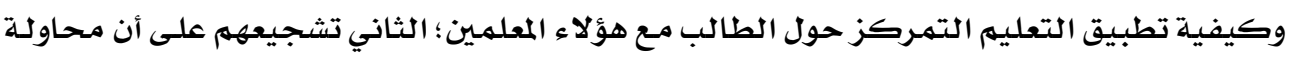

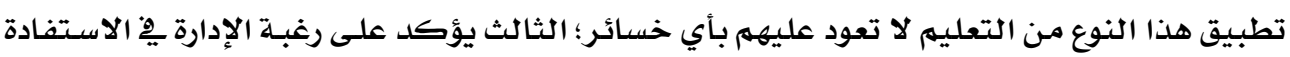

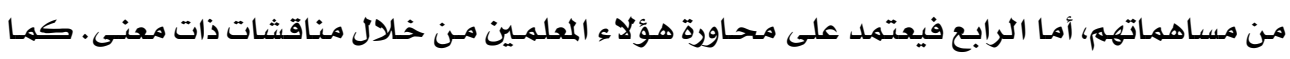

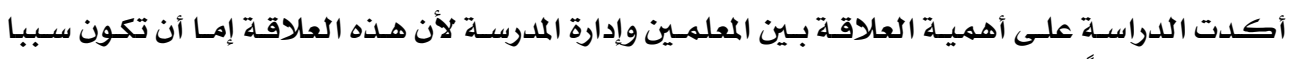

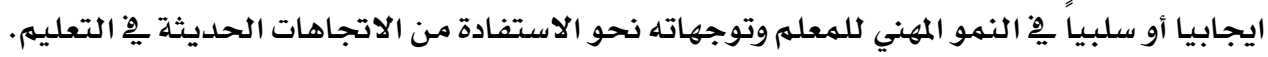

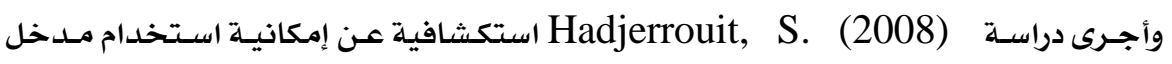

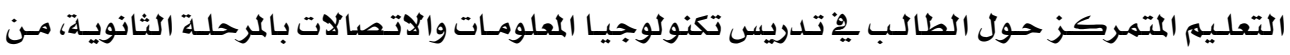

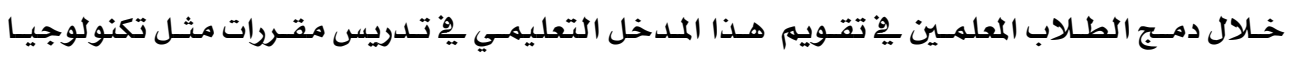

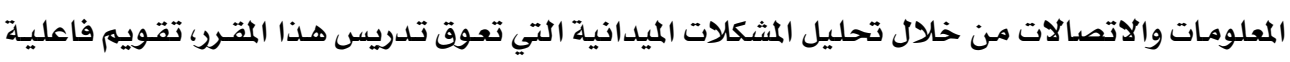

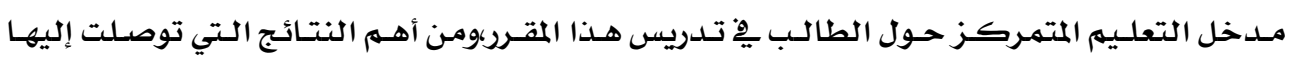




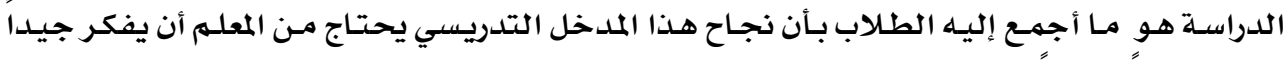

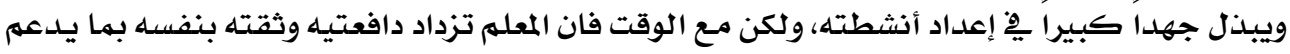

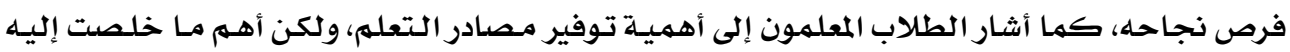

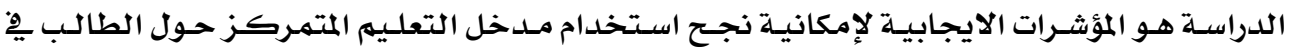

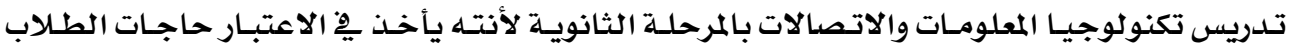

وخصائصهم.

وقام (2008) Wohlfarth, et al بدراسـة مفاهيم الطلاب حول التدريس المتمركز حـول

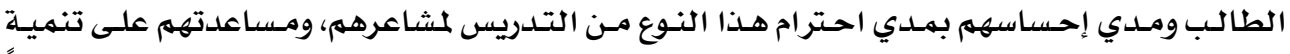

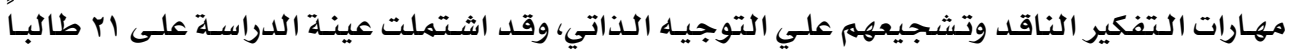

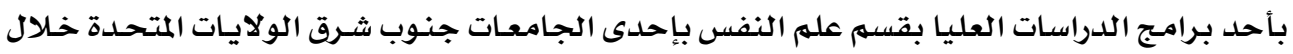

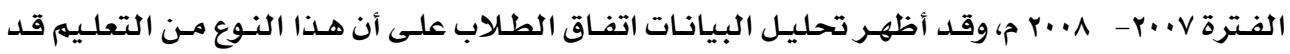

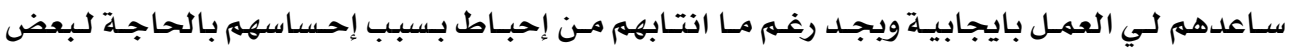

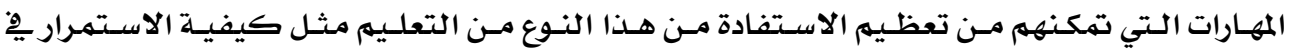

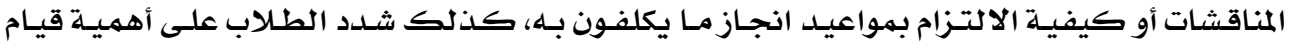

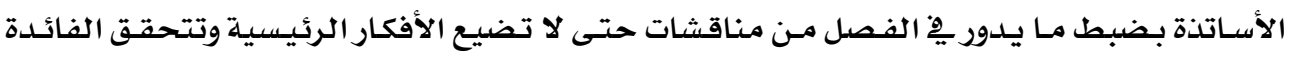

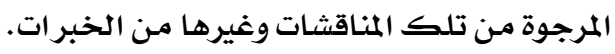

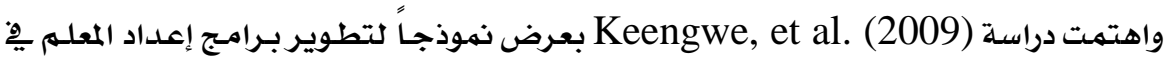

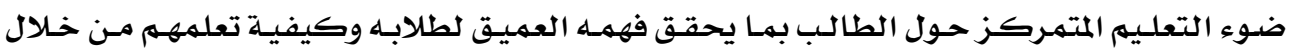

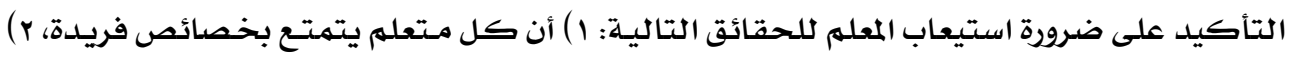

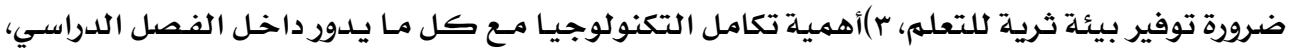

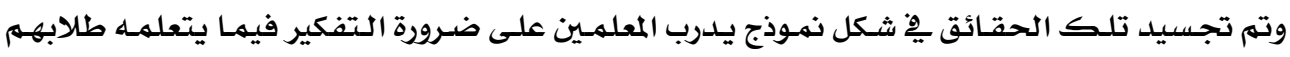

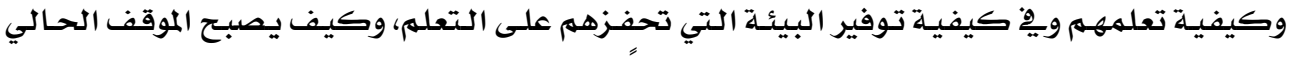

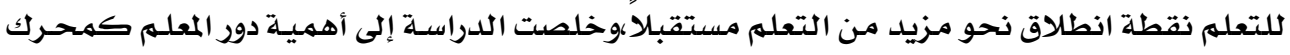

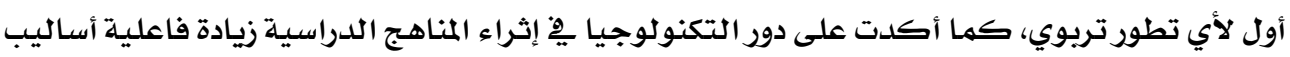
التدريس.

كما قدمت دراسـة Flores (2010) نموذجا لتعلم الرياضيات وممارستها ِِّ ضوء التدريس

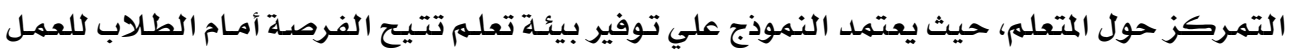

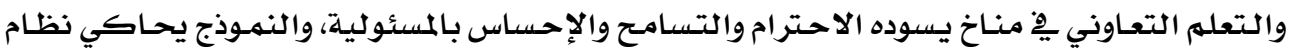

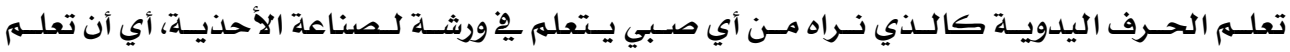

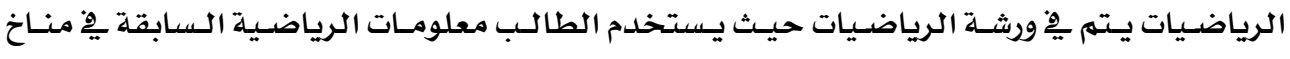

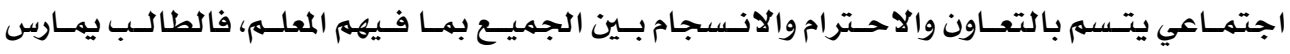

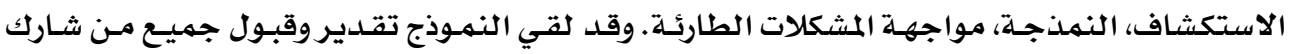


فيـه، حيـث أثبـت البيانـات التتي تم جمعها مـن خـلال يوميـات الطلاب وآرائهـم النهـوذج المقترح زاد مـن مستوى دافعية الطلاب ومن تقديرهم لذاتهم.

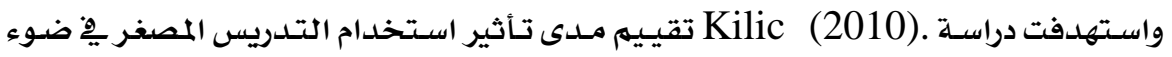

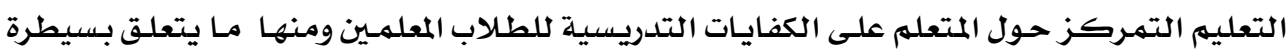

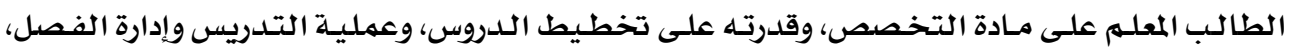

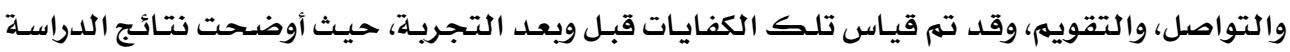

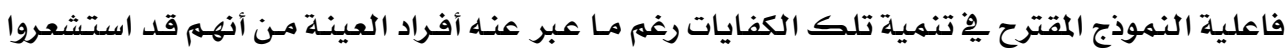

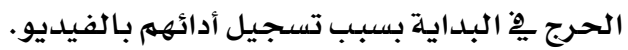

\section{ثانياً: دراسات اهتمت بتقويم برنامج التربية العملية:}

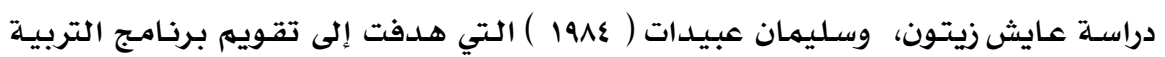

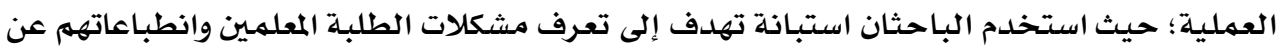

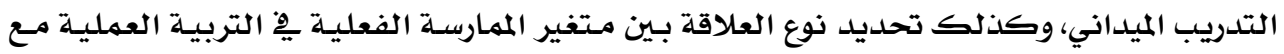

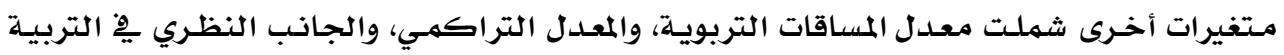

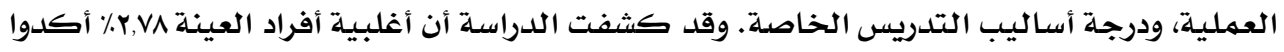

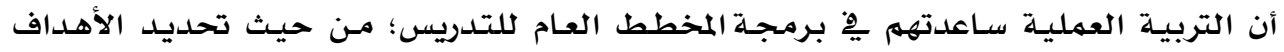

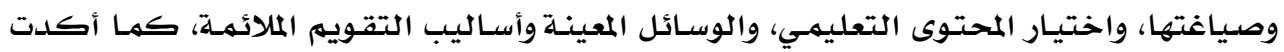

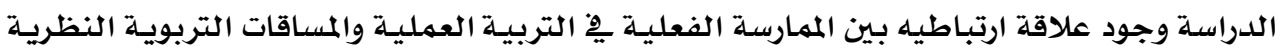

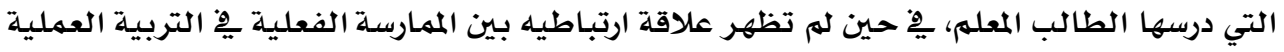
والمعدل التراكهي يِّ الجامعـة.

وأما دراسـة كلٍ من سعد جاسه، محمد عودة ( •199 ) فكانت دراسـة تقويميـة لأثر التربيـة العملية يِّ إكساب الطالب المعلم الكفايات التعليمية. وشمملت العينة (

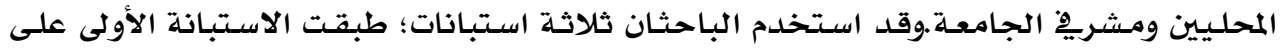

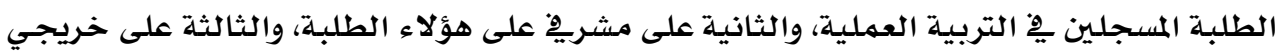

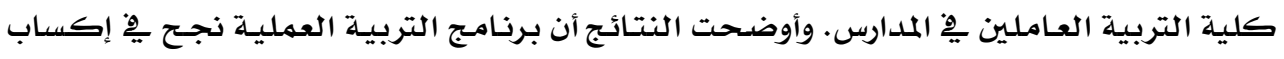

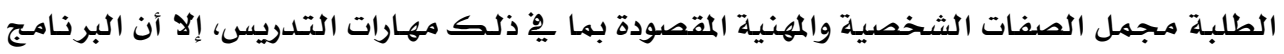

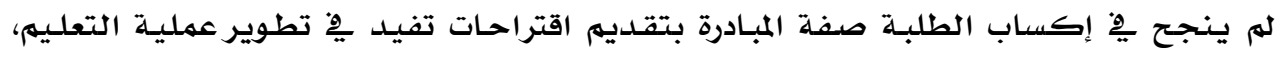

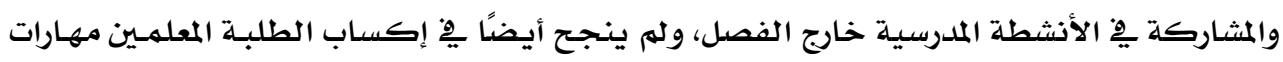

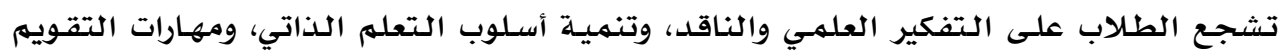

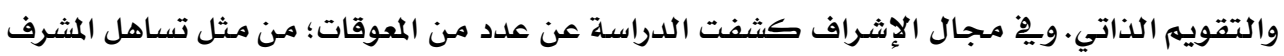

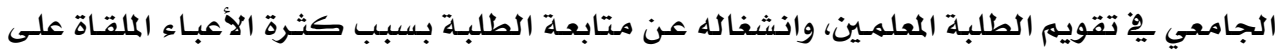

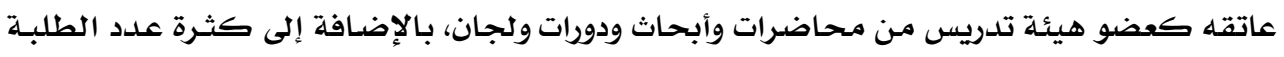

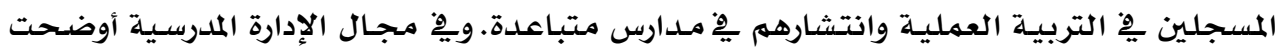


النتائج أن تشدد إدارة المدرسة المتعاونة ِيْ التعامل مـع الطلبة المعلمـين، وانشغالها عن متابعـة الطلبـة

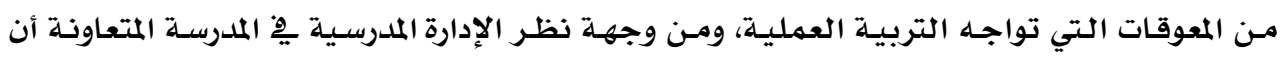

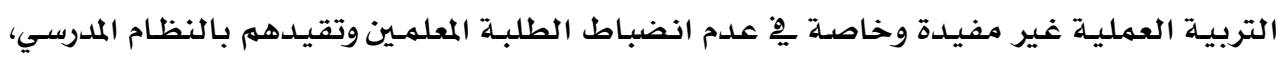

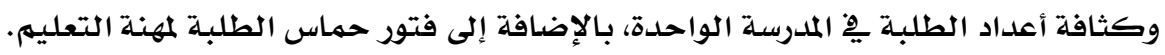

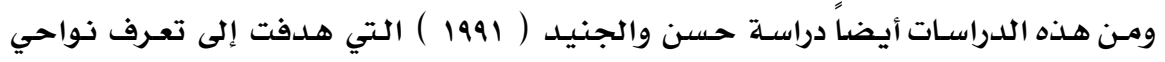

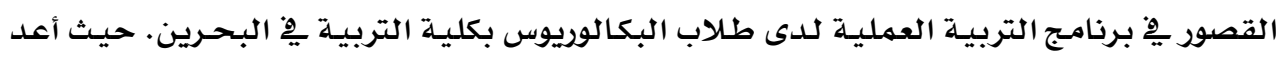

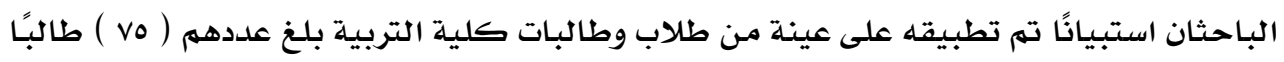

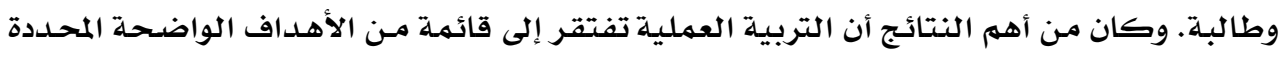

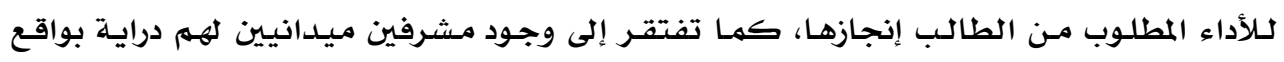

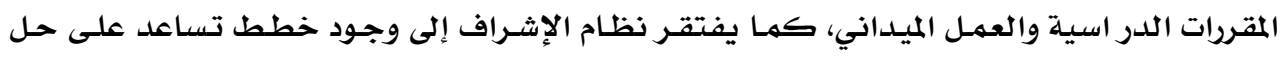
الصعوبات التي يواجهها الطالب يِّ التربية العملية.

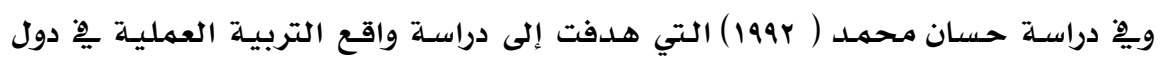

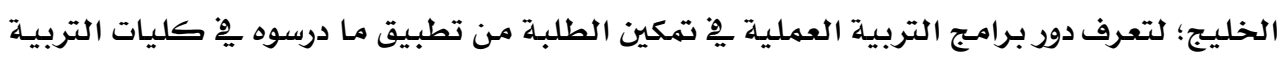

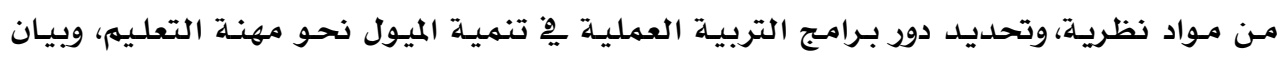

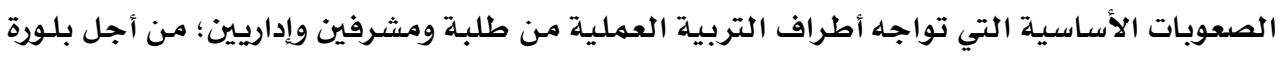

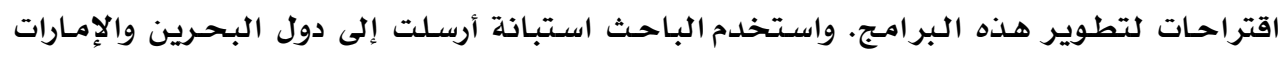

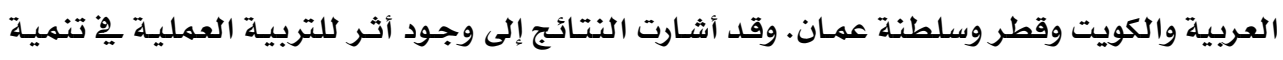

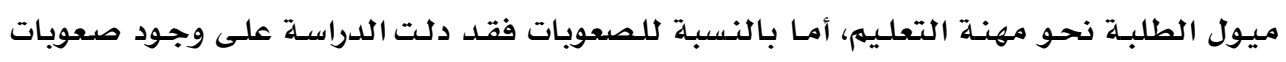

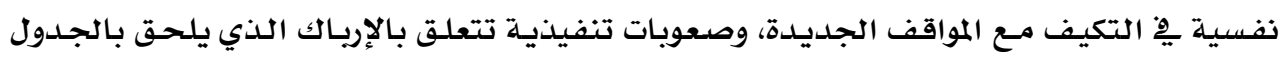

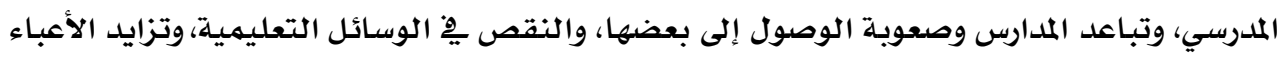

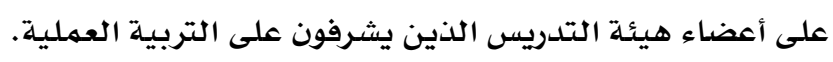

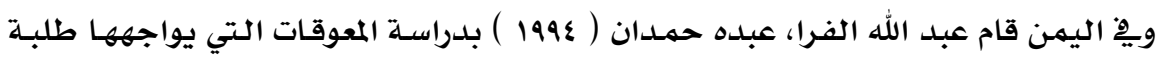

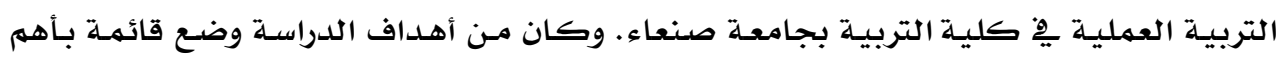

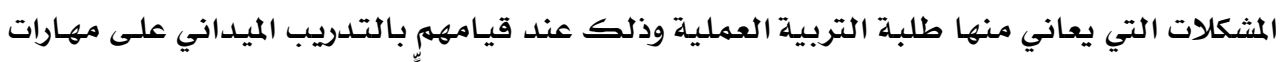

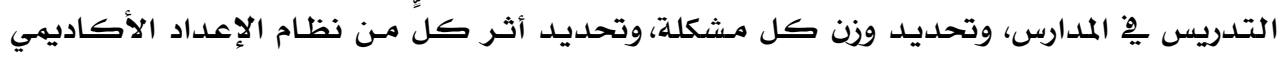

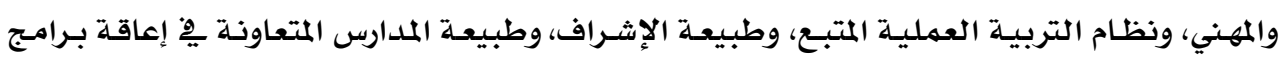

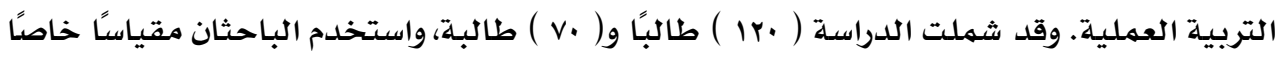

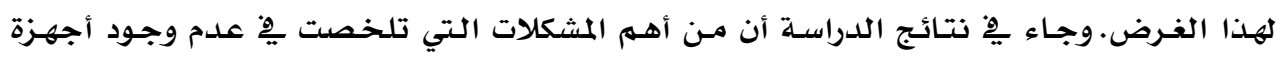

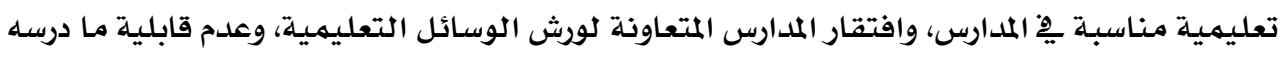

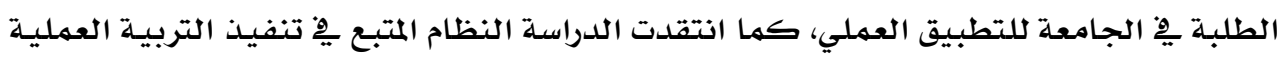

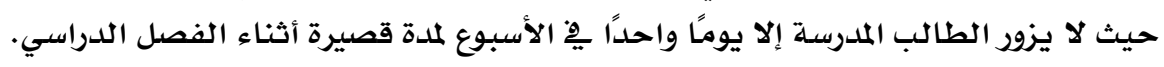


أجـرى المصلحي (1990) دراسـة هـفت إلى تقـويم تدريب الطلبـة المعلمـين تخصص تربيـة

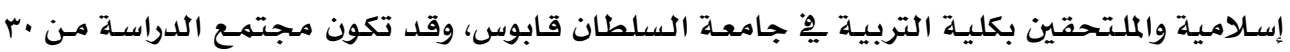

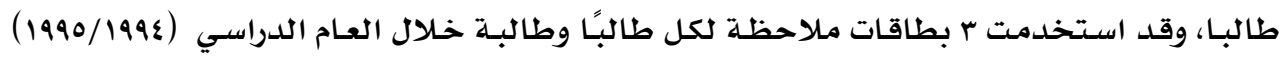

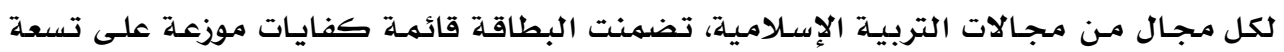

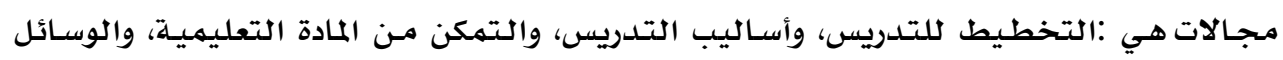

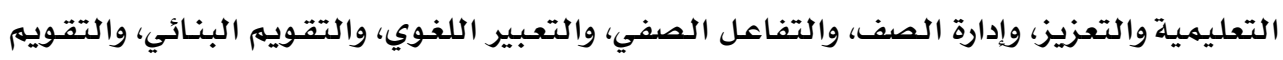

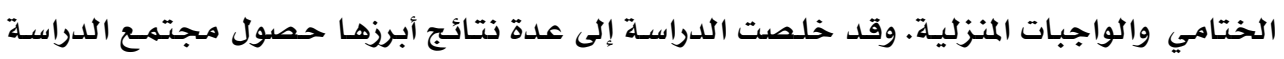

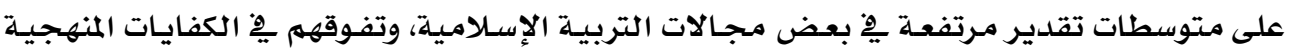

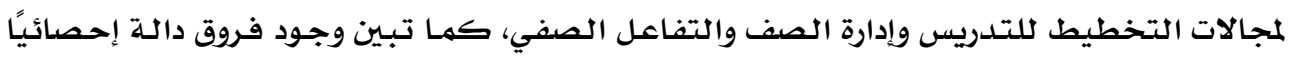

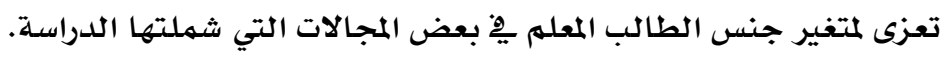

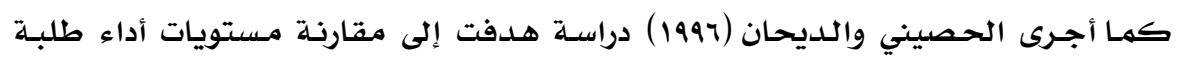

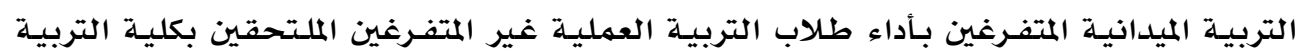

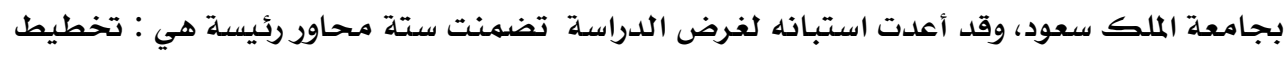

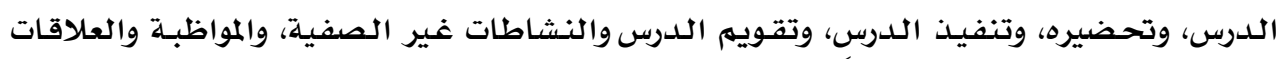

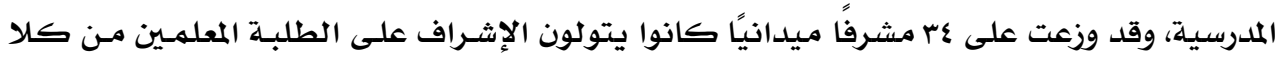

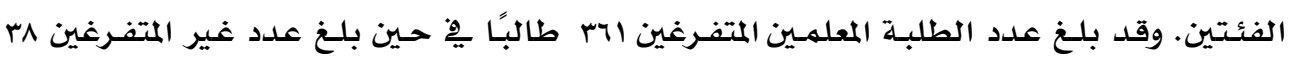

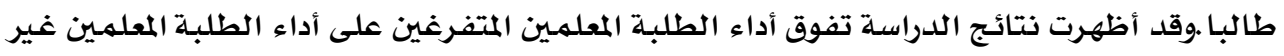

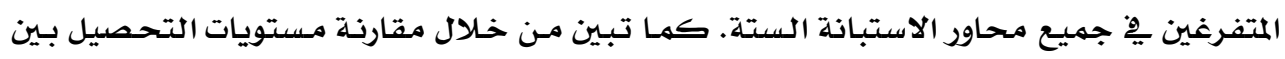
كلا المجموعتين تفوق المستوى ألتحصيلي للمتفرغين.

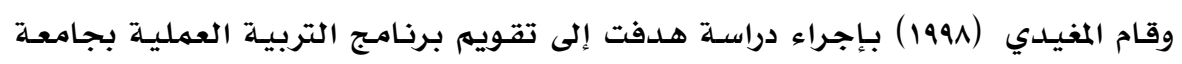

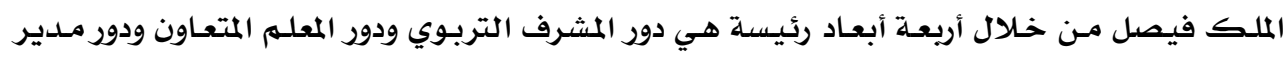

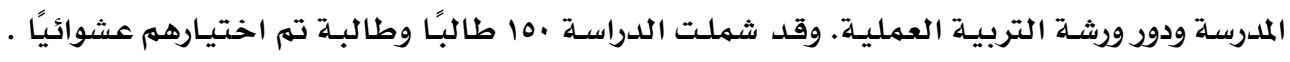

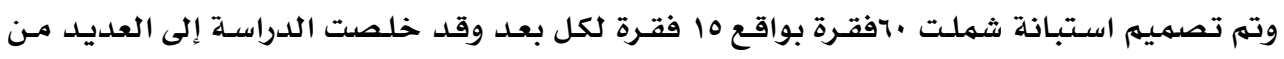

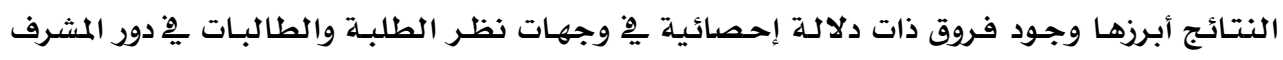

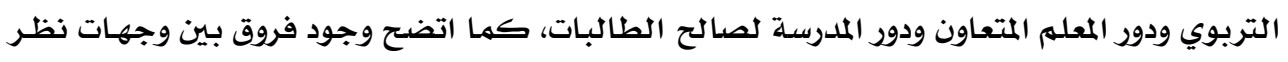

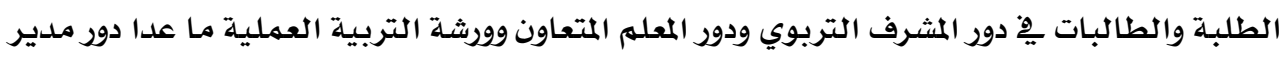

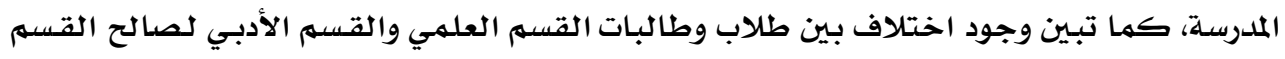

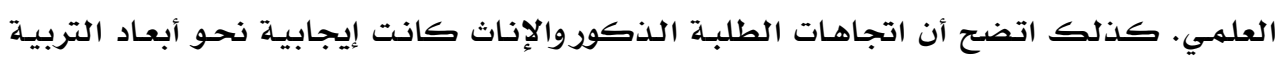
العملية.

و هدفت دراسـة تركي ذياب ( 1999) إلى استقصاء ميـول الطلبـة المعلمـين نحو برنـامـج

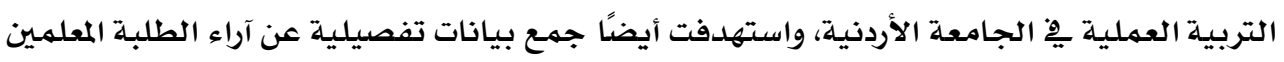

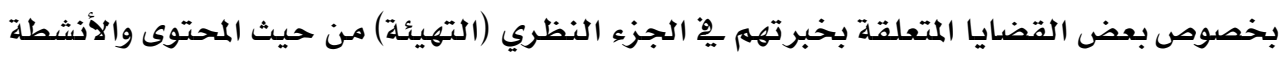


والأسـاليب والتقويم، وخبرتهم خـلال الجزء العملي( الميداني) مـن حيث بعض الجوانب الإداريـة

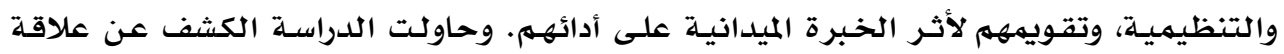

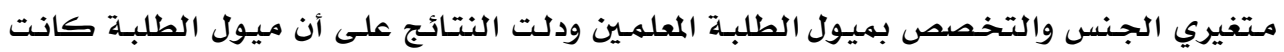

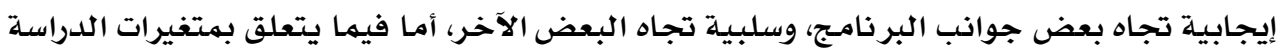

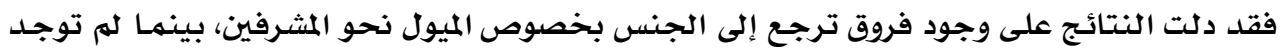

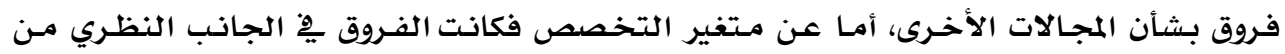

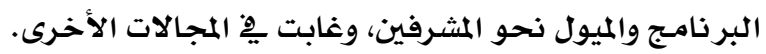

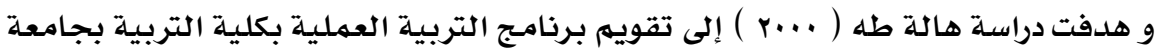

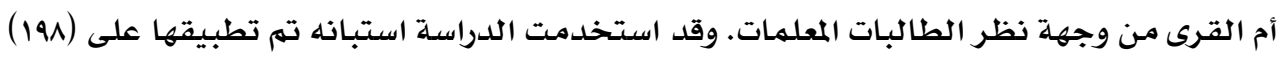

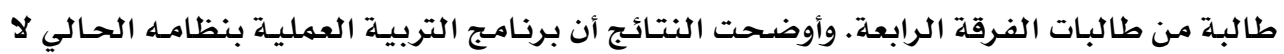

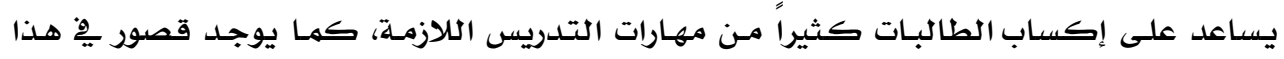

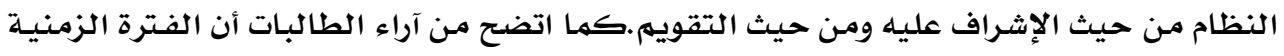

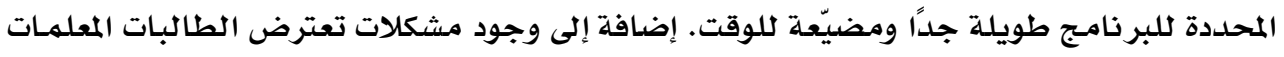

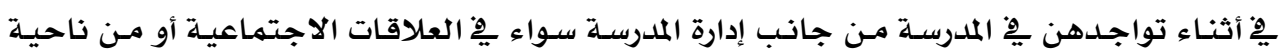
موضوعية تقويم الطالبات المعلمات.

كذلك أجـرى (Kyriacou \& Stephens 1999) دراسـة اسـتهدفت تعـرف اهتمامـات

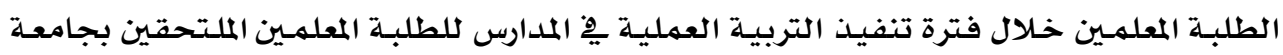

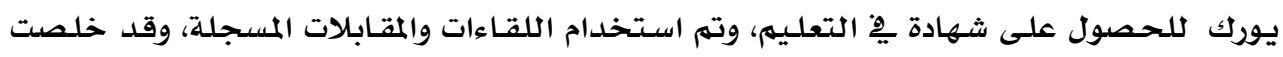

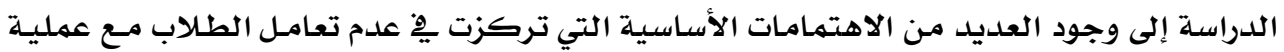

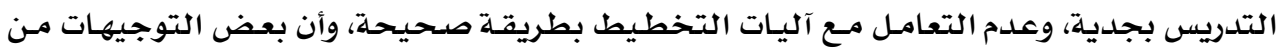

$$
\text { مشرفيهم كانت قاسية وصارمـة وغير مبررة. }
$$

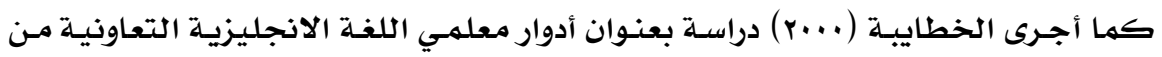

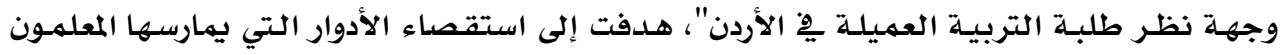

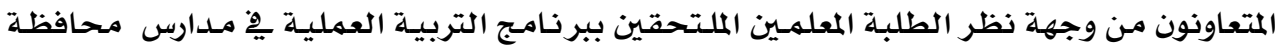

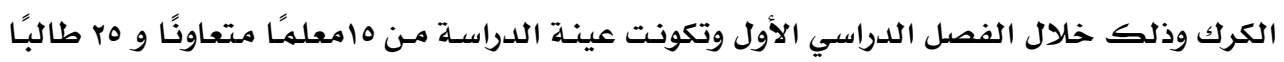

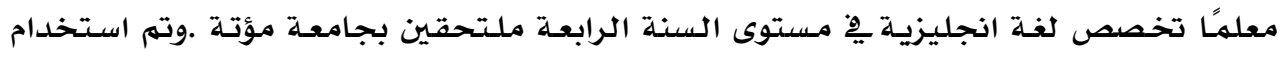

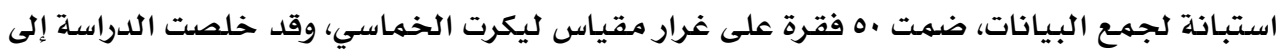

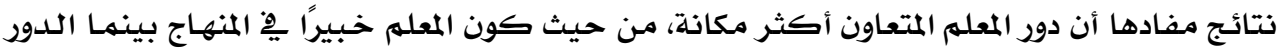

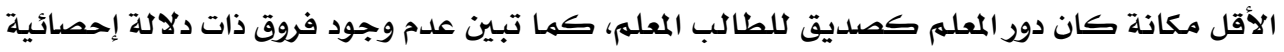

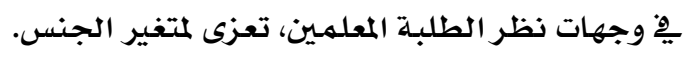

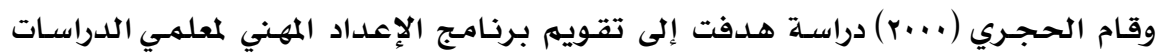

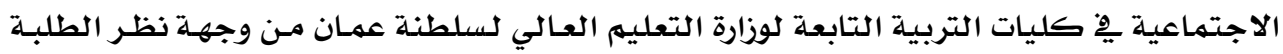




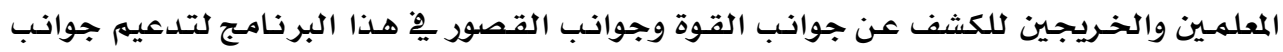

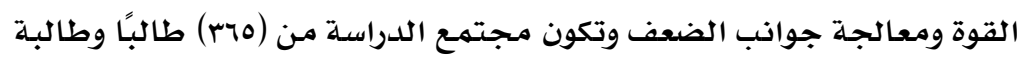

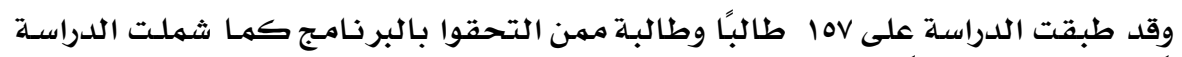

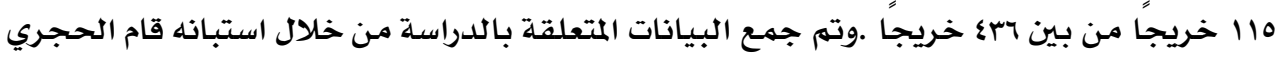

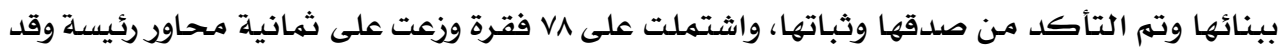

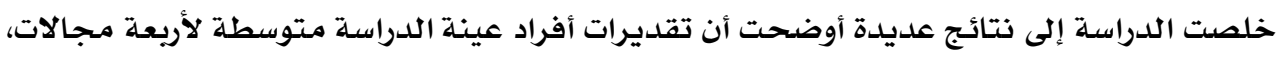

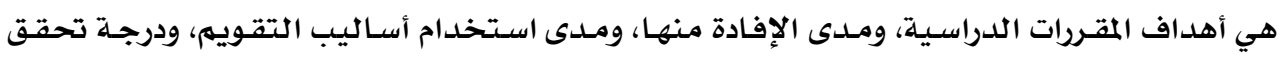

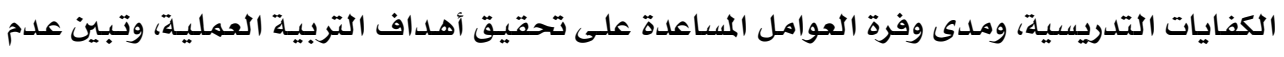

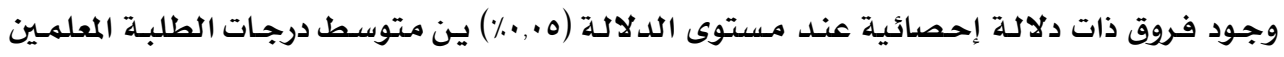

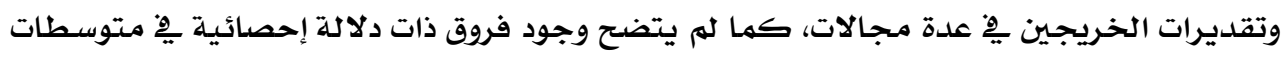

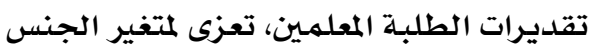

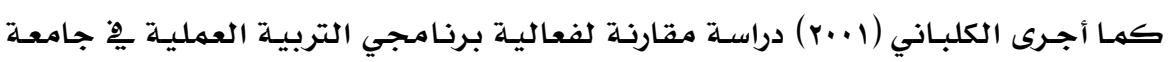

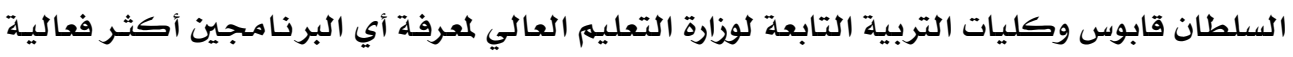

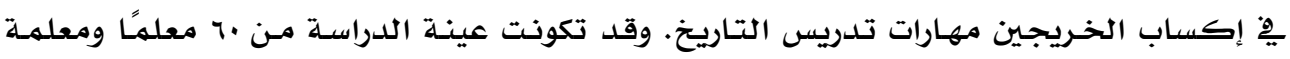

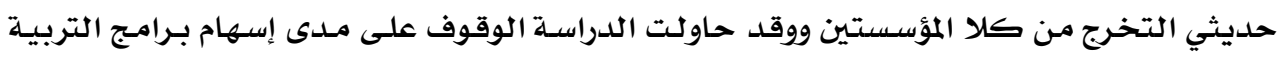

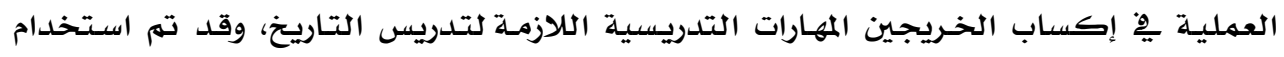

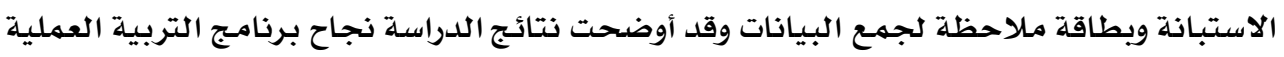

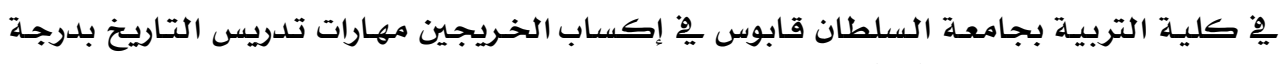

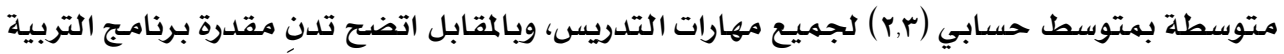

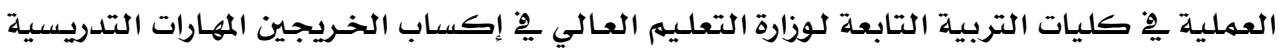

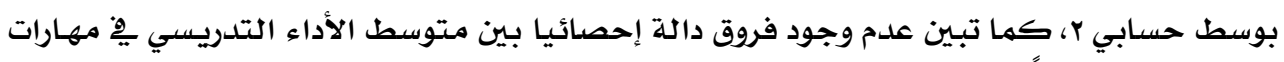

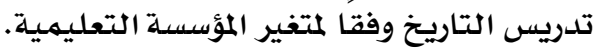
وقام أجرى بيك (Beck, 2002) بإجراء دراسـة هدفت الوقوف على نوع الدعم والتغذيـة

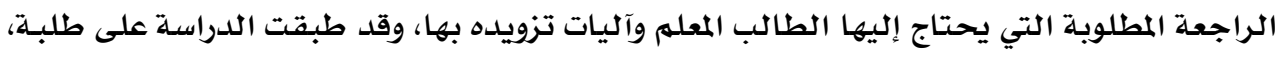

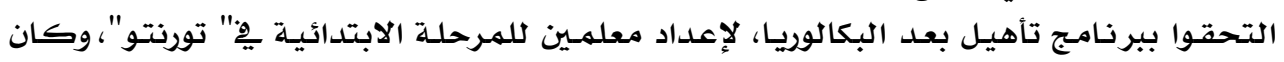

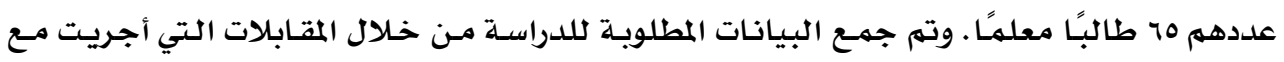

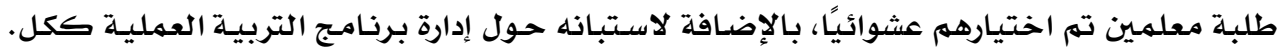

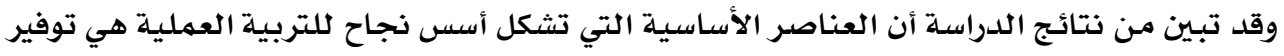

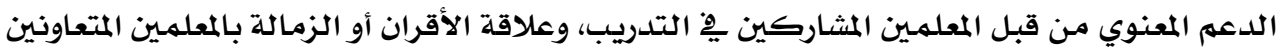

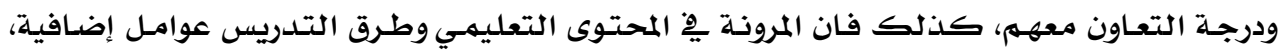

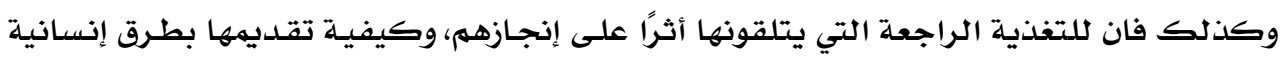


وأخلاقيـة وعمليـة وفهم كل مـا يقال حول التعليهم والتعلم هِ الغرفة الصفية الحقيقيـة، وحجهم

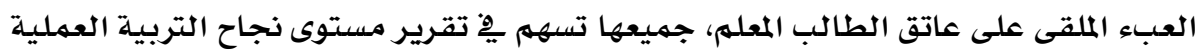

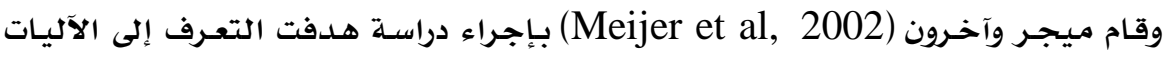

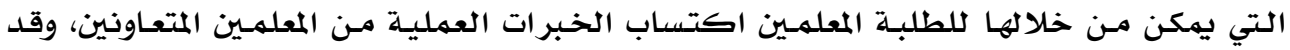

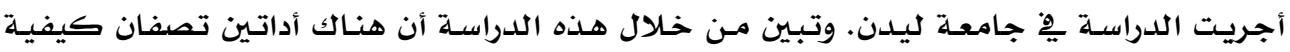

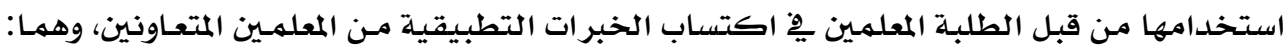

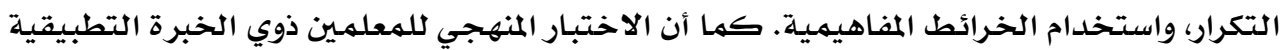

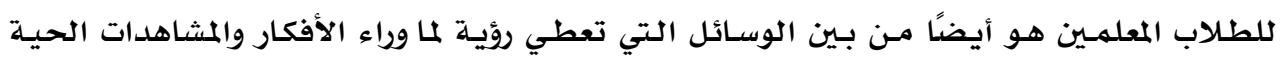

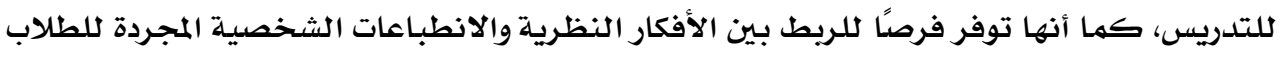

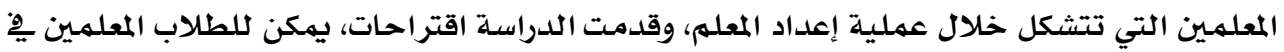

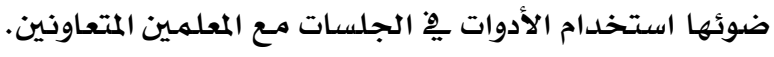

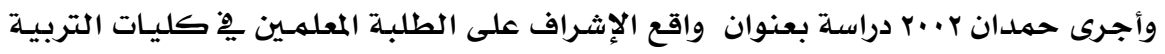

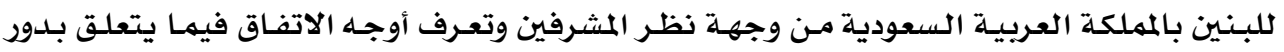

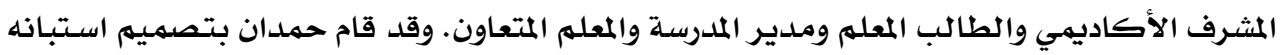

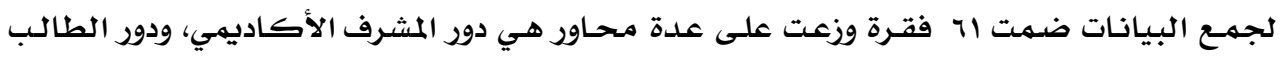

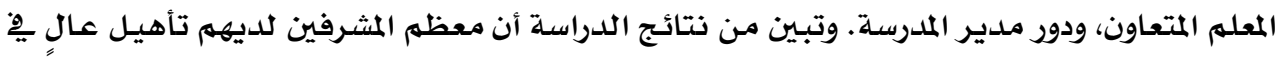

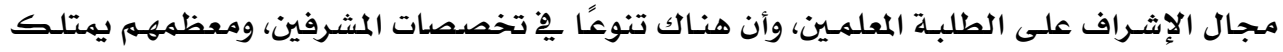

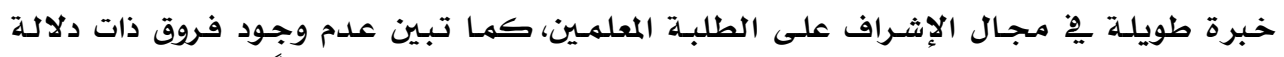

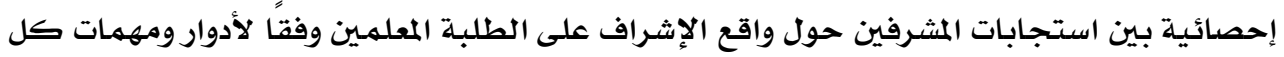

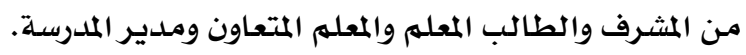

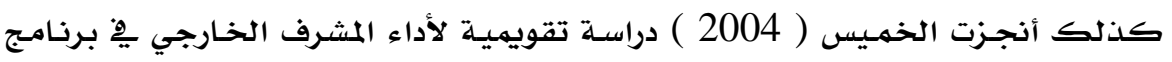

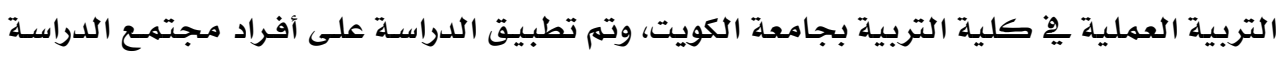

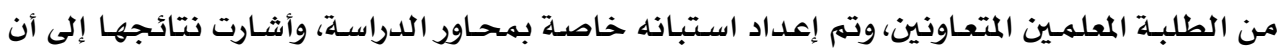

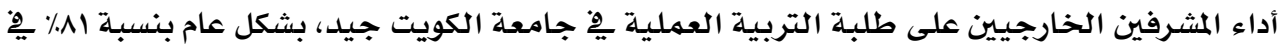

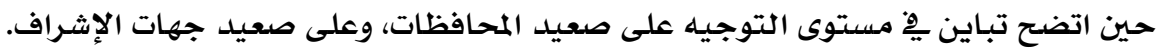

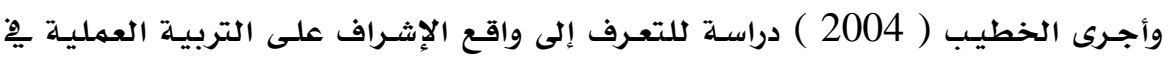

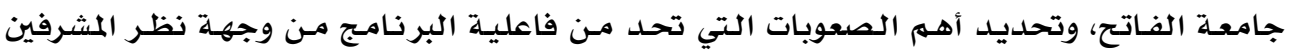

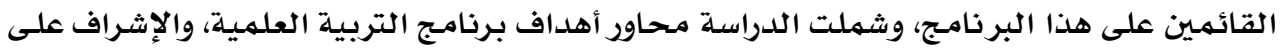

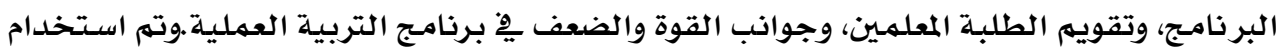

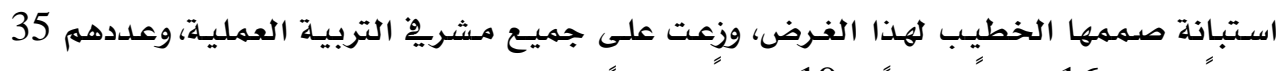

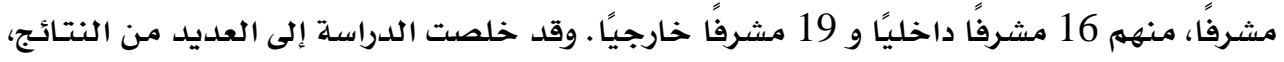

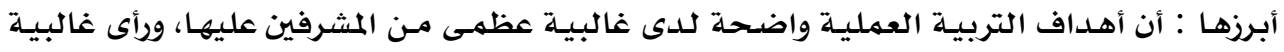


المثرفين أن برنامـج التربية العملية حقق أهدافـه بلدرجـة متوسطة، كمـا لم يتبين وجـود فروق ذات

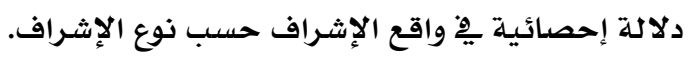

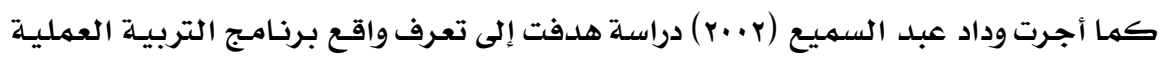

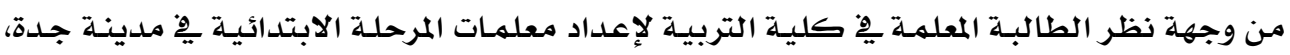

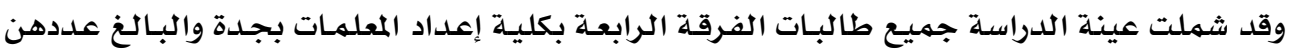

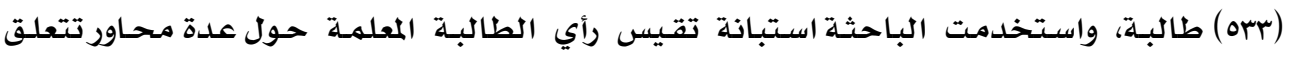

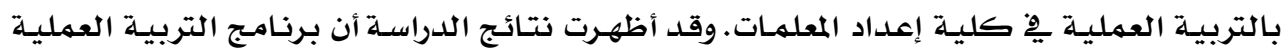

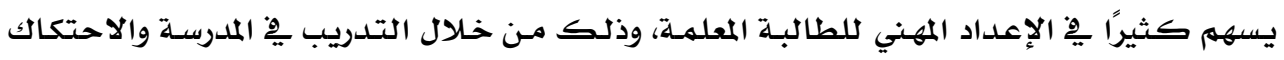

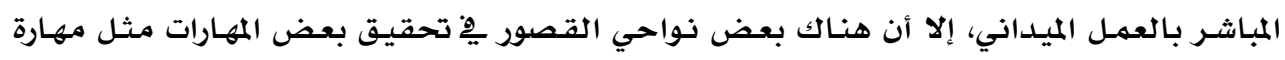

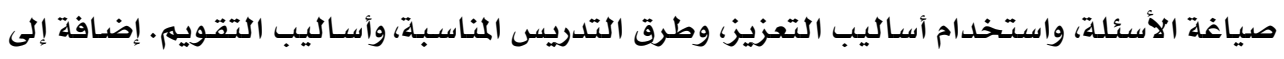

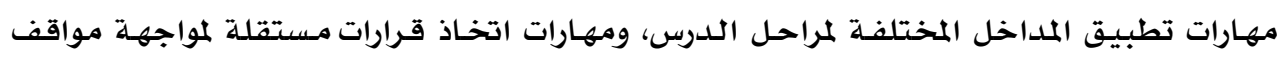

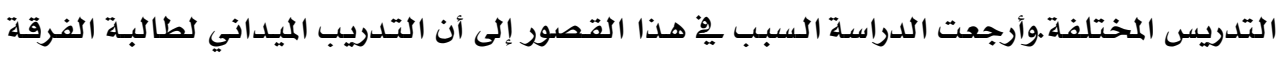

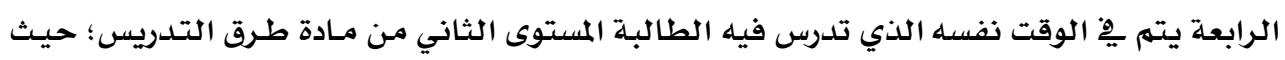

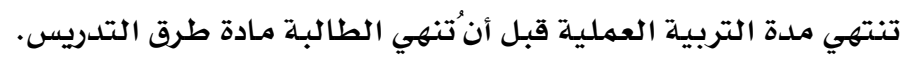

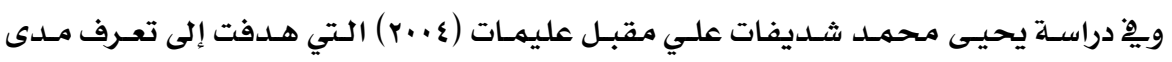

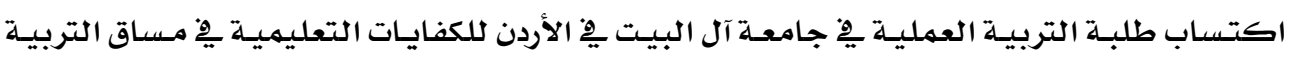

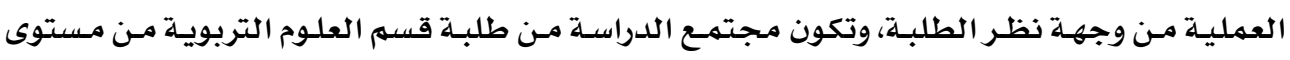

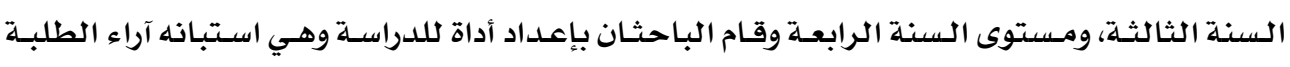

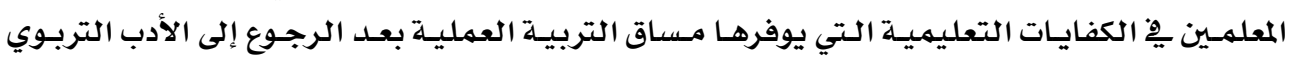

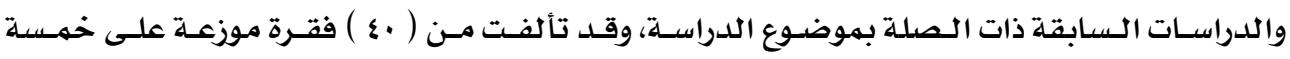

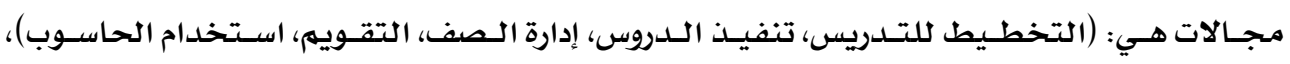

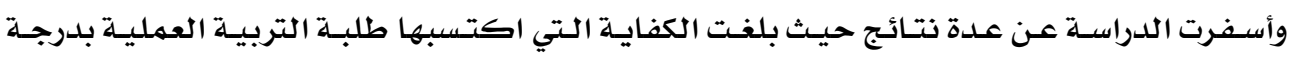

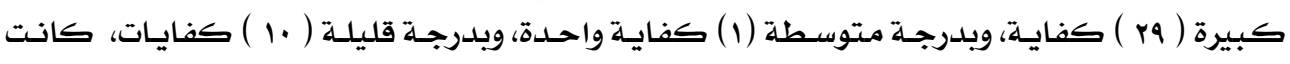

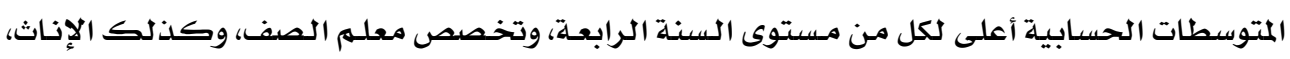

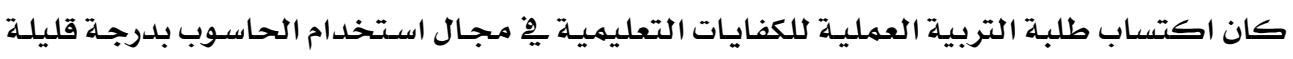

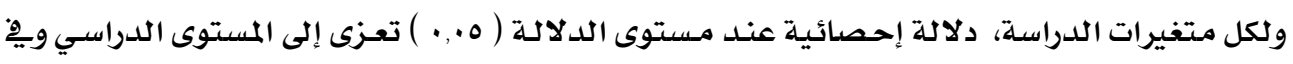

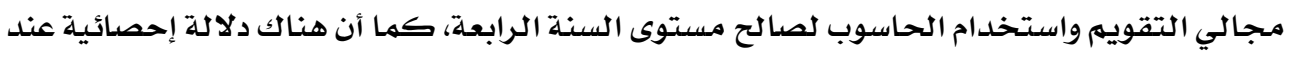

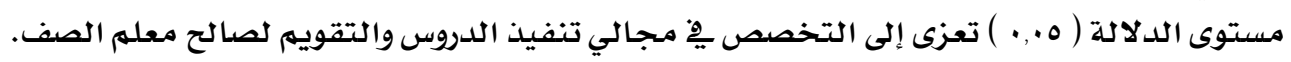

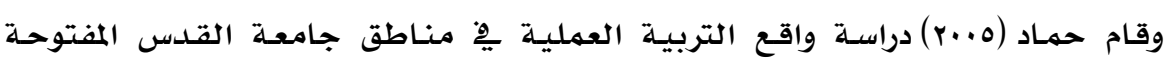

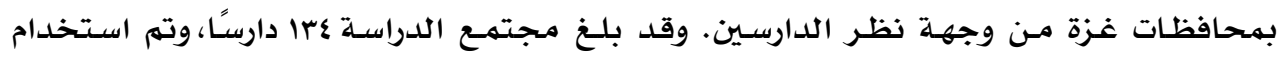

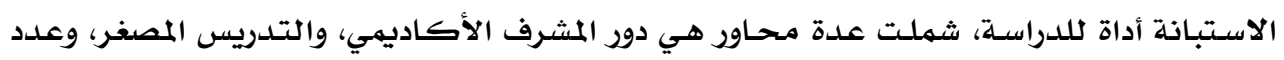

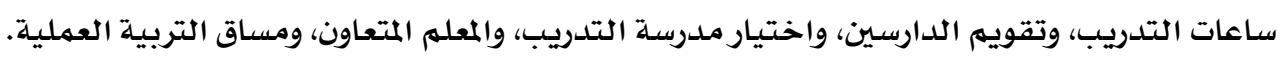


وقد أوضحت الدراسة ايجابية وفعالية دور المشرف الأكاديهي، كما تبين ايجابية التوجه نحو زيادة

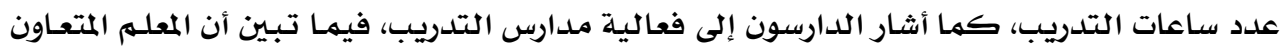

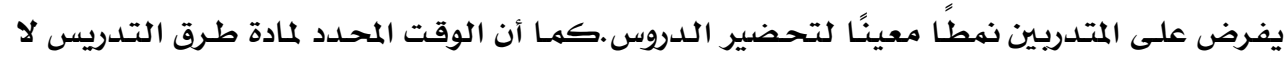

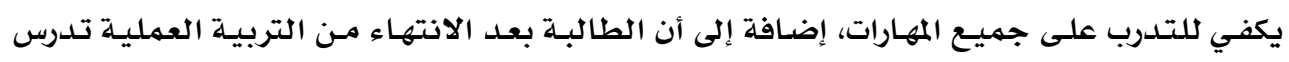

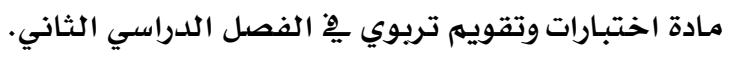

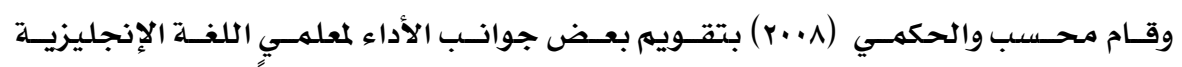

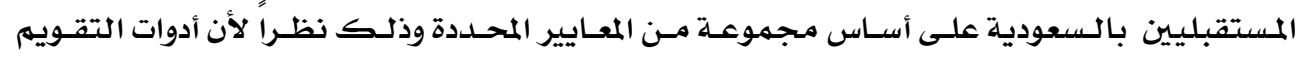

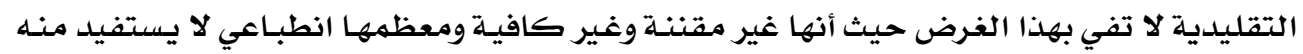

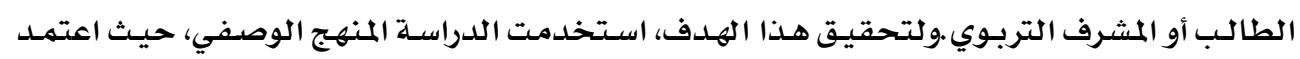

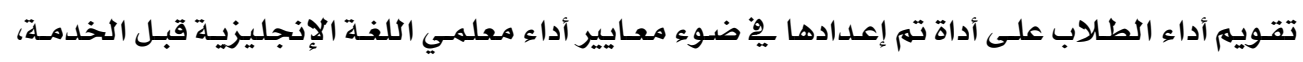

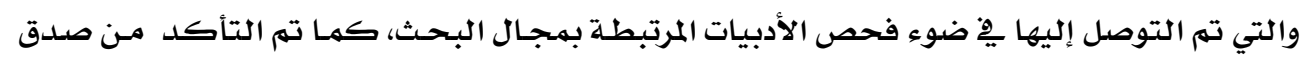

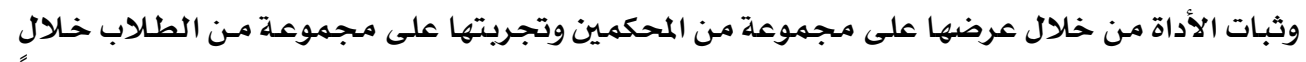

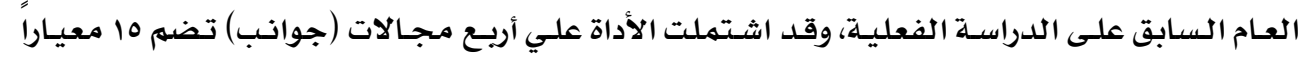

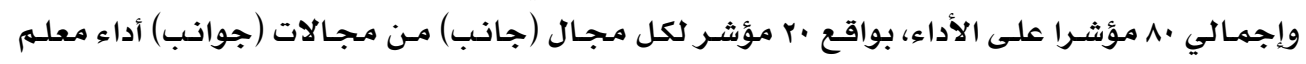

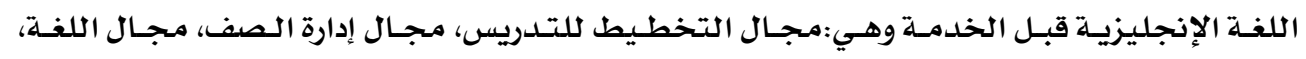

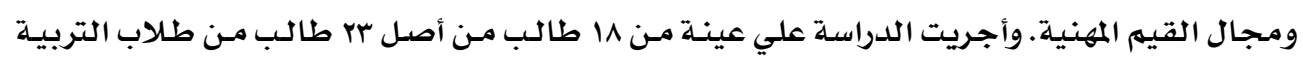

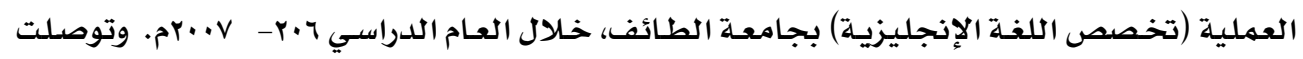

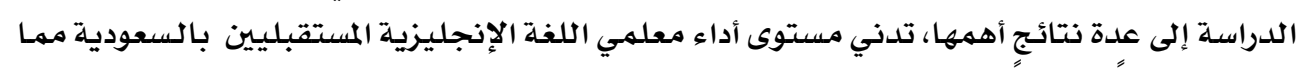

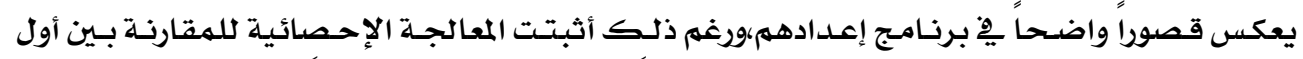

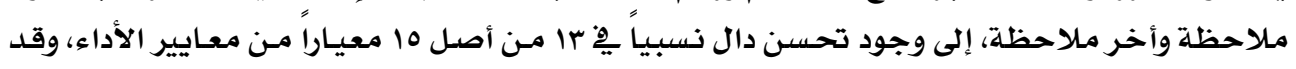

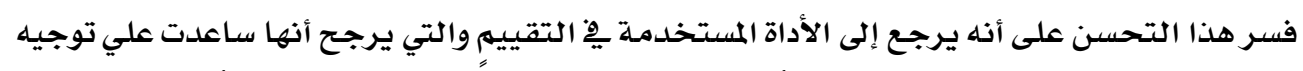

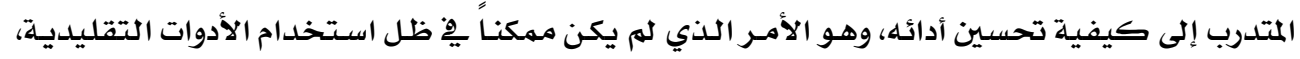

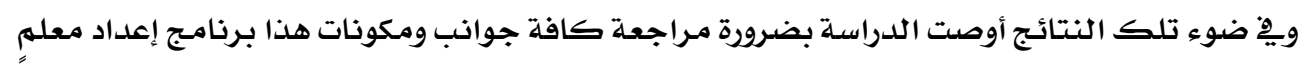

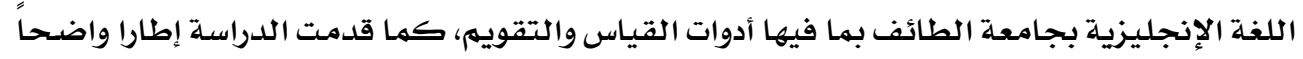

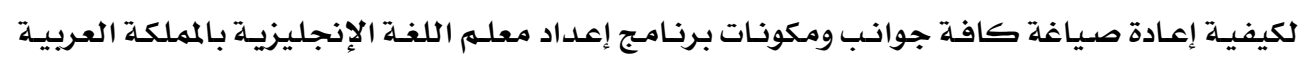

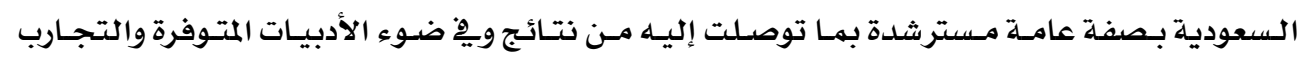

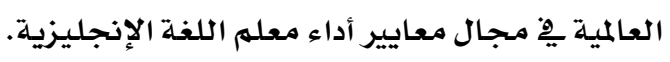

\section{هنهجية الدراسة وإجراءاتها:}

منهج الدراسة: لتحقيق أهداف البحث الحالي اعتمد فريق البحث على المنهج الوصفي التحليلي،

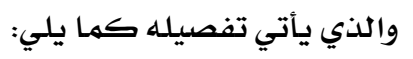

عينة الدراسة: اعتمد فريق البحث ِِّ تحليله لواقع برنامج التربية العملية بكلية التربية جامعة

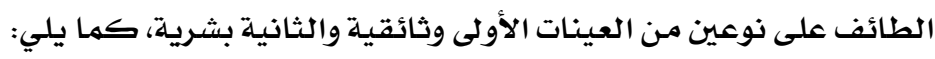


أ. العينة الوثائقية، و التي اشتملت على أدوات ووثائق تقييهم أداء طلاب المعلمـين ِِِ البرنامـج

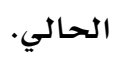
ب. العينة البشرية و التي اشتملت على:

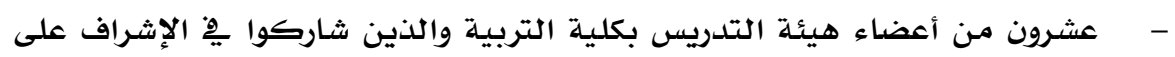

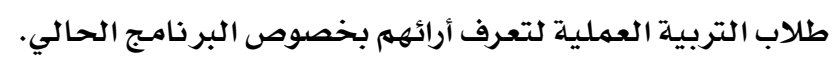

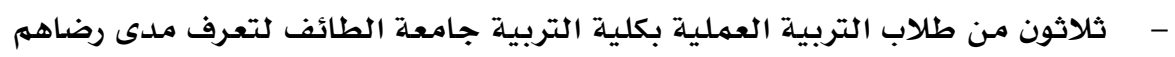

$$
\text { عن البرنامج الحالي. }
$$

\section{إجراءات الدراسة:}

$$
\text { سارت الدراسة وفق الخطوات الآتية: }
$$

ا. الاطلاع على الأدبيات والدراسات والتجارب المحلية والدولية الخاصة بشأن برامج التربية العملية

$$
\text { وأسس تطبيق التعليم المتمركز حول الطالب (الخصائص - الأسس - آلية التتفيذانية ). }
$$

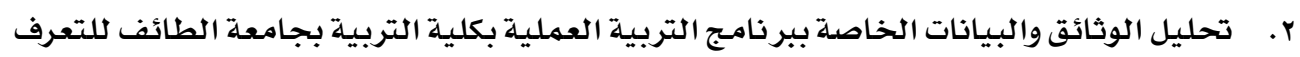

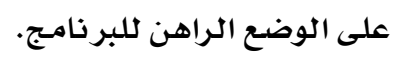

r. إجراء مقابلات شبه مقننة مـع أعضاء هيئة التدريس بكلية التربية والذين شاركواهي

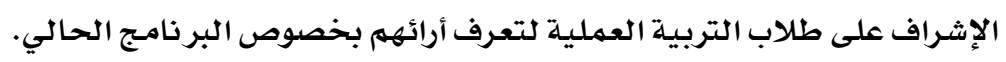

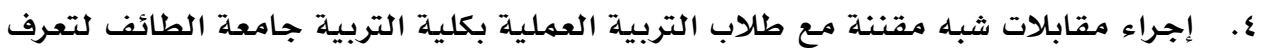

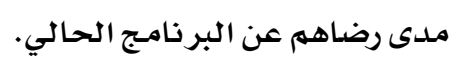

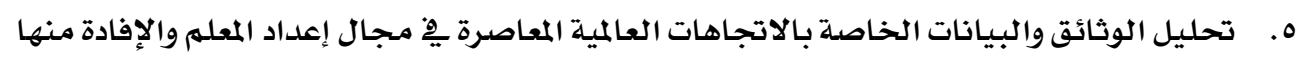

$$
\text { يٌْ تطوير برنامـج التربية العملية. }
$$

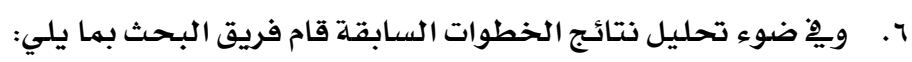

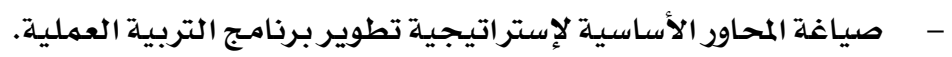

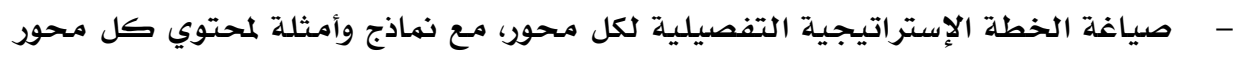

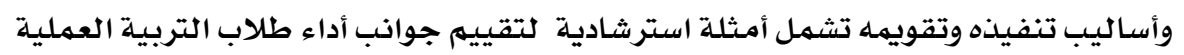

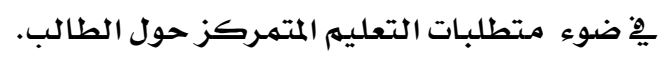

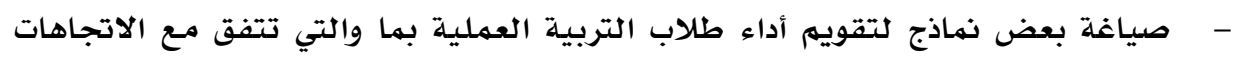

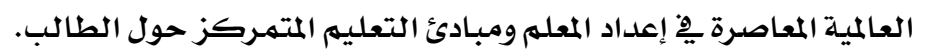

\section{عرض النتائج وهناقشتها:}

$$
\text { مِّْ ضوء الإجراءات السابقة، تم التوصل إلى الآتي: }
$$

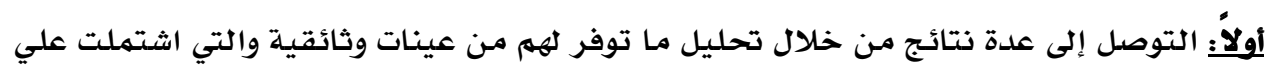

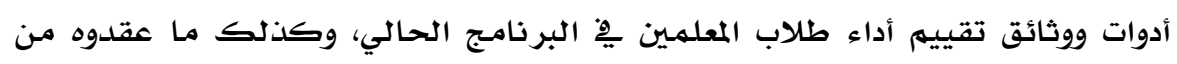

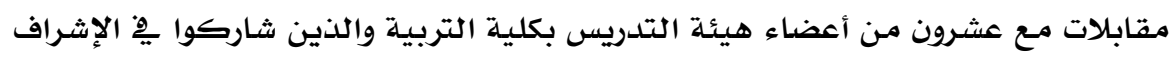

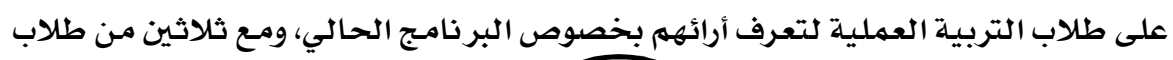


التربية العملية بكلية التربية جامعة الطائف لتعرف مدىى رضاهم عن البرنامـج الحالي،

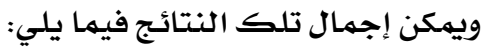

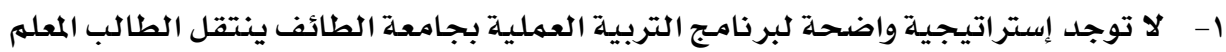

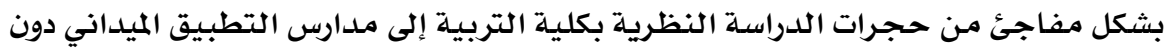

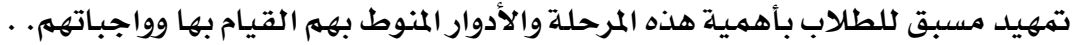

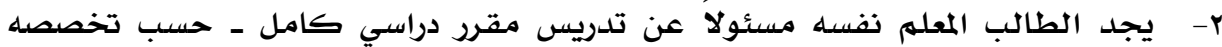

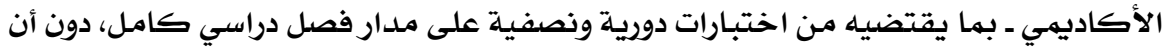

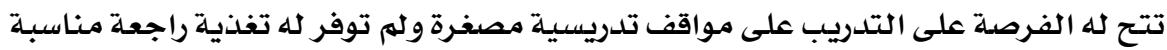

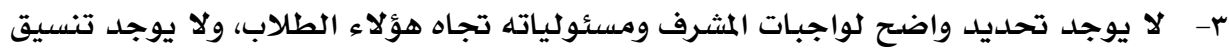

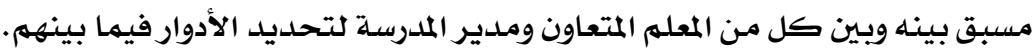
يوجد تحديد بالإضافة إلى مسئوليات وواجبات كل من المعله المتعاون ومدير المدرسسة، تجاه

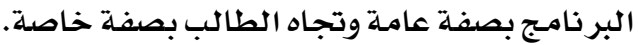

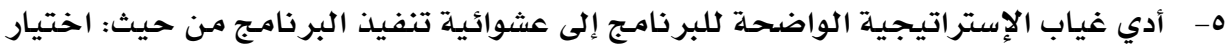

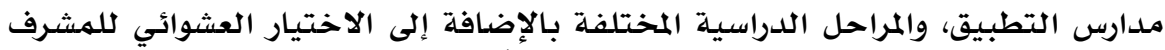

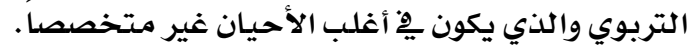

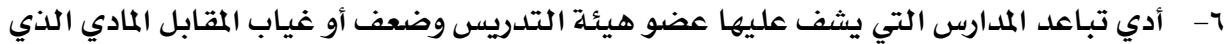

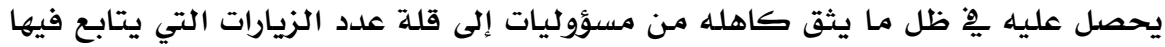

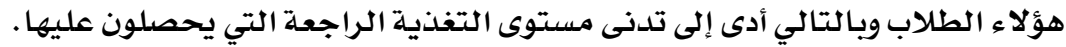

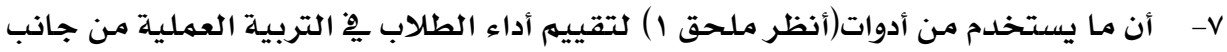

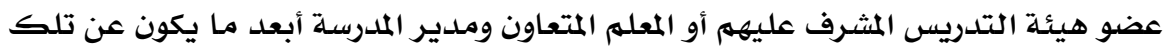

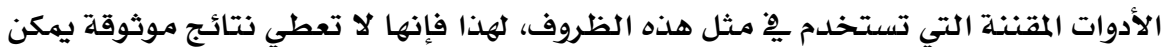

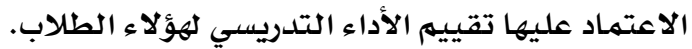

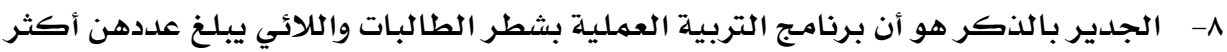

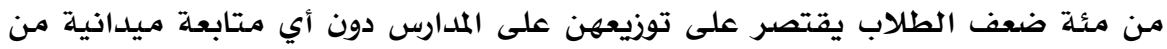

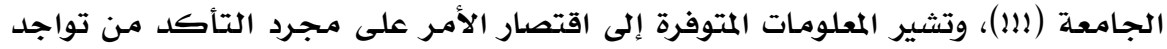

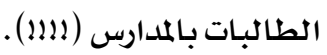

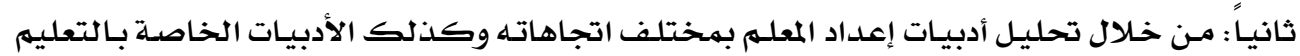

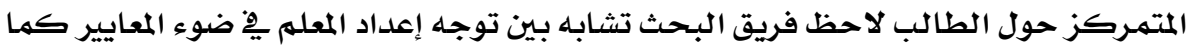

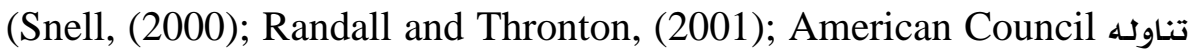
on the Teaching of Foreign Languages (ACTFL), (2002), McCloskey et al., (2003); Glass, (2004) ; and Borman and Kimball, (2005); وبين ما تناولته أدبيات التعليهم Morton, (2005); Mohasseb and Hakami (2008)

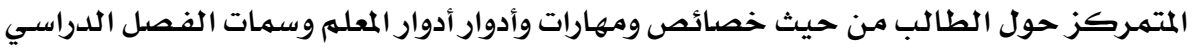


Oِّ هـا النوع مـن التعليه، وخـاص: O Ohashi \& Ohashi (1993); Tudor (1993); Norman Spohre (1996) ; Grunert (2000); Altan \& Trombly (2001); Weimer. (2002); Brown (2003).Hewett (2003); Ludmerer (2004) Doyle (2007); Jeffrey (2009) Normandy (2009); Flint (201.

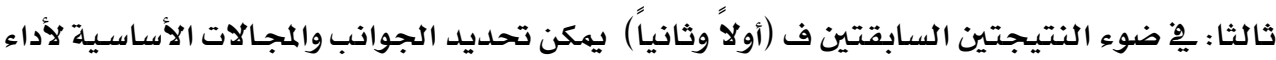

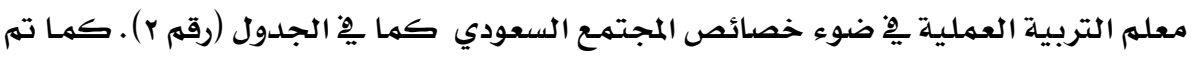

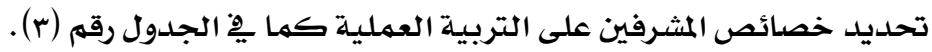
جلدول (رقم r) جوانب ومجالات أداء معلم التربية العملية ومؤشرات العمات نجاحها

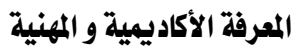

التمكن من وفهم طبيعة البنية المعرفية لمادة التخصص (حقائق - مفاهيم - تعميمات - مهارات).

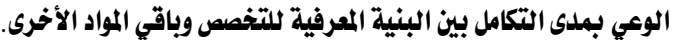

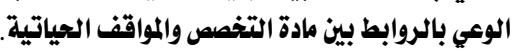
الإلمام بخصائص مرحلة نهو التلميذ وخبراته، ومواهبله، وتعلمه السابق وثقاقته، وجنسه وأسرته ومجتمعسه وتأثير ذلـك كلـه على تعلمه.

مراعاة الفروق الفردية بين تلاميذه: الجسمية والفعلية والاجتماعية.

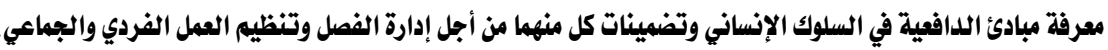

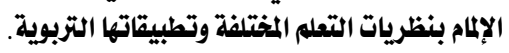

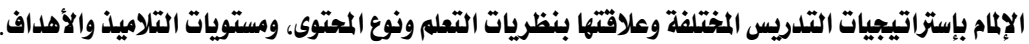

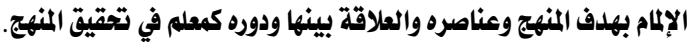

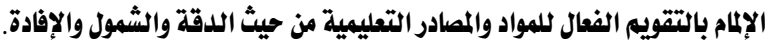
الإكام بأدوات قياس جوانب التعلم وكيفية استخدامها والاستفادة من تتائجها في عمليات التقويم. التخطيط للتدريس الإلمام بمفهوم التخطيط ومستوياته وشروط التخطيط الجيد.

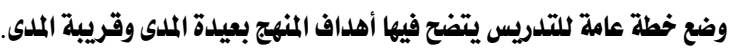

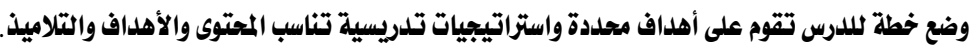

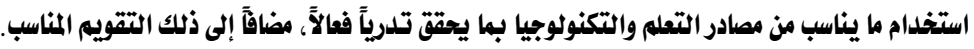

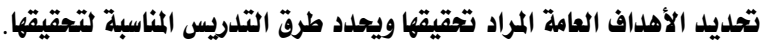

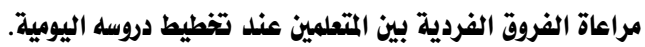
تنظيم موضوع اللدرس تنظيما منطقيا حتى يسهل تعلمهي.

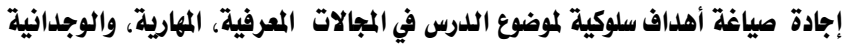

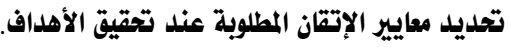

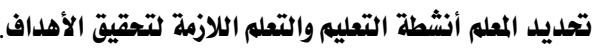

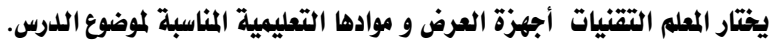

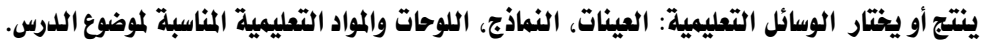
يحدد أساليب التقويم المناسبة موضوع اللدرس.

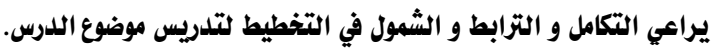

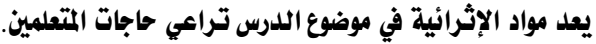
يهيئ البيئة الصفية التي تناسب تلدريس الموضوع. 


$$
\text { تنفيذ التدريس الفعال وإدارته }
$$

$$
\begin{aligned}
& \text { - - يوفر بيئة مشجعة للتعلم. }
\end{aligned}
$$

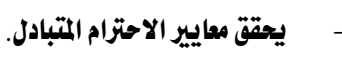

يلدير الفصل إدارة فعالة.

يشجع التلاميذ على إظهار الانضباط الذاتي والمسئولية عن الذات وعن الآخرين.

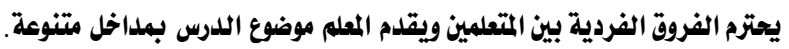

$$
\text { ييسر عمل التلاميذ سوياً بشكل متعاون ومنتج. }
$$

يشجع الشاركة الفعالة في الفصل الدراسي.

يستمع إلى آراء التلاميذ ويفكر فيها ويستجيب إليهيه.

يطبق أخلاقيات المهنة في الممارسات اليومية.

يربط التعلم بخبرات التلاميذ ومعرفتهم السابقة.

يربط بين محتوى اللدرس والمواقف الحياتية في الوقت المناسب.

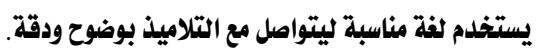

يستخدم العديد من الإستراتيجيات التدريسية الفعالة ليشرك التلاميذ بنشاط في التعله.

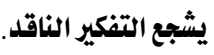

يستخلم مصادر التعلم المختلفة بشكل مناسب.

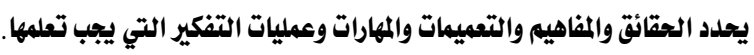

يوفر فرصاً للتلاميذ كي يستخدموا ويمارسوا ما تعلموه.

يعدل في تدريسه بناء على التفذية الراجعة من تلاميذه.

$$
\text { يحقق الأهداف بمستويات مرتفعة. }
$$

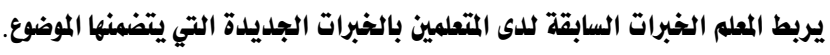

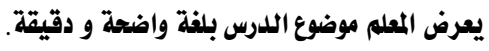

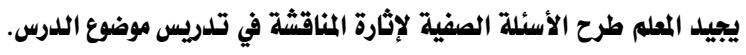
يتدرج المعلم في عرض الموضوع منطقيا وسيكولوجياً. يوظف المعلم أساليب إدارة الفصل بفاعلية في تلدريس الموضوع.

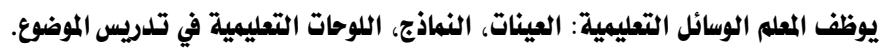

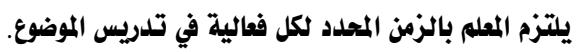

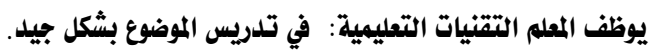

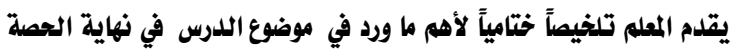




\section{التقويم تصيم}

يفهم خصائص واستخدامات الأنواع المختلفة من المقاييس لتقييم تعلم التلاميذ.

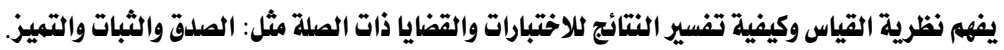

يصمه أدوات مختلفة للقياس. يقوم مصادر المنهج من حيث : الدقة والشمول والإفادة.

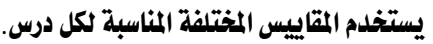
يشخص نقاط القوة والضعف بناء على تحليله لنتائج المقاييس المختلفة. يقدم تفذية راجعة مناسبة لكل من التلاميذ والآباء. يشجع التقدير الذاتي للتلاميذ.

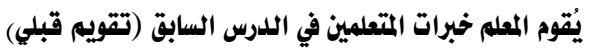

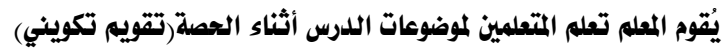

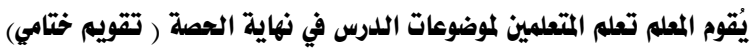

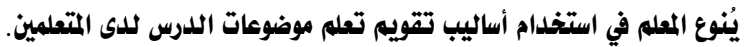

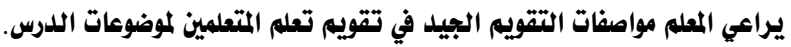

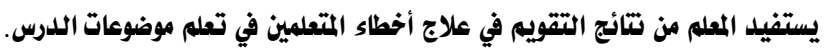

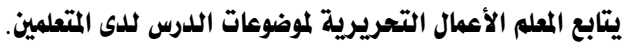

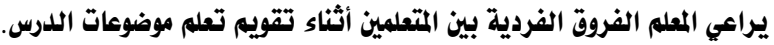
يوظف المعلم التقنيات التعليمية في تقويم تعلم موضوعات اللدرس للدى المتعلمينين. يوظف المعلم التفذية الراجعة في تحسين تعلم موضوع اللدرس للدى المتعلمين. يشجع المعلم المتعلمين على التقويم الذاتي. يجيد المعلم وضع الاختبارات التحصيلية لتقويم تعلم موضوع اللدرس للدى المتعلمين. يستفيد المعلم من تتائج التقويم في تعديل أدائه.

\section{الالتزام بمتطلبات النهو المهني}

يراجع ممارساته ويقيم تأثيراتها على نمو تلاميذه وتعلمهه.

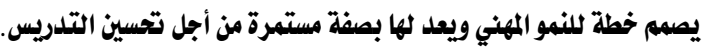

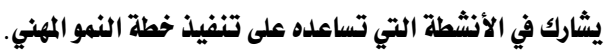

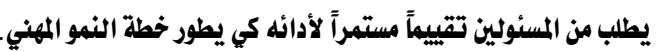
يستخدم الوسائل التكنولوجية في تنميته المهنية.

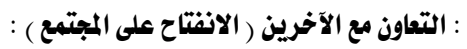

يعمل مع الآباء لكي يحسن تعلم التلاميذ في المنزل والمدرسة. يتعاون مع زملائه ليحقق أهداف المدرسة والمجتمعي. يمتلك مهارات القيادة وعضوية الفريق التي تيسر تحقيق الأهداف المنشودة. يتعاون مع المهنيين الآخرين والمؤسسات الأخرى ليحسن بيئة التعلم. يلم بالنظام التعليمي وعلاقته بالمجتمع ومؤسساته المختلفة وكيفية التعامل معها بما يخدم مهنته. 


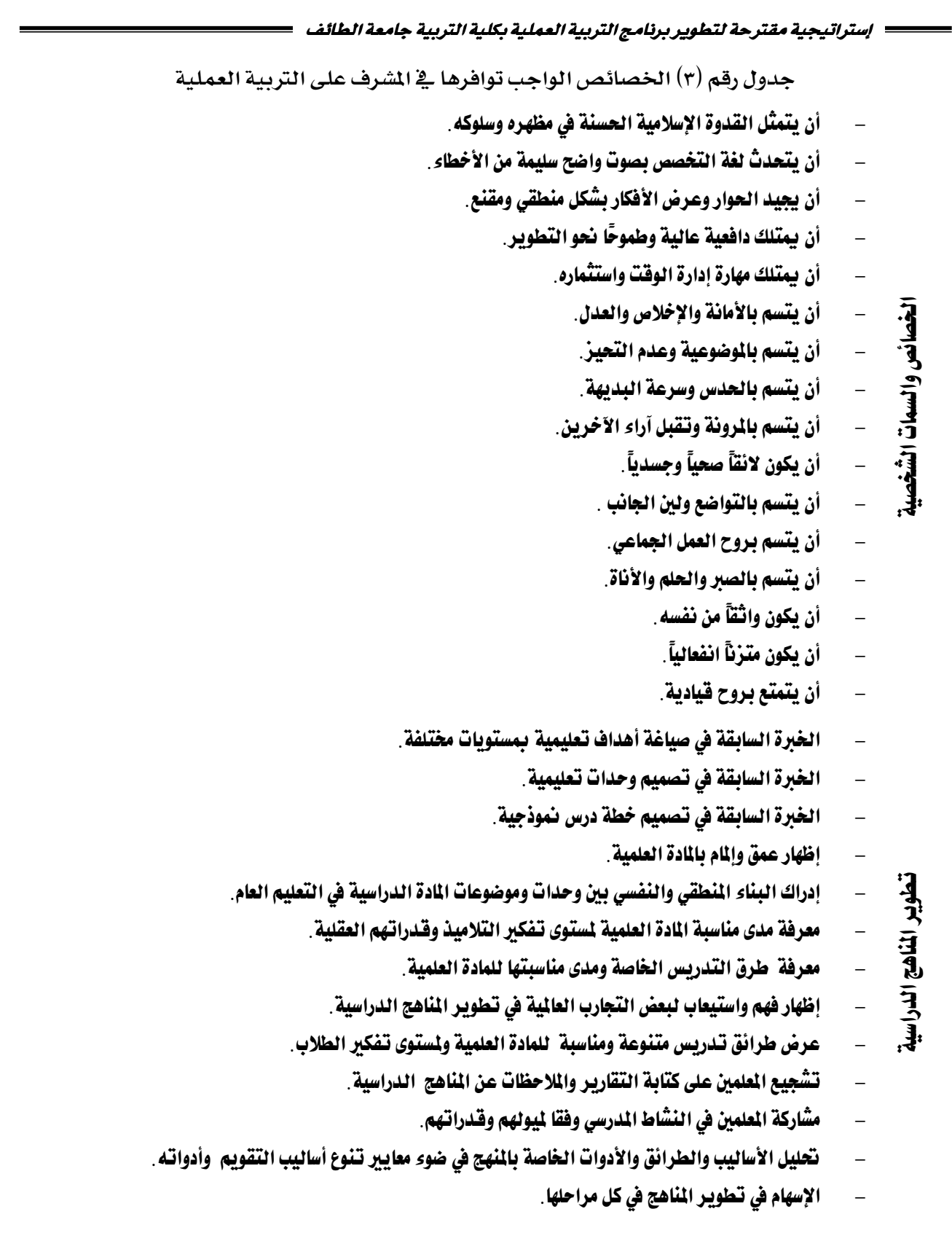


تحديد احتياجات البرامج التعليمية القائمة.

التحليل الدقيق لأوجه للتعارض بين الواقع وما ينبفي أن تكون التولية عليه الأنشطة التعليمية.

$$
\text { اختيار المواد المعينة على التعليم والتعلم. }
$$

تقويم المواد المعينة على التعليم والتعلم.

تحديد درجة الاتتفاع من مصادر التعلم.

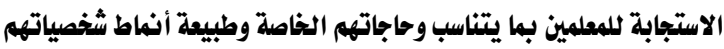

تحليل احتياجات الطلبة.

فهم دور التعليم في مقابلة احتياجات الطلبة.

جلدولة الخدمات الخاصة التي يحتاجها الطلبة.

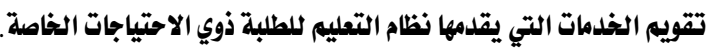

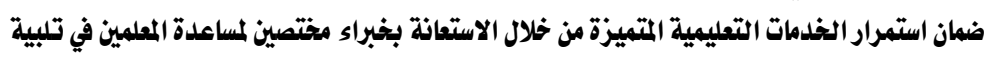

احتياجات الطلبة الخاصة.

التعرف على الطلبة من ذوي الاحتياجات الخاصة.

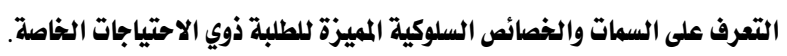

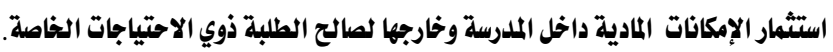

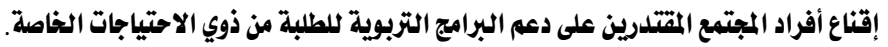

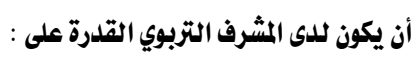

إجراء تعديل في الأنظمة التعليمية القائمة.

فهم البرامج التعليمية القائمة واستيعابها.

فحص البرامج والتنظيمات التربوية الجديلدة والحكم على مدى صلاحيتها.

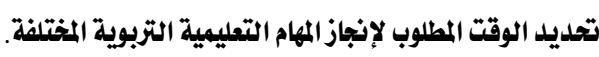

تحديل مصادر تحسين مستوى كفاءة العملية التعليمية.

تقويض الصلاحيات ومنح المسؤوليات وفق خطة واضحة المعاله.

اتخاذ القرارات في المواقف التعليمية المتباينة.

تنظيم الاتصال بين المدرسة واللوائح المنظمة للعمل.

توعية المعلمين بنظام الملدرسة واللوائح المنظمة للعمل.

تنمية شعور المعلمين بأهية الالتزام بمواعيد العمل الرسمي. 
إستراتيجية مقترحة لتطويربرنامج التربية العملية بكلية التربية جامعة الطائف

وضع خطة شاملة لتحديد احتياجات العملية التعليمية من القوى البشرية.

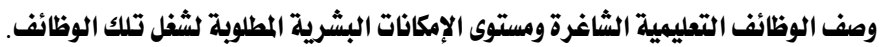

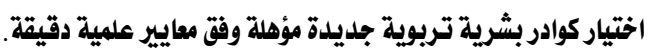

استخدام حلقات الإشراف العيادي بفاعلية.

استخدام أسلوب التفذية الراجعة لتحسين عمليتي التعليم والتعلم.

وضع خطة لتحسين سلوك المعلم.

وضع خطة واضحة لتنمية المعلم كفرد وتطوير قدراته وإمكاناته.

وضع تصور محدد لتحسين ممارسة المعلم لعملية التعليم و التعله.

تصميه برنامج تدريبي متكامل العناصر لتطوير قدرات المعلمين وإمكاناتهم العلمية والمهنية.

تنفيذ البرامج التدريبية وإدارتها.

تمتابعة خريجي البرامج التدريبية وأثر تلك البرامج في أداء الخريجينين.

تصميه حقيبة تدريبية يستخدمها المعلم في التدريب الذاتي.

تصنيف المعلمين حسب قدراتهم العقلية.

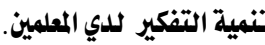

تشكيل فرق متجانسة من المعلمين لممارسة أسلوب الإشراف التبربوي التعاوني.

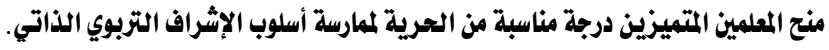

تنمية التفكير المستقل لدى المعلمين من خلال بناء قدراتهم على تحليل أعمالهم بأنفسهم وابتكار طرق تلدريس

جلديلة.

التخطيط للمداولات الإشرافية الفردية مع المعلم.

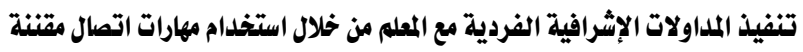

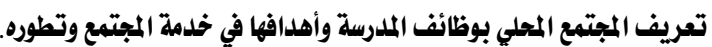

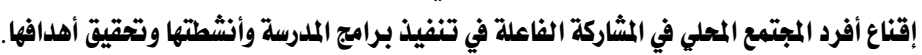

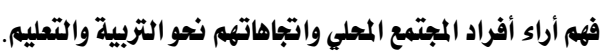

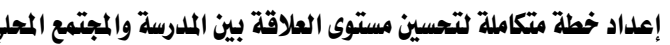

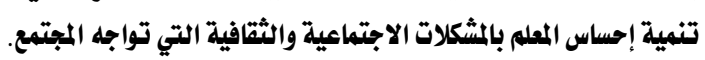

الشاركة الفاعلة في اجتهاع مجالس الآباء والمعلمين.

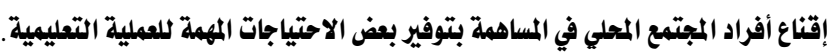

التفلب على بعض العقبات التي تعيق استفادة المجتمع المحلي من المبنى الملدرسي. 


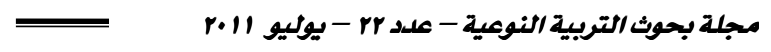

العمل التعاوني الفعال مع المعلمين في تحقيق أهداف العملية التعليمية.

حل الشكلات التي تواجه المعلمين.

التواصل اللفظي مع الآخرين بفاعلية.

التعامل مع المواقف السلبية بفاعلية.

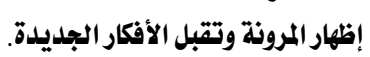

توثيق العلاقة بين المخططين والمنفذين لعملية التعليد.

التواصل الكتابي مع الآخرين بفاعلية.

الإصفاء الجيد أثناء التفاعل اللفظي مع الآخرين.

تمييز مدلولات السلوك غير اللفظي للآخرين في المواقف التعليمية المختلفة.

تهيئة أجواء تعليمية حرة لتسهيل عمل المعلمين وتقبلهم للتقويم البيّاء.

بناء علاقات طيبة مع جميع المعلمين.

فهم طبيعة السلوك الإنساني ودوافع ورغبات المعلمين.

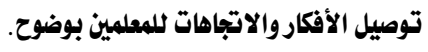

مراعاة الفروق الفردية بين المعلمين.

استخدام أدوات وأساليب التقويم المختلفة.

تطوير أدوات القياس والتقويم المختلفة.

كتابة التقارير لنقل تتائج عملية التقويم للمعنيين بها.

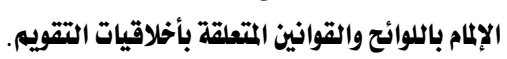

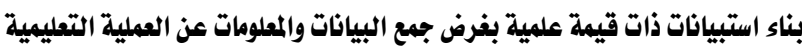

إجراء المقابلات الشخصية المقننة.

تحليل وتفسير البيانات من خلال استخدام الأساليب الإحصائية.

تحديل مستوى التطور والتحسن في التحصيل للدى الطلبة.

高

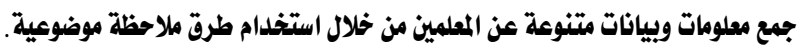

تقييز سلوك المعلم أو المدير المتحيز لطالب أو فئة ما من الطابلاب.

تقويم الأنشطة التعليمية الصفية وغير الصفية. 


\section{إستزاتيمية هقتزحة لتطوير برناهج التزبية العمبلية بماهعة الطائف في ضوs هتطبات التمايسم المتهركز هول الطالب}

فِ ضوء الدروس المستفادة من تحليل الوضع لبرنامج التربية العملية بجامعة الطائف، وبهـا

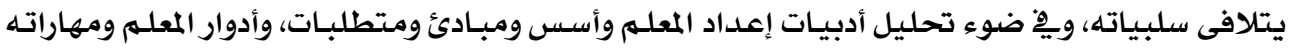

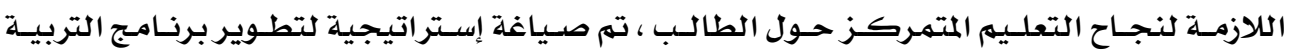

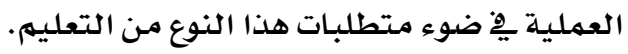
أولاً: محاور الإستراتيجية المقترحة:

تقوم الإستر اتيـجيـة المقترحة إستراتيـيـة لتطـوير بـرنـامـج التربيـة العمليـة بجـامعـة الطـائف

$$
\text { ِِغ ضوء متطلبـات التعليهم المتهمركز حول الطالب على محورين أساسيين: }
$$

المحور الأول: ويعتمد على توعية الطلاب المعلمـين من خلال مجمهوعـة مـن المحاضـرات وحلقـات النقـاث حول الأسس والمبـادئ النظريـة للتعلـيه المتمـركز حـول الطالب بهـا يخ ذلك أدوار وسهـات ومهارات المعلم يْ هذا النوع مـن التعلـيه، ويلـي كل محاضـرة سلسلـة ورث عمل للتـدريب على مـا تناولتته المحاضـرة من مبادئ نظريـة. المحور الثاني: ويعتمد على:

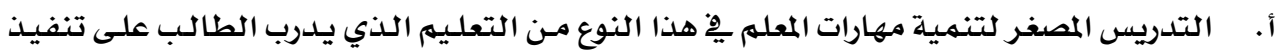
ما اكتسبـه مـن معلومات ومعارف نظريـة يخ مقررات المناهـج وطرق التدريس، تكنولوجيـا التعلـيهم

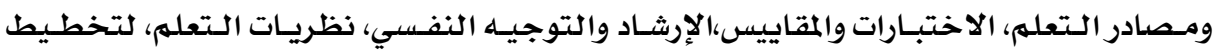
وتنفيـه و تقـلـيهم الأنشطة التعليميـة وإدارة الصف واستراتيجيـات وأسـاليب التـدريس، وأسـاليب

$$
\text { قياس وتقويه الأداء. }
$$

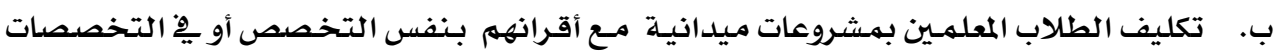

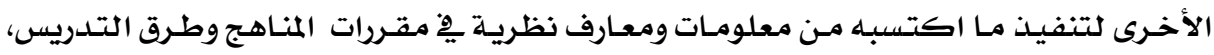
تكنولوجيـا التعلـيهم ومهـادر التعلهم، الاختبـارات والمقاييس،الإرثـاد والتوجيـه النفسي، نظريـات

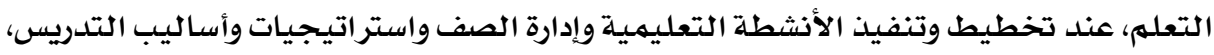

$$
\text { وأساليب قياس وتقويهم الأداء. }
$$

\section{ثانيا: مراحل تنفيذ الإستراتيجية المقتزحة}

1. اختيار المشرفين علي البرنامج وفق الخصائص الواردة يْ الجدول رقمى (r).

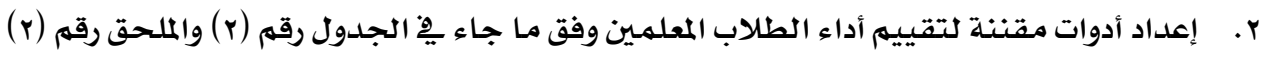

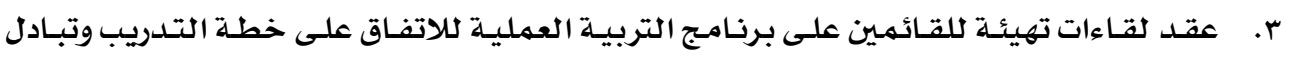

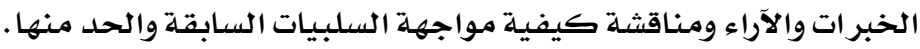




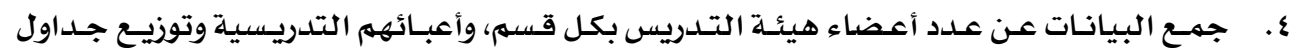

الإشراف غي ضوء ذلك.

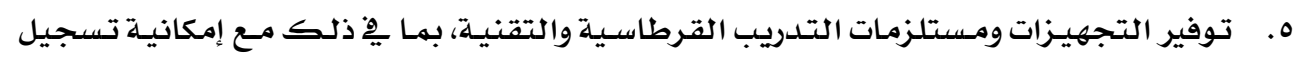

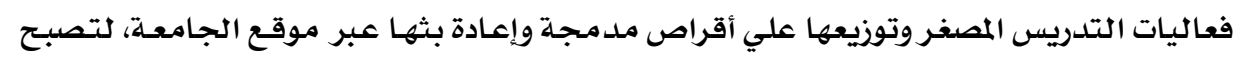
متاحة أمـام الطلاب على مدار الستاعة.

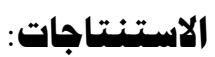

يُستخلص من عرض ونتائج الدراسة الحالية ما يلي:

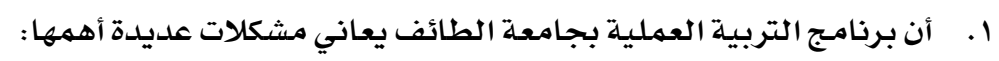

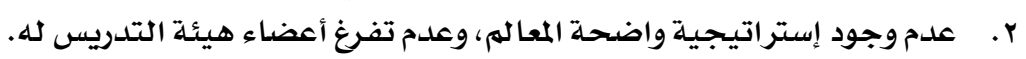

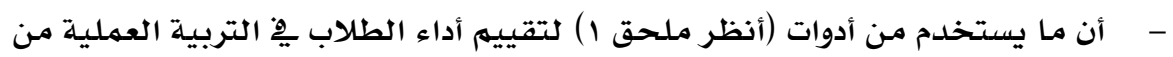

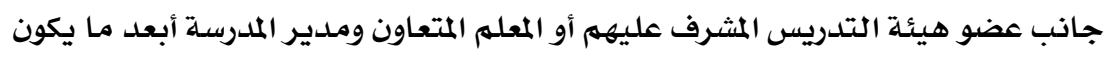

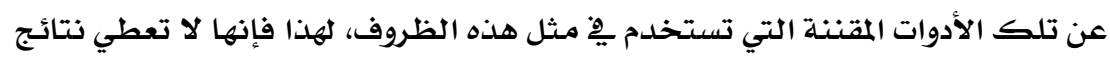

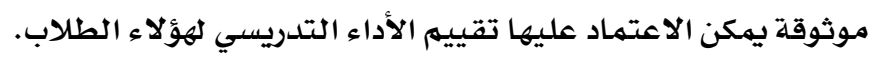

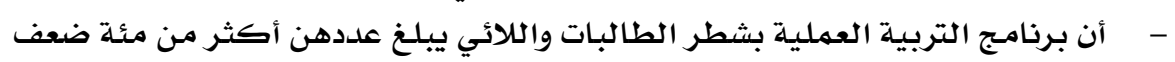

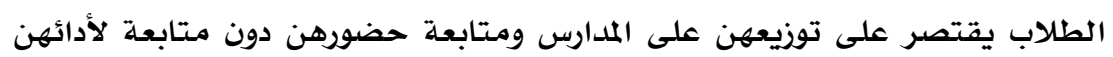

$$
\text { بالفصول. }
$$

r. أن التعليم المتمركز حول الطالب ما سمي كذلك إلا لأنه يضع الطالب وخصائصه

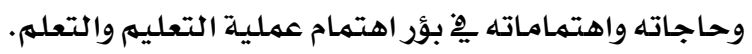

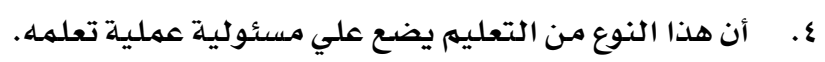

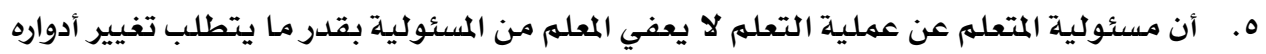

$$
\text { ومسئولياته. }
$$

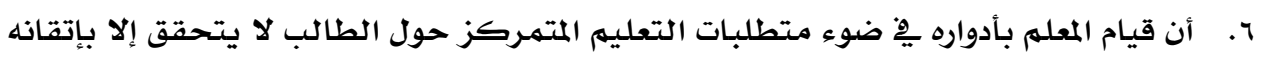

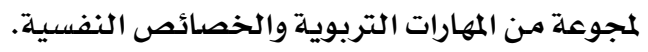

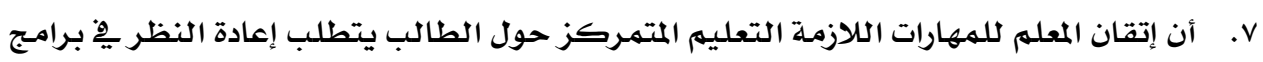

$$
\text { واستراتيجيات إعداده وتدريبـه. }
$$

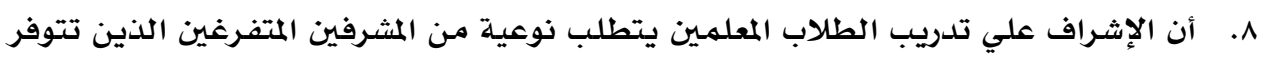

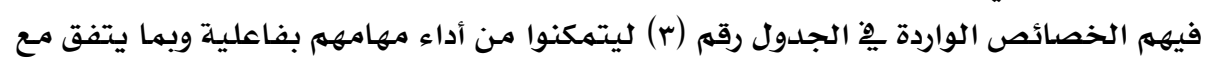
متطلبات التعليم المتمركز حول الطواردة الجدول رقبه 
هِْ ضوء مـا توصلت إليه الدراسـة مـن نتائج واستتنتاجات سـبق عرضها ومناقشتها فـان الدراسـة توصي بما يلي:

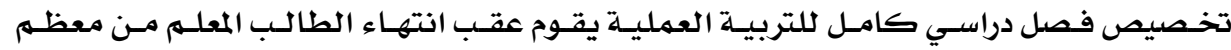

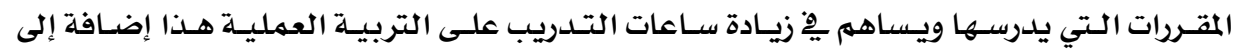
استمرارية التدريب حتى يتمكن الطالب المعلم من المهارات التدريسيسية.

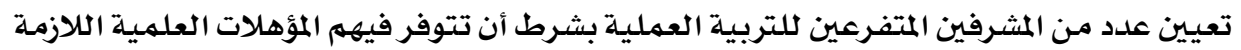

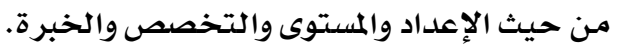

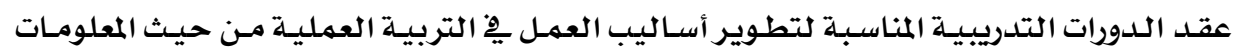
والكفاءات ونظم الإثراف.

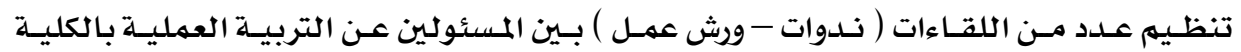

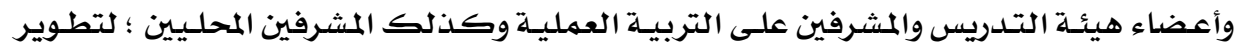
محتوى التربية العملية وأساليبها.

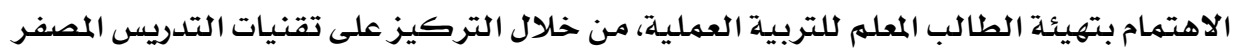

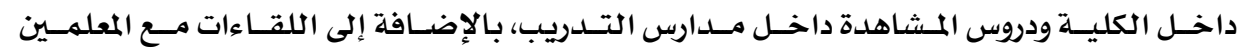
الأكفاء.

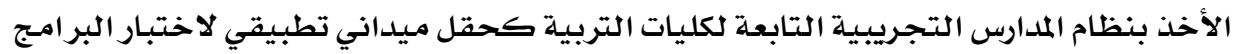

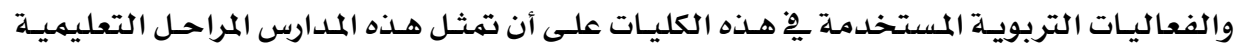
المختلفة.

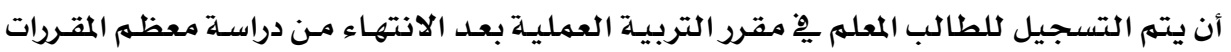

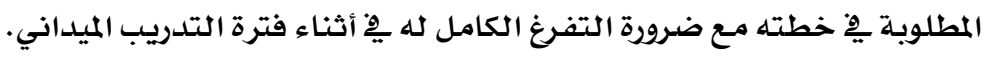

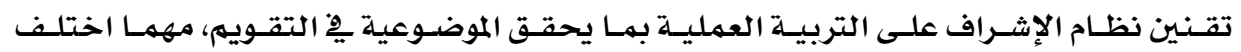

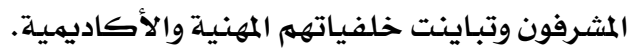

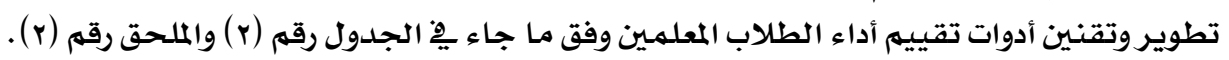

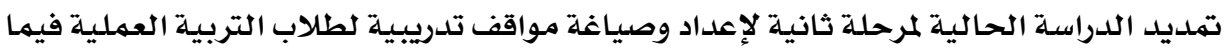

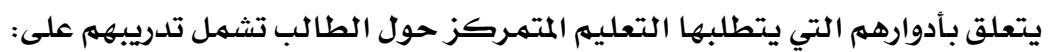

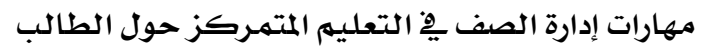

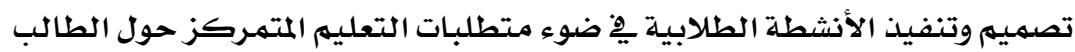

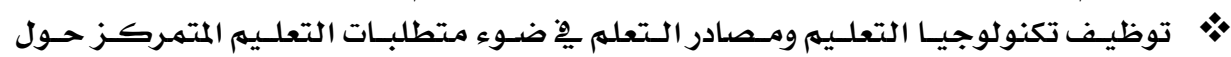

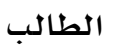
تقويم الأداء الطلابي ِِّ ضوء متطلبات التعليم المتمركز حول الطالب. التدريس الناقد.

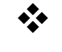

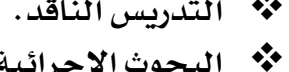

$$
\begin{aligned}
& *
\end{aligned}
$$




\section{ألاًا: المراجع العربية}

ا. أحمد عبد الفتاح الزكي ( 1999 ) : نظام مقترح لإعـداد معلهم المرحلـة الابتدائيدة، دراسـة مقارنة، رسـالة

ماجستيرغير منشورة، كلية التربية بدمياط، جامعة المنصورة.

r. أحمد عبد الله حمد المصلحي .(1990 ) تقويم أداء الطلبة المعلمـين المتخصصين يِّ التربيـة الإسـلامية ببرنامج التربية الإسلامية .رسالة ماجستير غير منشورة، جامعة السلطان قابوس.

r. تركي ذياب ( 1999) ). ميول الطلبـة المعلمـين نحو برنامـج التربيـة العمليـة ِِّ الجامعـة الأردنيـة، دراسـة

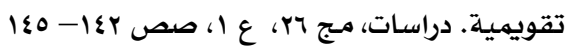

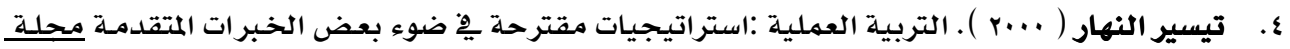

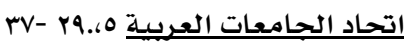

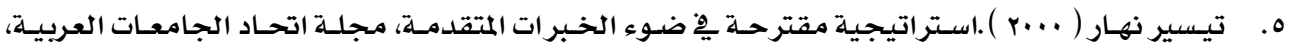

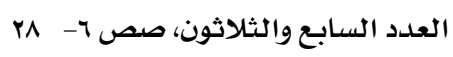

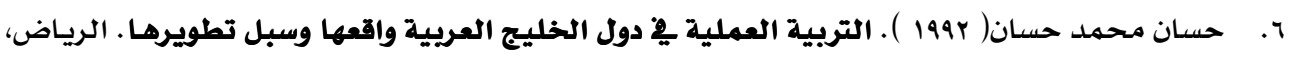

$$
\text { مكتب التربية العربي لدول الخليج. }
$$

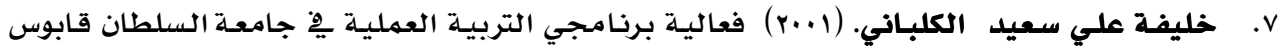

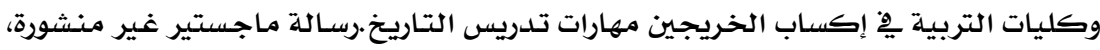

$$
\text { جامعة السلطان قابوس. }
$$

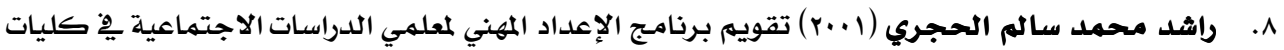

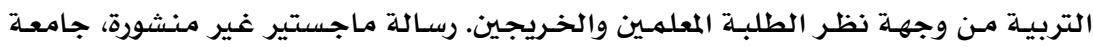

$$
\text { السلطان قابوس. }
$$

9 9. رشدي أحمد طعيمة (1997) . المعله: كفاياته، إعداده تدرييه. دار الفكر العربي: القاهرة.

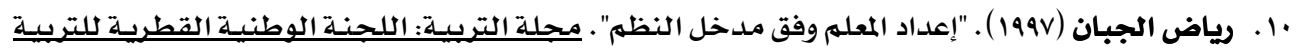

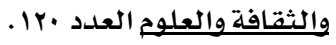

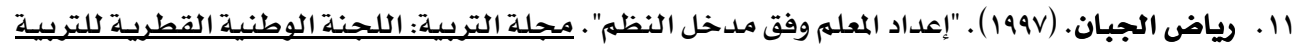

$$
\text { والثقافة والعلوح العدد . 1r. }
$$

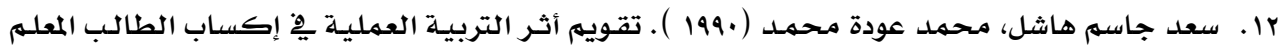
الكفايات التعليمية. مجلة جامعة الكويت، الكويت.

با. . سعد محمد الحريقي (1999) . "فاعلية الإعداد التربوي يِ الموقف المهني للمعلمين والمعلمات قبل التخرج".

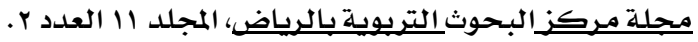




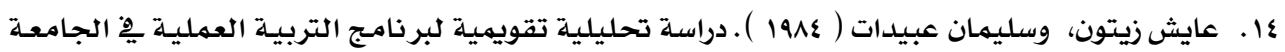

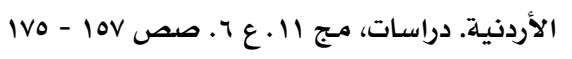

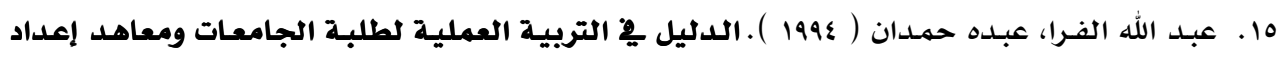
المعلمـين، بيروت، دار الندى للطباعة والنشر والتوزيع.

17 . عرفات عبد العزيز سلهـان (1991) ـ المعلهم والتربية، مكتبـة الانجلو المصرية، القاهرة.

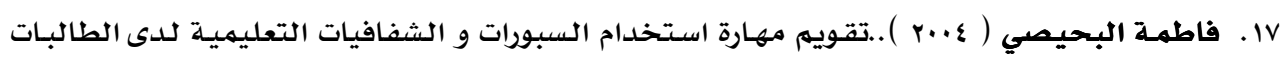
المتدربات تخصص لغة عربية يِّ جامعات غزة" ، رسالة ماجستير غير منشورة، كلية التربية،

$$
\text { الجامعة الإسـلامية. }
$$

1 . ماجد محمد الخطايبة . ( . . ) ). أدوار معلمي اللغة الإنجليزية المتعاونين من وجهة نظر طلبة التربية

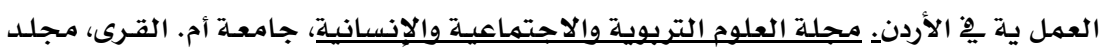

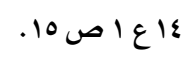

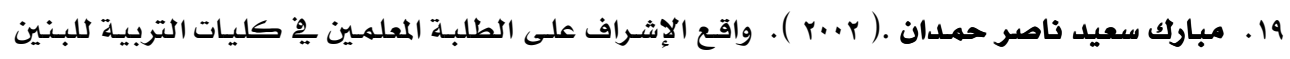

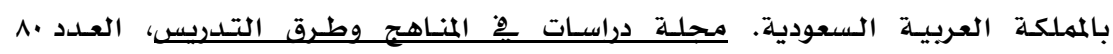

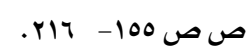

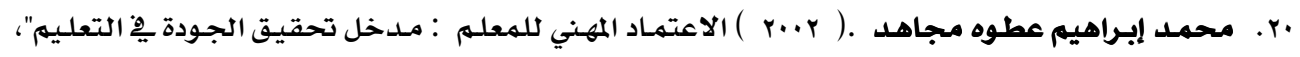

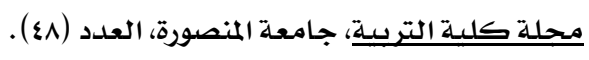

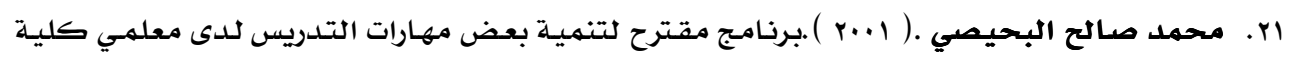
فلسطين التقنية، رسالة ماجستير غير منشورة، جامعة عين شمس و وكلية التربية الحكومية،

$$
\text { برنامجج الدراسات العليا المشترك. }
$$

rr. . محمــد عـادل أحمـلـ (1910) . تقـويهم بعـض المـواد التربويـة بكليـات التربيـة مـن خـلال أداء طـلاب التربيـة العملية لمهارات مهنـة التدريس. رسالة دكتوراه غير منشورة، جامعة الزقازيق.

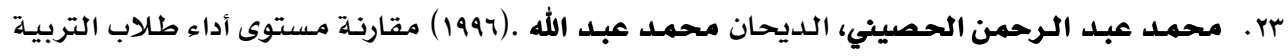

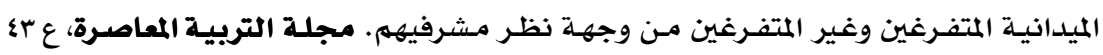

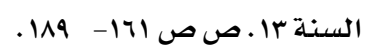

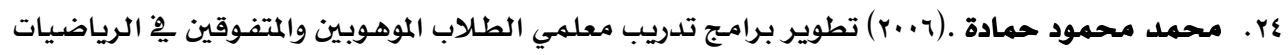
بالمرحلة الثانوية يِ ضوء احتياجاتهم التدريبية و المستويات المعيارية العالمية للمعلهم ، مجله

$$
\text { كلية التربية، جامعة حلوان، العلدد (.r). }
$$

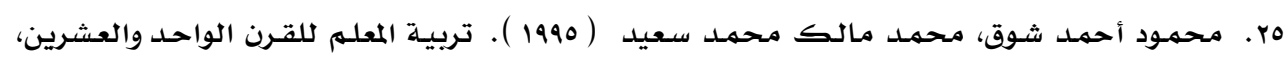

$$
\text { الرياض، مكتبـة العبيكان. }
$$

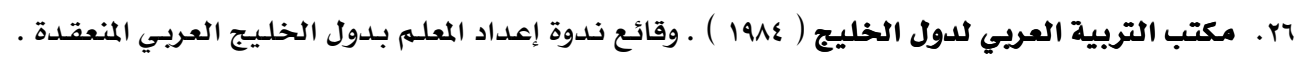

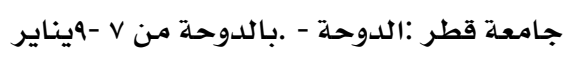




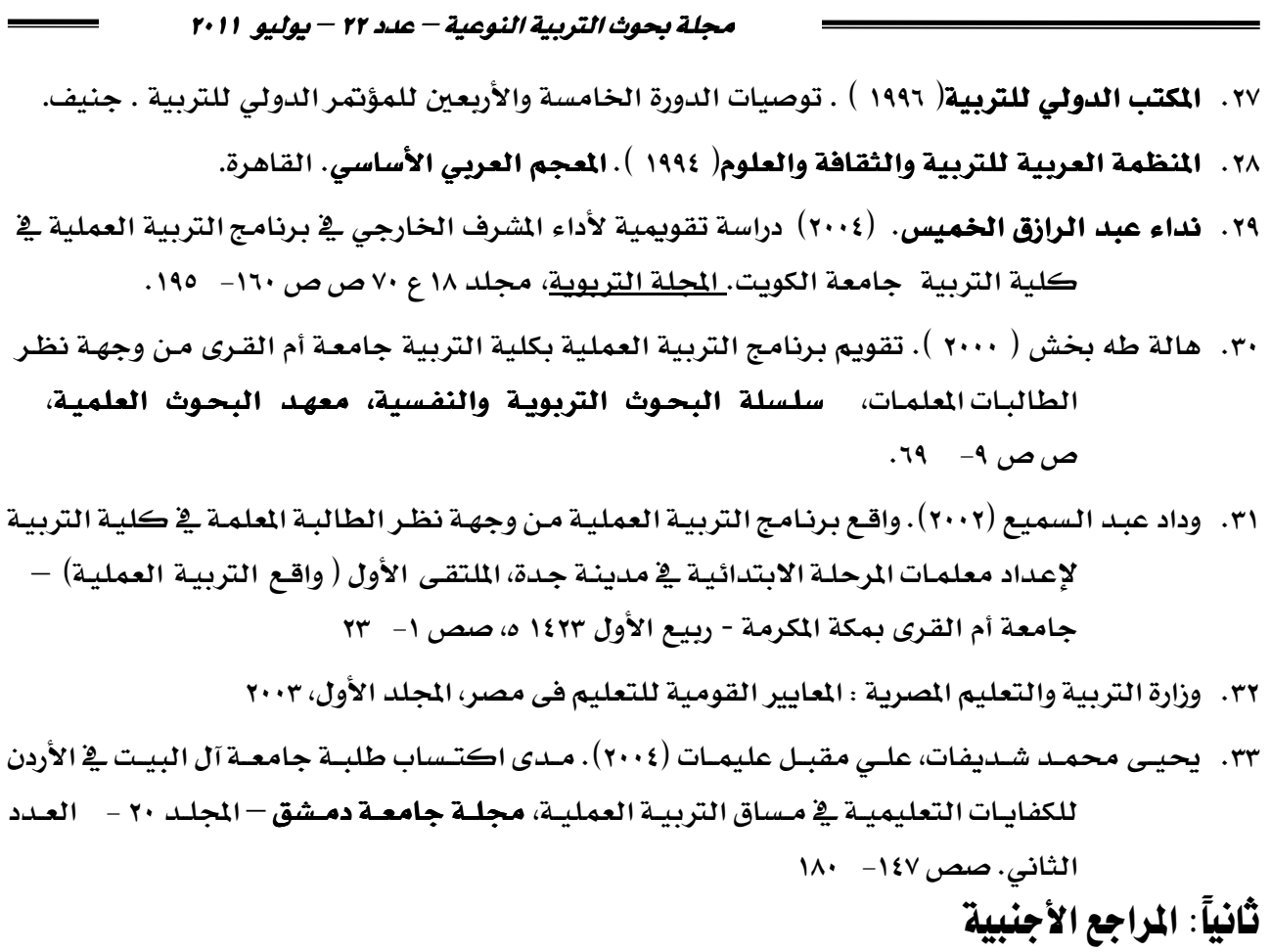

34. Altan, M.Z. \& Trombly, C. (2001). Creating a Learner-Centered Teacher Education Program. English Teaching Forum, vol. 39, No. 3.

35. American Council on the Teaching of Foreign Languages (ACTFL). (2002) "Program Standards for the Preparation of Foreign Language Teachers (Initial Level-undergraduate \& graduate. Available at http://www.actfl.org/files/public/ACTFLNCATEStandardsRevise d713.pdf). Retrieved on 10/102006.

36. Arizona Faculties Council (AFC) (2002). Definition of Learner-Centered Education. Available at: http://www.abor.asu.edu/4_special_ programs/lce/afc-defined_lce.ht m. Retrieved on: June 11, 2010.

37. Barr, R. B. \& Tagg, J. (1995). From Teaching to Learning - a New Paradigm for Undergraduate Education. Change, 27(6), 13-25.

38. Barr, R. B. \& Tagg, J. (1995). From Teaching to Learning - a New Paradigm for Undergraduate Education. Change, 27(6), 13-25.

39. Beck, C. \& Kosnik, C. (2000). Components of a Good Practicum Placement: Student Teacher Perceptions. Teacher Education Quarterly, Spring 2002, 81-98.

40. Beck, C. \& Kosnik, C. (2000). Associate teachers in preservice education: Clarifying and enhancing their role. Journal of Education for Teaching, 26(3), 207-224. 
41. Bender, B. (2003). Student-Centered Learning: A Personal Journal. Educause Center for Applied Research, Research Bulletin, No. 11.

42. Borman, G.D., \& Kimball, S. (2005). Teacher Quality and Educational Equality: Do Teachers with Higher Standards-Based Evaluation Ratings Close Student Achievement Gaps? Elementary School Journal, 106, 3-20.

43. Brown, K.L. (2003). From Teacher-Centered to Learner-Centered Curriculum: Improving Learning in Diverse Classrooms; Education, vol. 124, No. 1.

44. Chou, C. (2004). A Model of Learner-Centered Computer-Mediated Interaction for Collaborative Distance Education. International Journal of E-Learning, 3(1), 11.

45. Doyle, T. (2007) The Role of the Teacher in a Learner-Centered Classroom, Available at: http://www.ferris.edu/htmls/academics/ center/Teaching_and_Learning_Tips/Learner-Centered\%20 Teaching/ Role of Teacher.html. Retrieved on Sept.22, 2010.

46. Ertmer, P., Lehman, J., Park, S., Cramer, J. \& Grove, K. (2003). Adoption and Use of Technology-Supported Learner-Centered Pedagogies: Barriers to Teachers' Implementation. In D. Lassner \& C. McNaught (Eds.), Proceedings of World Conference on Educational Multimedia, Hypermedia and Telecommunications 2003.

47. Flint, W. (2010). Problem-Based Learning: A Learner-Centered Teaching Model for Community Colleges. A Paper Presented in the (2010) annual Meeting of The American Association of Colleges and Universities.

Available at: http://www.aacu.org/meetings/pdfs/problembasedlearning.pdf. Retrieved on: July 22, 2010.

48. Flores, A. H. (2010). Learning Mathematics, Doing Mathematics: A Learner-Centered Teaching Model. Educ. Matem. Pesq., São Paulo, Vol. 12, No. 1.

49. Glickman, C. \& Bey, T. (1990). Supervision. In W.R. Houston (Ed.), Handbook of research on teacher education. New York: Macmillan, 549-566.

50. Grove, Karen J \& Strudler, Neal ( 2001). Cooperating Teacher Practice in Mentoring Student Teacher Toward Technology Use. http://www.unlv.edu/projects/THREAD/docfiles/grant/articles/doc s/Grove-Strudler-NECC03.pdf

51. Grunert, J. (2000). The Course Syllabus: a Learning-Centered Approach. Bolton, MA: Anchor Publishing. 
52. Hadjerrouit, S. (2008). Using a Learner-Centered Approach to Teach ICT in Secondary Schools: An Exploratory Study; Issues in Informing Science and Information Technology, University of Agder, Kristiansand, Norway. Volume 5.

53. Hewett, S. M. (2003). Learner-Centered Teacher Preparation: A Mastery of Skills. Education, Vol. 12, No 1.

54. Huba, M. E. \& Freed, J. (2000). Learner-Centered Assessment on College Campuses: Shifting the Focus From Teaching to Learning. Needham Heights, MA: Allyn \& Bacon.

55. Jeffrey, H. D. (2009). Learner-Centered Instruction Theoretical Roots, Quantitative Research, and Practical Applications. Universit Wien Universität. Available at: http://ctl.univie.ac.at/fileadmin/user upload/elearning/LearnerCentered_Instruction Building_Relationships1 03.07.2009.pdf. Retreived on: Sept, 20, 2010.

56. Keengwe, J.; Onchwari, G. \& Onchwari, J. (2009). Technology and Student Learning: Toward a Learner-Centered Teaching Model. AACE Journal, vol. 17, No. 1.

57. Kilic A. (2010). Learner-Centered Micro Teaching in Teacher Education. International Journal of Instruction January. Vol. 3, No.1

58. Kippel, G. (1975). Information Feedback Need for Achievement and Relation, Journal of Educational Research. 86 (7) 256-261.

59. Kyriacou , Chris \& Stephens Paul (1999). Student Teachers Concerns During Teaching Practice. Education \& Research in Education, 13(1), 18 - 31 .

60. Liu R.; Qiao X.\& Liu Y (2007). A Paradigm Shift of Learner-centered Teaching style: Reality or Illusion? Arizona Working Papers in SLAT (3). Available at: http://www.coh.arizona.edu/awp/ AWP13. Retrieved on, Sept 22, 2010.

61. Ludmerer, K.M. (2004). Learner-Centered Medical Education. The New England Journal of Medicine, Vol. 351 No. 12.

62. McCloskey, M.L., Thornton, B., El Naggar, Z, Touba, N., Mohasseb, M., \& Ghanim, E. (2003) "Home-Grown, Home-Owned Standards for Teachers at Pre-service". Paper presented at the 32nd TESOL Convention, Baltimore, Maryland March 25-29.

63. Mccombs B. \& Vakili D. (2005). A Learner-Centered Framework for ELearning. Idaho Digital Learning Academy, Teachers College, Columbia University. Teachers College Record Vol. 107, No. 8.

64. McCombs, B. L. \& Whisler, J. S. (1997). The Learner-Centered Classroom and School: Strategies for Increasing Student Motivation and Achievement. San Francisco: Jossey-Bass. 
65. McIntyre, J., Byrd, D., \& Foxx, S. (1996). Field and laboratory experiences. In J. Sikula (Ed.), Handbook of research on teacher education. New York: Macmillan,171-193.

66. Meijer, Paulien , Zanting, Anneke \& Verloop. Nico (2002). Practical knowledge, Tools, Suggestions and Significance. Journal of Teacher Education, 53(5) ,406-419.

67. Mohasseb, M.M. and Hakami, I.H. , (2008) A Standard-Based Evaluation of Some Aspects of Performance of Saudi Prospective English Language Teachers. Studies in Curricula and Instruction (Journal of the Egyptian Council For Curricula and Instruction), No. 130.

68. Morton, J.B (2005). "Professional Education Personnel Evaluation Program of Alabama: Teacher System Evaluation Manual, Alabama". (Available at http://www.alabamapepe.com/teacher/altchrmnl605.pdf).

\section{Retrieved on 10/10/2006}

69. NCATE, NCATE 2000 Standards. Washington, DC Author: Available on NCATE's Web site, www.ncate.org. (2000).

70. NCATE (2001). Standards for professional Development Schools USA. (ERIC Document Reproduction Service No ED 013-786).

71. Norman D.A. \& Spohrer J.C. (1996). Learner-Centered Education, Communications of the ACM. Vol. 39, No. 4

72. Normandy, E. (2009). Learner-Centered Teaching. Teaching and Learning Center. University of North Carolina at Pembroke, NC

73. O'Banion, T. (1997). A Learning College for the 21st Century. Phoenix: ACE/Oryx Press.

74. Odden, A.R. (2003). "An Early Assessment of Comprehensive Teacher Compensation Change Plans". In D. Monk and M. Plecki, (Eds.) School Finance and Teacher Quality: Exploring the Connections. Annual Yearbook of the American Education Finance Association. Philadelphia: Eye on Education.

75. Ohashi, J. \& Ohashi, H. (1993). Designing Tasks for Learner-Centered Teaching Suggestions for Meaningful Tasks. Japanese-Language Education Around the Globe, Japanese Language Institute Vol. 3.

76. Ohio Department of Education (2003) : Academic Content Standards K12 Technology, Center for Curriculum and Assessment Office of Curriculum and Instruction. Available at:http://www.ode.state.oh.us/GD/DocumentManagement/Docum entDownload.aspx? DocumentID=793

77. Orchard, P. (2007). An Examination of Learner-Centered Professional Development for Reluctant Teachers. Unpublished $\mathrm{PhD}$ Dissertation, University of Missouri, Columbia. 
78. Randall, M. and Thronton B (2001). Advising and Supporting Teachers, Cambridge, (UK) Cambridge University Press

79. Sánchez-Contreras, L.; Gmez, R.M.; Ramos, J.; Flores, B. C. \& Knaust, H. (2002). Developing a Learner-Centered Environment to Meet the Needs of a Growing Urban Commuter Student Population. Proceedings of the American Society for Engineering Education Annual Conference \& Exposition.

80. Snell, J.L. (2000). "The Liminal Tension of Performance Evaluation for Pre-service Teacher Educators: A Mechanism for Accountability or a Tool for Growth?". Paper presented at the 52nd Annual Meeting of the American Association of Colleges for Teacher Education, Chicago, IL, February 26-29.

81. Stroh, H. R. \& Sink Ch. A. (2002). Applying APA's Learner-Centered Principles to School-Based Group Counseling - General Features American Psychological Association, Professional School Counseling.

82. Tudor, I. (1993) Teacher Roles in the Learner-Centred, Classroom. ELT Journal, Vol. 47, No. 1.

83. Uribe, E. (2008). Learner Centered Principles in Distance Education Available at: http://itec.sfsu.edu/wp/860wp/F05_860_uribe.pdf. Retrieved on July 22, 2010.

84. Ware, H.B. (2006). Learner-Centered E-Learning: an Exploration of Learner-Centered Practices in Online and Traditional Instruction in Higher Education; Unpublished PhD Dissertation, Louisiana State University; Agricultural and Mechanical College.

85. Weimer, M. G. (2002). Learner-Centered Teaching: FIVE Key Changes to Practice. San Francisco: Jossey-Bass.

86. Wiggins, H. L. (2004). A Learner-Centered And Participatory Approach to Teaching Community Adult ESL, Unpublished MA Thesis, Brigham Young University.

87. Wohlfarth, D; Sheras, D.; Bennett, J. L.; Simon, B.; Pimentel J. H. \& Gabel L. E. (2008). Student Perceptions of Learner-Centered Teaching. InSight: A Journal of Scholarly Teaching, Volume 3. 